Sanat Tarihi Dergisi

Cilt/Volume: XXIV, Sayl/Number:2

Ekim/October 2015, 175-226

\title{
ISA'NIN DOĞUMU
}

M. Sacit PEKAK ${ }^{1}$-Durmuş GÜR ${ }^{2}$

\section{Özet}

Çalışma kapsamında, İsa'nın doğumu, tarihsel süreçteki benzer doğum örnekleri ile ikonografik-üslup açısından incelenmiş, doğum tasvirinin görüldüğü Kappadokia kiliseleri, Anadolu'daki bazı kiliselerdeki duvar resimleri, Avrupa örnekleri ve çeşitli müzelerdeki madeni ve taş-mermer eserler, konu benzerliği, üslup, teknik ve kompozisyon açısından değerlendirilmiştir.

Çalışma kapsamında İsa'nın doğumu, apokrif ve kanonik kaynaklar ışı̆̆ında zaman, mekan ve yer belirtilerek incelenmiş, kompozisyonlardaki figür çoğunluğu ve figürlerin sahne içindeki konumları kronolojik olarak incelenmiştir.

\section{Anahtar Kelimeler}

İsa, Mesih, Meryem, Kanonik, Apokrif, Doğum, Salome.

\section{Abstract}

\section{The Birth of Jesus}

Within the scope of the study, the Birth of Jesus Christ was examined and it was evaluated in terms of the Cappadocia Churches where the cribs of Jesus Christ were depicted, the wall murals in some churches in Anatolia, European samples and metallic and stone-marble works in several museums, similarity of the subject similarity, genre, technique and composition.

Within the scope of the study, the Birth of the Jesus Christ was examined within the light of apocryphal and kanonical sources by specifying time, space and place, the figure majority in the compositions and the positions of the figures inside the scene were evaluated chronogically.

\section{Keywords}

Jesus, Messiah, Virgin Mary, Canonical, Apocryphal, Birth, Salome.

\footnotetext{
${ }^{1}$ Hacettepe Üniversitesi Edebiyat Fakültesi Sanat Tarihi Bölümü, Prof. Dr. M. Sacit PEKAK. sacitpekak@gmail.com

${ }^{2}$ Karabük Üniversitesi Edebiyat Fakültesi Sanat Tarihi Bölümü, Bizans Sanatı Anabilim Dalı, Arş. Gör. Durmuş GÜR. durmusgur@gmail.com

Yardımlarından dolayı değerli meslektaşımız Yrd. Doç. Dr. Hasan Uçar’a teşekkür ederiz.
} 


\section{Sacit Pekak-Durmuş Gür}

\section{GíRiş}

İsa'nın doğumu, Kappadokia kiliseleri başta olmak üzere Anadolu ve yakın çevredeki Hıristiyan Dönemi yapıları, Anadolu çevresindeki kiliselerin duvar resimleri ve çeşitli el sanatlarında yaygın şekilde tasvir edilen bir konudur. Çalışmada İsa'nın doğumunun betimlendiği eserler ve duvar resimleri incelenmiştir.

İsa'nın doğumunun kanonik ve apokrif kaynaklarda çeşitli farklılıklarla anlatıldığg fakat duvar resimlerinde ve küçük el sanatlarında ortak bir dilin tercih edildiği (tasvir ve ikonografik değerlendirmeler sonucunda) küçük farklılıklarla görülür ${ }^{3}$. İsa'nın doğumu somut veriler 1şı̆̆ında karşılaştırmalı olarak Buda, İskender, Dionysos ve Akkhilleus'un doğumu ile çeşitli açılardan benzerdir. Bu benzerlikler özellikle Dionysos ve Budda ile hikaye; İskender ve Akkhilleus ile de tasvir açısından benzerdir. Çalışma kapsamında tespit edilen eserler bunun göstergesidir.

İsa'nın doğumu, “Meryem'in doğumu, Meryem'in nişanlanmasl, Meryem'e müjde, Meryem'in hamileliği ve Elizabeth 'i ziyareti, Yusuf'un düşü ve Yusuf'a Meleğin görünmesi, nüfus sayımı (Quirinius Sayımı), İsa'nın doğumu, Kral Hirodes'in düşünü yorumlatması, Çobanların tapınması ve Müneccim Krallar'ın tapınması” gibi konular sırasıyla alt başlıklar halinde incelenmiştir.

\section{Meryem'in Doğumu}

Matta, İsa'nın Çocukluk İncili ve Iokabos'un Protoevangeliumu'nda Meryem hakkında çeşitli bilgiler yer almaktadır. Meryem'in doğumu, çocukluğu ve devam eden bakireliği Iokabos'un Protoevangelionu'nda ayrıntılı şekilde anlatılmaktadır (Cartlidge ve Elliott, 2001: 32; Carr ve Kazdhan, 1991: 1744-1745; Carr, 1991: 2174-2175; Jaszai, 1994:120-125).

Meryem'in Doğumu İncili'nde Meryem'in doğumuna ve evliliğine ilişkin çeşitli bilgiler yer almaktadır. Meryem'in Çocukluk İncili'ne göre Meryem'in babası Joachim ve annesi Anna'nın çocukları olduğu, Nasıra'da doğduktan sonra Kudüs'e getirildiği anlatılmaktadır. Joachim, Celile ve Nasıra soyundan Anna ise Bethlehemli olarak ifade edilmiştir (Meryem'in Doğumu İncili, 1).

Yeni Ahit'e göre Meryem, Joachim ve Anna'nın çocuğudur. Meryem'in doğumu on iki bayramdan biri olarak kabul edilir (1-8 Eylül). Meryem'de tıpkı diğer tüm ölümlülerin doğduğu gibi Anna ve Joachim'den dünyaya gelir. Roma Katolik dogmalarına göre "lekesiz doğum", Doğu Kilisesi tarafından kabul edilmemektedir. Anna'nın, Meryem'den önce herhangi bir çocuğu olmadığı bilinir. Tanrı'ya dua eder (tıpkı İbrahim'in (Abraham) karısı Sara gibi) ve çok yaşlı olmasına rağmen melek

\footnotetext{
3 Apokrif kaynaklar için bakınız: http://www.theworkofgod.org/Aparitns/PevglJms.htm 02.03.2016-02:21
} 
tarafindan müjdelenerek hamile kalacağı belirtilir (böylece Meryem'in doğumu gerçekleşir) $^{4}$ (Spitzing, 1989: 129).

Meryem'e Müjde sahnesi, Bakire Meryem'in Kutsal Ruh ile hamile kalmasını

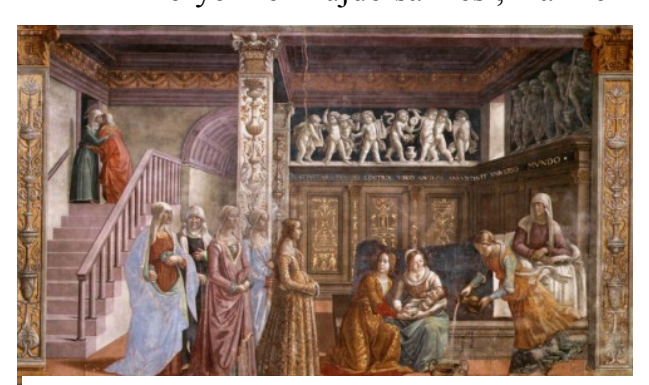

Resim 1. Domenico Ghirlandaio, Meryem' in Doğuşu, Floransa Santa Maria Novella Kilisesi, 1491 (Gombrich, 1980: 229) anlatır ${ }^{5}$. Meryem siklusu içinde incelenen doğum, aynı zamanda İsa'nın hayat siklusunun da başlangıcı olarak kabul edilir. Bizans sanatında Koimesis Meryem yaygın bir şekilde tasvir edilir. Avrupa'da, Meryem'in yaşamından sahneleri çeşitli sanat eserlerinde görmek mümkündür (Sach, Badstübner ve Neumann, 1988: 143).

15. yüzyıl sonrasında resmedilen

Meryem'in doğumu bir evde gerçekleşir. Tasvirlerde Anna ve Joachim yaşlı olarak betimlenmiştir. Tasvirlerde çeşitli kadınları Anna'ya hizmet ederken görmek mümkündür (Sach, Badstübner ve Neumann, 1988: 143) (Resim 1-2).

Doğum sonrası betimlerde Anna, parlak kırmızı maphorion giyimli, bir yatağa uzanmış ya da otururken resmedilmiştir. Anna'nın eşi Joachim, yeni doğan çocuğu yıkanmak için bir ebe çağırmıştır. Joachim, tasvirlerde yer aldığı kadarıyla bir elinde Anna'ya mum tutarken görülür (Spitzing, 1989: 129). $\begin{array}{ccc}\text { Meryem'in } & \text { doğumu } & \text { konulu } \\ \text { tasvirlerde yukarıdan } & \text { aşağıya } & \text { (olayın }\end{array}$ gerçekleştiği anı yansıtmaktadır) meleklerin inişinin resmedildiği görülür. 1514 tarihli Andrea del Sarto buna güzel bir örnektir (Sach, Badstübner ve Neumann, 1988: 143).

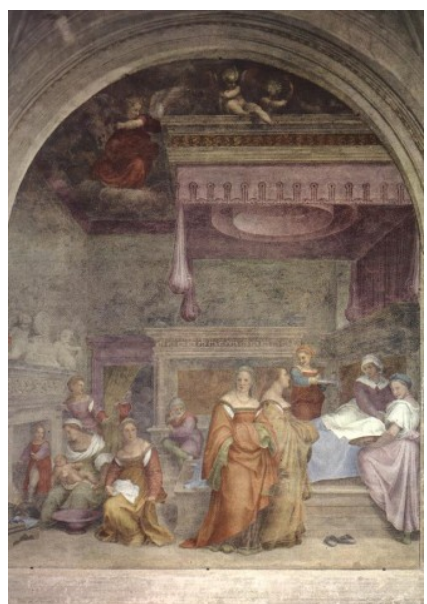

Resim 2. Meryem'in Doğumu, Andrea del Sarto, Floransa Santissima Annunziata, 1514

(Crowe ve Cavalcaselle, 1914: 172)

\section{Meryem'in Nişanlanması}

Apokrif ve kanonik kaynaklarda soy kaydı atalarının üzerinden ifade edilir.

\footnotetext{
${ }^{4}$ Bizans kiliselerindeki Gabriel-Başmelek kavramı için bakınız; (Doğan, 2010: 171-184).

5 4-18.yüzyıl arasına tarihlendirilen Meryem'in doğumu tasvirleri için bakınız; (Jaszai, 1994:121 124).
} 


\section{Sacit Pekak-Durmuş Gür}

İsa'nın soy kaydı, Matta'da şöyle anlatılır;

“İbrahim oğlu, Davut oğlu İsa'nın soy kaydı şöyledir: İbrahim İshak'ın babasıydl, İshak Yakup’un babaslydl, Yakup Yahuda ve kardeşlerinin babasıydı (Matta 1: 1-2). Yakup Meryem'in kocası Yusuf'un babaslydı. Meryem'den Mesih diye tanınan İsa doğdu (Matta 1: 16) ${ }^{6}$.

Meryem'in Doğumu İncili'nde Meryem'in nişanına yer verilmiştir. İncile göre Davut soyundan olan Yusuf, yaşlı ve dürüst bir adam olarak ifade edilir. Meryem'le nişanlanmak isteyenler tapınaktaki Rahibe kuru ağaç dalları sunmuşlar. Bütün insanların arasında bir tek ağaç dalı farklıdır ve o da Yusuf'un dalıdır. Tapınağa sunulan Yusuf'un ağacı üzerine Tanrı'nın huzurundan gelen bir güvercin konmuş, böylece Yusuf'un temiz ve bakire olduğu anlaşılmıştır. Bunun üzerine seçilmiş kişinin Yusuf olduğuna inanılmış ve Meryem ile evlenmeye hak kazanmıştır. Meryem ile nişanlanabileceğine karar verildikten sonra Yusuf, gerekli işlem hazırlıkları için Bethlehem'e dönmüş Meryem ise Celile'ye ailesinin yanına gitmiştir (Meryem'in Doğumu İncili, 9). Bu uygulama günümüzde de olduğu gibi evlilik öncesi ayrı konaklama ve evlilik sonrasında ayrı yaşam alanları hakkında çeşitli bilgiler sunar. Ayrıca nişan öncesi ayrı alanlarda yer aldıkları anlatılarak Meryem'in bekareti vurgulanmıştır.

\section{Meryem'e Müjde}

Erken dönemden itibaren İsa'nın doğumunu konu alan tasvirlerin, kiliseler litürjik eşyalar, ikonalar ve el yazmaları başta olmak üzere birçok alanda işlenmiştir. Örneklerde Yeni Ahit’teki tasvirlerden yola çıkılarak mekanın neresi olabileceği saptanmaya çalışılmıştır. Bu çalışmalar doğrultusunda Meryem'in doğum yaptığı mekanın han, ahır ya da bir mağara olabileceği düşünülmektedir. Meryem'in doğumu öncesinde Meryem'e Müjde konusuna bakmak gerekir. Meryem'e Müjde on iki bayramdan biri olarak kabul edilir ve Ortodoks Kilisesi takvimine göre, Batı'da 25

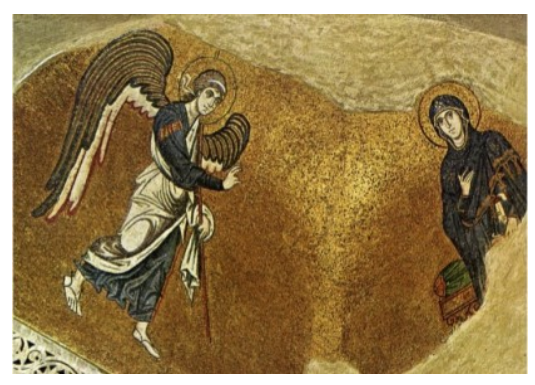

Resim 3. Meryem'e Müjde, Yunanistan Hosios Loukas Kilisesi (Hannah Vickers, Pin it Arşivi) Mart'ta, İsa'nın doğumundan dokuz ay önce kutlanır (Önen-Alev, 2014: 30).

Bayram, ilk olarak 431 Efes Konsili (Ephesus) kararları sonucunda kutlanmaya başlanılmıştır. Luka'da Meryem'e müjde konusunda ayrıntılara yer verilmemiştir. Müjde tasvirlerinde görülen kirmen, kuyu, testi ve yün gibi ikonografik öğeler Iokabos'un Protoevangelionu'nda karşımıza çıkmaktadır. Iokabos'un Protoevangelionu'na göre melek Meryem'i iki defa (Meryem'e kuyu başında seslenmesi ve Meryem'in evinde görünmesi)

\footnotetext{
${ }^{6}$ Mesih-Mesihçiler: Mesih sözcüğ̈̈nden türetilen bu lakap Grekçe'de "Hristianos" olarak geçmektedir (Elçilerin İşleri, 11: 25-26).
} 
müjdelemiştir (Resim 3). Bu olay şöyle anlatılır;

"ve (Meryem) testiyi aldı ve su doldurmak için dışarı çıktı. Ve gördü, bir ses dedi ki: Sen Tanrı'nın sevgili kulusun; Tanrı seninledir; kadınlar arasında kutsanmış olan sensin! Ve (Meryem) sesin nereden geldiğini görmek için etrafina baktı. Ve korkarak evine gitti, testiyi yere biraktı, eline moru (yün) ald, yerine oturdu ve (yünü kirmen ile) eğirmeye başladl. Ve gördü, önünde Tanrı'ın meleği duruyordu ve dedi: Korkma Meryem!..." (Iokabos'un Protoevangelionu, 9: 7 - 9).

Meryem'in Çocukluk İncili'nde Meryem'in, nişan sonrasında evinde Tanrı'nın meleği tarafından müjdelendiği anlatılır. Ayrıca burada diğer kaynaklardan farklı olarak Meryem'in bir oda içinde ve büyük bir 1şık eşliğinde Tanrı'nın meleği tarafından müjdelendiği anlatılır. Tanrı'nın meleği kutsal ve övücü sözlerinin ardından doğacak çocuğun Tanrı'nın oğlu olacağı ve Yakup soyunda saltanat süreceği söylenmiştir (Meryem'in Doğumu İncili, 9).

Meryem'e müjde konulu tasvirler yaygın bir şekilde betimlenmiştir. Tasvirlerde Meryem ve onu müjedeleyen melek çeşitli kompozisyonlarda görülür. Ayakta olmasının yanında otururken betimlenen Meryem, çoğunlukla tabure, koltuk ve taht üzerinde (Yunanistan Hosios Loukas) (Lazarides, 1987: 44, Fig. 25) üzerinde

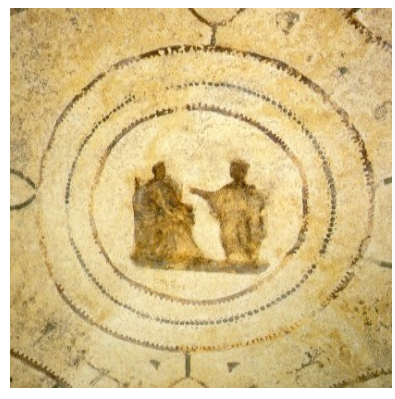

Resim 4. Meryem'e Müjde, Roma Priscilla Katakombu. 4. Yüzv1l

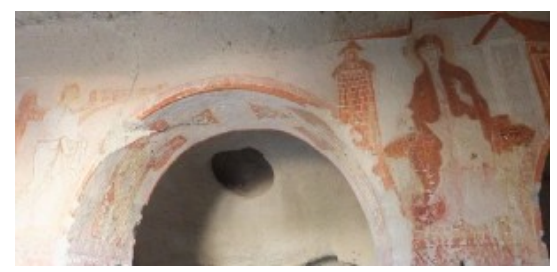
görülür Bazen ayaklarının altında suppedaneum $\mathrm{da}^{7}$ bulunabilir. Genellikle üzerinde bakireliğini simgeleyen maphorionu ${ }^{8}$ bulunmaktadır (Schiller, 1972: 36).

Meryem'e Müjde, Erken Dönem'den itibaren kiliselerde tasvir edilen önemli kompozisyonlar arasında yer almaktadır. Meryem'e müjde tasvirinin bilinen en erken tarihli olanı 4. yüzyıl başlarına tarihlendirilen Roma Priscilla Katakombu'nda yer alır. Roma Santa Maria Maggiore zafer kemerinde görülen tasvir, Efes

Konsili'nden hemen sonra Papa III. Sixtus (432440) tarafından yaptırılmıştır. Burada sahnenin solunda tapınağı andıran bir yapı bulunur ve Meryem tahtta oturur. Rabula İncili'nde (4a) Meryem ayakta tasvir edilmiştir (Tanburoğlu, 2001: 114) (Resim 4).

Resim 5. Meryem'e Müjde, Saklı Kilise, 10.-11. Yüzyıl (Pekak Arşivi-2015)

\footnotetext{
${ }^{7}$ Suppedaneum, yönetici ya da dini liderleri diğerlerinden ayırmak için ayaklarının altına yerleştirilen sekilere verilen addır.

${ }^{8}$ Maphorion için bakınız (Kazhdan ve Sevcenko, 1991: 1294).
} 


\section{Sacit Pekak-Durmuş Gür}

Meryem, müjde tasvirlerinde çoğunlukla evinin önünde görülür. Ev, iki sütunun taşıdığı kemerli yapı ya da tapınak şeklindedir. Meryem sağ eliyle Meleği karşılarken sol elinde çoğunlukla kirmen tutar. Palermo Chapella Palatina, Kappadokia Saklı Kilise ve Gümüşler Kilise'de Meryem'e müjde tasvirleri görülür (Resim 5). Kappadokia'da toplam otuz üç kilisede Meryem'e müjde sahnesi bulunur ve bunlardan yarısına yakını Göreme kiliselerindedir' (Restle, 1967: Book, 1,2,3).

\section{Meryem'in Hamileliği ve Elizabeth'i Ziyareti}

Müjdelendikten sonra hamile kalan Meryem bir süre sonra Yahudiye şehrindeki Zekeriya'nın evinde Elizabet'i ziyaret eder. Bu dönemde Elizabeth'de hamiledir. Gabriel tıpkı İsa'nın doğumu gibi Vaftizci Yahya'nın da doğumunu müjdelenmiştir (Doğan, 2010: 172). Elizabet, Meryem'in selamını aldığında karnındaki bebek, doğmamış İsa'ya yönelir. Bu karşılaşma Luka'da şöyle anlatılır;

“Ey sen mübarek kadın, rahminin ürünü de mübarek olsun! Nasıl oldu da, Rabbimin anasının bana gelmesi bana bağlşlandı? Meryem, şöyle cevaplar; Hep Rabbi yüceltir yüreğim ve sevinir ruhum Tanrl'da, Kurtarıcı'da çünkü, kulunun hiçliğine bakışlarını çevirdi O. Ve işte şimdiden sonra artık, mutlu sayacak beni bütün kuşaklar." Meryem, Elizabet'le üç ay kadar kalarak evine döner (Luka, 1: 39-56).

Iokabos Protoevangelionu'nda Meryem'in Elizabeth'i ziyareti ve diğer ayrıntılarla birlikte şöyle anlatılmaktadır;

“Ve Meryem büyük haber ile akrabası Elizabet'e gitti ve kapıyı çaldı. Ve Elizabet Meryem'i duyduğunda elindeki alı (yün) bıraktı ve kapıya koştu, kapıyı açtı; ve onu kutsadı...(Meryem) üç ay Elizabet ile kaldı; günden güne karnı büyüdü. Ve Meryem korkmaya başladı, kendi evine gitti ve kendini İsrailoğulları'ndan sakladı. Ve bu mucizeler olduğunda (Meryem) on altı yaşındaydl”" (Iokabos'un Protoevangelionu, 9: 15-20).

Orta Bizans Dönemi (842-1204) tasvirlerinde Meryem ve Elizabeth karşılaşması çeşitli şekillerde tasvir edilmiştir. Meryem ve Elizabeth, buluşmalarında konuşur ya da kucaklaşırken tasvir edilmiştir (Taft ve Carr, 1991: 180). Elizabet'in Meryem'in karnına dokunması ve Elizabet'in evinin önünde ellerini Meryem'e doğru

\footnotetext{
${ }^{9}$ Kappdokia Bölgesi, İsa'nın doğumu tasvirleri için bakınız;

Çavuşin Ioannes Prodromos Kilisesi (10. yüzyıl), Göreme Karanlık Kilise (11. yüzyıl), Tağar Aziz Theodoros Kilisesi(11. yüzyı1), Göreme El Nazar Kilisesi(10. yüzyıl), Ihlara Kokar Kilise, İsa'nın doğumu, (9.-11. yüzyıl), Soğanlı Karabaş Kilisesi (11. yüzyıl), Niğde Eski Gümüş Manastırı (12.-13 yüzyıl), Göreme Elmalı Kilise (11. yüzyıl), Avcılar Sarnıç Kilise (11. yüzyıl), Göreme Saklı Kilise (11. yüzyıl), Göreme Yeni Tokalı Kilise (10.yüzyıl), Göreme Elmalı Kilise (11. yüzyıl), Göreme Karanlık Kilise (11. yüzyıl), Göreme Çarıklı Kilise (11. yüzyıl),Kılıçlar Kuşluk Kilise (11. yüzyıl), Tağar Aziz Theodoros Kilise (11. yüzyıl), Soğanlı Karabaş Kilise (11. yüzyıl), Ihlara Kokar Kilise (9.-11. yüzyıl), Ihlara Pürenli Seki Kilise (11. yüzyı1), Ihlara Bahattin Samanlığı Kilise (9.-11. yüzyıl) (Restle, 1967: Book I-II-III; Coşkuner, 2009).
} 
uzatarak onu kutsal sayması Luka ve Iokabos'un Protoevangelionu'na uygundur (Schiller, 1971: 54).

Meryem'in Çocukluk İncili’nde, Meryem'in hamileliği ve Yusuf'a meleğin görünmesi anlatılır. Doğumun gerçekleştiği mekan ve zaman hakkında herhangi bir bilgi sunulmayan kaynakta, Meryem'in doğuracağı çocuğun adının İsa olacağı, melek tarafından Yusuf'a iletilir (Meryem'in Doğumu İncili, 10).

\title{
Yusuf'un Düşü ve Yusuf'a Meleğin Görünmesi
}

Meryem'in nişanlısı Yusuf olgun, yaşlı ve dürüst bir adam olarak kabul edilir. Meryem'in hamileliği üzerine Yusuf kuşkulanır ve derin düşüncelere dalar. Yusuf, bu olanları düşünürken, Gabriel Yusuf’a görünür. Matta'da bu olay şöyle anlatılır;

\begin{abstract}
"Meryem, Yusuf'la nişanliydl. Ama birlikte olmalarından önce Meryem 'in Kutsal Ruh'tan gebe olduğu anlaşıldı (Matta, 1: 18). Nişanlısı Yusuf, doğru bir adam olduğu ve onu herkesin önünde utandırmak istemediği için ondan sessizce ayrlmak niyetindeydi (Matta, 1: 19). Ama böyle düşünmesi üzerine Rab'bin bir meleği rüyada ona görünerek şöyle dedi: "Davut oğlu Yusuf, Meryem'i kendine eş olarak almaktan korkma. Çünkü onun rahminde oluşan, Kutsal Ruh'tandır (Matta, 1: 20). Meryem bir oğul doğuracak. Adını İsa koyacaksın. Çünkü halkını günahlarından O kurtaracak. (Matta, 1: 21). Bütün bunlar, Rab'bin peygamber aracılı̆̆lyla bildirdiği şu söz yerine gelsin diye oldu: (Matta, 1: 22). "Işste, kız gebe kalıp bir oğul doğuracak; adını Immanuel koyacaklar. Immanuel, Tanr bizimle demektir (Matta, 1: 23). Yusuf uyanınca Rab'bin meleğinin buyruğuna uydu ve Meryem'i eş olarak yanına aldı (Matta, 1: 24). Ama oğlunu doğuruncaya dek Yusuf ona dokunmadı. Doğan çocuğun adını Ísa koydu (Matta, 1: 25).
\end{abstract}

\section{Nüfus Sayımı (Quirinius Sayımı)}

Meryem'in hamileliği sırasında, imparator Augustus, imparatorluk topraklarında nüfus sayımı için ferman çıkarmıştır. İlk nüfus sayımı olarak kabul edilen işlem Roma topraklarında Quirinius, Suriye kralıyken yapılmıştır. Quirinius Nüfus sayımına göre halk soy kaydının bulunduğu yere giderek sayımlara katılmak zorundadir.

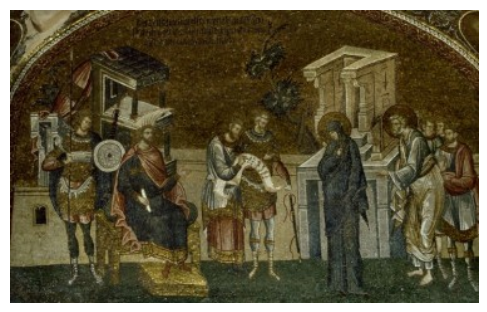

Meryem'in nişanlısı Yusuf, nüfus sayımı için Nasıra'dan Betlehem'e gitmek zorunda kaldı çünkü soy kaydında da anlatıldığı gibi Yusuf, Davut soyundandır. Yusuf, soy kaydının bulunduğu Bethlehem'e giderken nişanlısı Meryem'i de yanında hayvan sırtında götürmüştür (Luka, 2: 2).

Resim 6. Meryem ve Yusuf Nüfus Sayımında, Khora Kilisesi (Pekak Arşivi, 2012) 
Meryem'in hamile olarak betimlendiği tasvirlerde çoğunlukla karnının şişliğine dikkat edilmemiştir. İstanbul Khora Manastırı Kilisesi'nde tasvir edilen Nüfus Sayımı'nda Meryem'in hamile olduğu görülür (Resim 6).

\section{ISSA'NIN DOĞUMU}

Ortodoks Kilise takviminde yortular, Meryem'in doğumuyla (1-8 Eylül) başlar. ikinci yortu, haçın yükselmesi (Stavroproskynesis, 14 Eylül), üçüncü yortu, Meryem'in tapınağa sunuluşu (21 Kasım), dördüncüsü ise İsa’nın doğumudur (25 Aralık) (Spitzing 1987:125). İsa'nın doğum tarihi kaynaklarda belirtilmediği için yortu olarak kutlanacağının kesinleşmesi uzun sürmüştür. İsa'nın doğumu ilk olarak 336 yılında, Batı'da Roma Kilisesi tarafından kutlanmıştır (Spitzing, 1987: 125). Bu uygulama kısa süre içinde diğer kiliseler tarafından benimsenerek uygulanmıştır. Batı Kiliseleri’nde İsa'nın doğumu 25 Aralık, Doğu kiliselerinde ise 6 Ocak olarak kabul edilir (Sach, Badstübner ve Neumann, 1988: 141; Spitzing 1987:125; Taft ve Carr, 1991: 715).

Ermeni ve Rus Ortodoks Kiliseleri, İsa'nın doğumunu 6 Ocak'ta kutlamaya devam eder. 25 Aralık'ın benimsenmesinde Roma'daki Pagan kültürü olan kış gündönümü kutlamasının (Saturnalia Festivali) son gününün 25 Aralık olarak kabul edilmesi etkilidir (Spitzing, 1987: 125).

\section{Dini Kaynaklarda İsa'nın Doğumu (Tablo 7)}

Kanonik ve apokrif kaynaklarda İsa'nın doğumu anlatılmaktadır (WilhelmRed, 1994: 86-87). Luka'da İsa'nın doğumu, kundaklanması ve doğum mekanı şu şekilde anlatılmaktadır;

"ve vaki oldu ki, orada bulunurlarken, doğurmasl günleri geldi. İlk oğlunu doğurdu; kundağa sardı ve onu bir yemliğe yatırd, çünkü handa onlara yer yoktu” (Luka, 2: 6-7).

İsa'nın doğumu tasvirlerinde, merkezde yemlik içinde İsa, yanında ise Meryem ve Yusuf yer alır. Handa yer kalmadığı için İsa, yemlik üzerindebetimlenmiştir. Doğumun ahırda gerçekleştiğini vurgulamak için yemliğin yanında kundağın başında öküz ve eşek gibi kutsal hayvanlar görülür.

Matta'da Luka'ya oranla daha az ayrıntı yer verilmiştir. Matta'da zaman, mekan ve şahıslardan bahsedilmez daha çok Yusuf ve Meryem'in nişanlanması, Meryem'in hamileliği ve Yusuf'a meleğin görünmesi anlatılır (Matta, 1: 18-25).

İsa'nın doğumu hakkında en ayrıntılı bilgi Iokabos'un Protoevangelionu'nda yer alır. Protoevangelion'da Meryem'in Yusuf yardımıyla Bethlehem'e geldiğinde eşekten iner ve doğum işlemleri için mağaraya girdikleri şöyle anlatılır;

“ve Meryem Yusuf'un onu eşekten indirmesini ve doğum vaktinin geldiğini tekrarladı. Ve Yusuf, onu eşekten indirdi. Ve bir mă̆ara buldu ve onu içeri soktu” (Iokabos'un Protoevangelionu, 12: 14). 
Yusuf'un ebe bulmak için Beytüllahim'e giderken oğullarını mağarada, Meryem ile birlikte biraktığı belirtilmektedir (Iokabos'un Protoevangelionu, 13: 1). Iokabos'un Protoevangelionu'ndaki ifadeye bakılarak Yusuf'un daha önceden evlenmiş ve en az iki çocuğunun olduğu düşünülür. Kappadokia Bölgesi Ağaçaltı Kilise'deki kuzey haç kolundaki Mısır'a Kaçış tasvirinde önde giden erkek figürünün Yusuf'un oğlu olarak ifade edilir (Thierry, 1963: 78, Fig. 18). Yusuf, aramaya gittiği ebe kadın ile kısa bir süre sonra mağaraya döner, o sırada mağaranın çevresinde bir 1şık parladığ1 ifade edilir (Iokabos'un Protoevangelionu, 13: 10-11). Yusuf'un getirdiği ebe daha sonra Salome adında başka bir kadını da mağaraya getirmiştir (Iokabos'un Protoevangelionu, 14: 14). Sonradan gelen Salome, Meryem'in bekaretinden şüphe ederek Meryem'in bekaretini kontrol etmek için elini O'nun rahmine uzatır (Iokabos'un Protoevangelionu, 13: 20). Elini uzattığ esnada Salome'nin eli kurur ve ağrılar içinde bağırmaya başlar. Melek, Salome'ye bebek İsa'yı kucağına alarak dua etmesini söyler. Dua ederek İsa'ya dokunan Salome'nin elinin iyileşmesi üzerine Salome, İsa'ya iman eder (Iokabos'un Protoevangelionu, 13: 25).

Pesudo-Matta'da İsa'nın doğumunun mağarada gerçekleştiği şöyle anlatılır;

"Yolculuklart sırasında doğumu gelen Meryem ve Yusuf bir mă̆araya sığınır. Mă̆arada günün altıncı saati gibi büyük bir parlaklık oluşur. Mă̆arada herhangi bir ışık yoktur fakat birden doğan bu ışık tüm alanı aydınlatır. O esnada Melekler de orada yer alarak doğumun acısız ve sancısız bir şekilde gerçekleşmesine yardımcı olmuştur (Pesudo-Matta, 1314). İsa'nın doğumunun gerçekleştiği sırada Yusuf ebe kadınlarl aramak için yola koyulmuştur (Pesudo-Matta, 13). Doğum sırasında mağaranın girişinde görülen ışıktan korkan Yusuf ve ebeler mă̆araya girmekten çekinir. Yusuf geri döndügünde Meryem'e Zelomi ve Salome adında iki ebe bulduğunu söylemiştir (Pesudo-Matta, 13-14). Yusuf, ebelerin koktuğunu doğum yapan Meryem'e söylediğinde Meryem gülümser, bunun üzerine Yusuf gülümseyen Meryem'e gülümsememesi gerektiğini söyleyerek ebelerin içeriye girip onu tedavi etmesi gerektiğini söyler ${ }^{10}$ (Pesudo-Matta, 13).

Pesudo-Matta'da doğum sonrasında Meryem'de kanama ve ağrı olmadığ belirtilerek Meryem'in bakire olduğu vurgulanmıştır. Iokabos'un Protoevangelionu'nda anlatılan Salome'nin Meryem'e uyguladığı bekaret kontrolü ve elinin kuruması Pseudo Matta'da aynı şekilde anlatılmaktadır (Pesudo-Matta, 13; Iokabos'un Protoevangelionu, 13: 25). Pseudo-Matta'da, İsa'nın doğduğu mağara ve üzerinde parlayan yıldız hakkında ayrıntılı bilgilere yer verilmiştir. Doğum esnasında Melekler gece yarısı çevredeki çobanlara, İsa'nın doğumunu çeşitli ilahiler ve güzel sözler eşliğinde duyurmuşlar. Mesih İsa'nın kurtarıcı olarak dünyaya geldiği gece yarısında mağaranın üzerinde beliren yıldızın sabaha kadar parladığı anlatılır (Pesudo-Matta, 13).

\footnotetext{
${ }^{10}$ Ebeler için bakınız; (Wilhelm-Red, 1994: 96-101).
} 


\section{Sacit Pekak-Durmuş Gür}

Pseudo-Matta'da mağaradaki doğumun ardından Meryem'in doğumun üçüncü gününde mağaradan çıkarak evine gitmek için harekete geçtiği, İsa'yı ahıra yerleştirdiği anlatılır. Ahırda İsa'nın başında öküz ve eşeğin O'nu nefesleriyle 1sıttığı anlatılır (Pesudo-Matta, 14).

Öküz ve eşek tasvirleri erken tarihli tasvirlerden itibaren yaygın şekilde kulanılan sembolik unsurlardandır. Eski Ahit Peygamberleri'nden Isaiah ve Abakuk tarafından şu sözlerle İsa'yı müjdelediği ifade edilir;

Isaiah; "öküz sahibini, eşek ise efendisinin yemliğini bilir”.

Abakuk; "İki hayvan arasında bir peygamber tezahür edecek" (PesudoMatta, 14).

Boormans, İsa bilimlerinde O'nun doğumunun, daha da önceden vurgulandığ1 yazar. İsa'nın daha önceki yaşamının dünyevi yaşamının üstüne geçtiğini düşünür. $\mathrm{Bu}$ yaşam Musa ile İbrahim'in yaşamlarından önceki var oluşunu yansıtır. Pavlus'un öğretilerinde, İsa Mesih, "Yeni Adem" olarak ifade edilir ve hatta Adem'den önce de var olduğu yazılıdır (Boormans, 2005: 49)

Doğumun altıncı gününde Bethlehem'e giden Meryem, Yusuf ve İsa ile orada yedinci günü de geçirdikten sonra sekizinci gün bebeğin adını İsa koyarak onu sünnet ettirmiştir. İsa'nın sünnetinden sonra Yusuf, tapınağa kaplumbağa ve iki genç güvercin sunmuştur (Pesudo-Matta, 15).

Apokrif Barnabas İncili'nde diğer kaynaklardan farklı olarak doğumun Betlehem'e yakın bir çoban barınağında gerçekleştiği anlatılır. Doğum sonrasında İsa'yı kollarında kundaklayarak yemliğe yatırdığı anlatılır. Doğumun gerçekleştiği esnada, çevrede sürülerini otlatan çobanların, parlayan ışıktan korktukları ve o esnada Tanrı'nın meleğinin çobanlara görünerek doğumu müjdelediği anlatılır (Barnabas İncili, 3-4).

İsa'nın Çocukluk İncili, İsa'nın Doğumu ile ilgili ayrıntılı bilgilere yer verilmiştir (İsa'nın Çocukluk İncili, 1: 1-21).

"ve mağaranın yanına geldiklerinde, Meryem Yusuf'a doğum vaktinin geldiğini ve şehre kadar gidilemeyeceğini, mağaraya girmeleri için izin vermesini söyledi. Bu sırada güneş batmak üzereydi. Ama Yusuf aceleyle, bir ebe bulmak için ayrıldı. Yusuf ve yaşlı Yahudi kadın mă̆araya geldiklerinde güneş batmışt ve içeri girdiler. Ve gördüler ki mağara kandillerden, mumlardan, güneşin kendi ışı̆̆ından daha parlak bir ışıkla dolmuştu. Ve bebek kundaklanmış, annesi Meryem 'in göğsünü emiyordu”' (İsa'nın Çocukluk İncili, 1: 6-11).

İsa’nın Çocukluk İncili ile (1: 6-11) Iokabos'un Protoevangelionu'nda (12: 14) Meryem'in doğumu mağarada gerçekleştirebilmek için Yusuf'tan izin istediği yazar. İsa'nın Çocukluk İncili'nde mağaradaki doğumun güneş batmak üzereyken gerçekleştiği belirtilir. 4.-6. yüzyıl sarkofag tasvirlerinde Yusuf'un elindeki meşale, mağaranın karanlık ortamı ile ilişkilendirilir. Arles Museum'da 4. yüzyıla tarihlendirilen

\section{Sanat Tarihi Dergisi}


sarkofag üzerindeki İsa'nın doğumu tasvirinde, elinde meşale tutan Yusuf buna örnektir.

İsa'nın doğumu, Meryem'in Doğumu İncili'nde 8. ve 9. baplarda anlatılır (Meryem'in Doğumu İncili, 8-10). İsa'nın doğduğu yıl, ay, gün ve saatle ilgili kaynaklarda kesin bir bilgi bulunmaz. İsa'nın Çocukluk İncili ve Iokabos'un Protoevangelionu'nda doğumun, Bethlehem'e ulaşmadan önce, mağarada akşama doğru gerçekleştiği anlatılır. Matta'da Kral Hirodes Dönemi’nde (M.Ö. 4.yüzyıl) İsa'nın doğumunun gerçekleştiği ifade edilir (Matta, 2: 23). Kral Hirodes Dönem Pseudo-Matta (Pseudo-Matta, 1) ve Iokabos'un Protoevengelionu'nda kabul edilir (Iokabos'un Protoevengelionu, 22). Luka'da ise İsa'nın doğumunun M.S. 6'da gerçekleşen Quirinius Nüfus Sayımı ile aynı tarihte olduğu ifade edilir ${ }^{11}$ (Luka, 2: 4).

İsa'nın doğumu tasvirlerinde, doğumun gerçekleştiği zamana işaret eden tek ikonografik unsur Beytüllahim Yıldızı olarak kabul edilir. Matta (2: 9-11) ve Protoevangelion'da (21) Beytüllahim Yıldızı'nın doğum anında parladığı anlatılır. Brown, Çin takvimlerine göre M.Ö. 4.-5. yüzyıllar ile Johannes Kepler'in (1571-1630) hesaplamalarına göre M.Ö. 6.yüzyılda Nova, Süpernova Patlaması, Meteor Patlaması ya da Jupiter ve Saturn gezegenlerin buluşması ile açıklamaktadır (Coşkuner, 2009: 64). Olayın Beytüllahim Yıldızı olabileceğini belirten Brown, İsa'nın doğumunun M.Ö. 6.-4. yüzyıl arasında gerçekleşmiş olabileceğini belirtir (Brown, 1977: 321-323). Boormans ise İ́sa'nın M.Ö.7 ya da 6'da dünyaya geldiğini yazar (Boormans, 2005: 41). İsa'nın doğumu, Batı Avrupa'da 4. yüzyıldan itibaren yeryüzüne inen bir 1şık olarak kabul edilir ve kutlanır (Sach, Badstübner ve Neumann, 1988: 141).

Quirinius Nüfus Sayımı, Beytüllahim Yıldızı, Kral Hirodes ve Johannes Kepler'in hesaplamalarından yola çıkan araştırmacılar, İsa'nın doğumu ile ilgili çeşitli görüşlere sahiptir.

\section{Kur'an-ı Kerim'e Göre Meryem ve İsa'nın Doğumu}

İsa, Kur'an-1 Kerim'de çeşitli ayetlerde Allah'ın Elçisi, Allah'ın Sözcüsü, Allah'ın Kulu, Allah'ın Ruhu ve Mesih gibi çeşitli adlarla anılmaktadır. Ayrıca İsa'nın yanında Meryem ile ilgili birçok bilgi yer alır. İsa'nın annesi Meryem'in adı on iki surede 34 defa geçmektedir (And, 1998: 177).

"Bir de, melekler şöyle demişti: "Ey Meryem! Allah seni, kendisinden bir kelimeyle muştuluyor. Adl, Meryem'in oğlu İsa Mesih'tir. Dünya ve ahirette yüz akıdır. Allah'a yaklaştırllanlardandır” (Ali İmran Suresi: 45). Meryem'in oğlu İsa Mesih, Allah'ın resulü ve kelimesidir. Onu, kendisinden bir ruhla beraber Meryem'e atmıştır (Nisa Suresi: 171). Meryem'in oğlu Mesih, bir resulden başkası değildir. Ondan önce de

\footnotetext{
${ }^{11}$ Kral Hirodes Dönemi, İsa'nın doğduğu dönem, İsa'nın çocukluk yılları ile İsa'nın vaftiz olduğu dönemde bölge tarihi ve coğrafyası için bakınız; (Anonim, 2002: Chapter 17-18).
} 


\section{Sacit Pekak-Durmuş Gür}

resuller gelip geçmiştir. Onun annesi de özü ve sözü doğru biriydi. İkisi de yemek yerlerdi" (Maide Suresi: 75).

Meryem'in babasının adı İmran annesinin adı Hanna'dır. Hanna'nın çok yaşlı bir kadın olduğu ve herhangi bir çocuğunun olmadığı bilinir. Allah'a yalvarır ve çocuğu olursa onu Allah'a adayacağı sözünü veren Meryem (Al-i İmran: 36) doğduğunda annesi Hanna, adını Meryem koyarak O'nu hahamlara teslim eder (Al-i İmran: 36). Meryem'i yanına almak isteyen 36 kişi oklarını suya atarlar ve Zekeriyya'nın oku dışındaki diğer okların hepsi suyun dibine batar (Al-i İmran: 44). Zekeriyya, Meryem'in bakımından sorumlu olmuştur. Meryem biraz büyüdüğünde Zekeriya ona bir mescit yaptırır (And, 1998: 178). Melekler İsa'yı Meryem'e müjdeler. Adı İsa, sıfatı Mesih olacaktır (Al-i İmran: 42-46). Cebrail bir gün Meryem'e genç bir adam suretinde görünür. Meryem ise Cebrail'e (Gabriel) kötülük amacıyla geldiyse yanından çekilmesini söyler. Cebrail de ona günahtan arınmış bir oğul vermek üzere kendisini Tanrı'nın gönderdiği bir elçi olduğunu söyler. Meryem ise kendisine hiç bir insan dokunmadan nasıl çocuğu olacağını sorduğunda Cebrail, Allah'ın ne dilerse "Ol” der ve o da oluverir. Doğacak çocuk İsrailoğulları'na peygamber olacaktır, mucizeler yapacaktır şeklinde ifade eder (Meryem: 16-21; Ali-i İmran 47-51; (And, 1998: 178).

Cebrail, Hz. Meryem'in yanına yaklaşarak gömleğinin yakasından üfürmüş ve üfürüğü onun dölyatağına erişmiştir. Sonunda Meryem, İsa’ya gebe kalmıştır (Enbiya: 91; Tahrim: 12; Meryem: 22). Meryem'in çocuk beklediğini öğrenince ilk tepkiyi gösteren (Meryem'in amcasının oğlu marangoz) Yusuf olur ve bu durumu Meryem'e sorar. Meryem de ona Allah'ın Adem ile eşini erkeksiz ve kadınsız yarattığını söyler. Bunun üzerine Yusuf artık Meryem'e bir şey sormamaya karar verir ve mescitteki onun işlerini de üstlenir. Meryem bir gün teyzesinin (Yahya'nın annesi) evine taşınır. O da çocuk beklemektedir ve kendi karnındaki çocuğun Meryem'in karnındaki çocuğa eğildiğini söyler (And, 1998: 178). Tüm bu doğum sürecinin ardından uzak bir yere çekilir. Meryem, kuru bir hurma ağacının altına sığınır. Allah oradan içecek su akıtır, kuru ağacı silkelerse üzerine taze hurma döküleceğini, yiyip içmesini, sevinmesini bildirir (Meryem: 22-26).

Kur'an-1 Kerim'e göre Meryem, doğum sonrasında İsa'yı alarak kavmine gösterir. Kavmi, Meryem'in temiz bir ailenin şerefine yakışmayacak bir işe kalkıştığını düşünerek Meryem'i kınar. Meryem bütün bu söylenenler karşısında hiçbir şey söylemez ve İsa'yı gösterir. Kavimdekiler bebeğin konuşamayacağını söylerken İsa konuşur ve kendisinin Allah'ın kulu olduğunu, kendisine kitap verip kendisini peygamber yaptığını söyler (Meryem, 27-33). Meryem'in kavmi ile konuştuktan sonra İsa, kendi yaşıtlarındaki çocuklar ile aynı yaşıta gelinceye kadar bir daha konuşmadığı anlatılır. İsrailoğulları Meryem'in zina ettiği düşüncesiyle ellerine taş aldıkları, İsa'nın da konuşması üzerine Meryem'i serbest bıraktıkları yazar (Nisa, 156; Enbiya, 91; Tahrim, 12; Meryem, 27:2).

\section{Sanat Tarihi Dergisi}




\section{İSA'NIN DOĞUMU VE MERYEM'İN KUTSALLIĞINA BENZER TARIHSEL ÖRNEKLER}

Bizans sanatında İsa'nın doğumu tasvirlerinde birçok ikonografik unsur görülür. Kanonik ve apokrif kaynakların dışında Antik Dönem etkilerinin de İsa'nın doğumu konulu tasvirlerde yer aldığı görülür. İsa'nın ilk banyosu (doğum sonrasında ebeler tarafından yıkanması) yazılı hiçbir kaynaklarda yer almaz. Budda, Dionysos, Akhilleus ve İskender'in doğumu Antik Dönem konularının doğum sonrası banyo işlemlerinin tasvir edilişi ile İsa'nın ilk banyosu arasında sıkı bir bağ görülür. Araştırmacılar İsa'nın çeşitli özellikleri açısından Asur (Adad), Yunanistan (Adonis, Apollon ve Zeus), Hindistan (Agni), Thebes (Alcides / Hercules), Frigya (Attis), Finike (Baal), Afganistan (Bali), Hindistan, Çin ve Japonya (Buda / Beddhu), Siam Deva Tat (Buda), Druidler (Hesus), Misır (Horus, Osiris ve Serapis), Tibet / Hindistan (Indra), Nepal (Jao / Iao), Hindistan (Krishna), Shintos (Mikado), Pers (Mithra), İskandinav (Odin), Kafkasya/Yunanistan (Prometheus), Meksika (Quetzalcoatl), Burma (Salivahana), Suriye (Tammuz), Galyalılar (Thor), Sibyls (Evrensel Monarch), Bilingonese (Wittoba), Trakya (Zamolxis/Zamolxis), Pers (Zerdüşt/Zerdüşt) gibi çeşitli bölgelerdeki inanış biçimleri ile eşdeğer özelliklere sahip olduğunu ifade etmektedir ${ }^{12}$ (Acharya ve Murdock, 2011: 8-9).

Adem ve Havva'nın tanrı tarafından yaradılışları (yoktan var edilmeleri) ile İsa'nın Tanrı tarafından oluşturulması açısından benzer kabul edilir. Eski Ahit'te Adem ve Havva'nın yaradılışları şöyle anlatılır;

“Rab Tanrı Adem'i topraktan Yarattı ve burnuna yaşam soluğunu üfledi. Böylece Adem yaşayan varlk oldu (Yaradılış 2: 7).
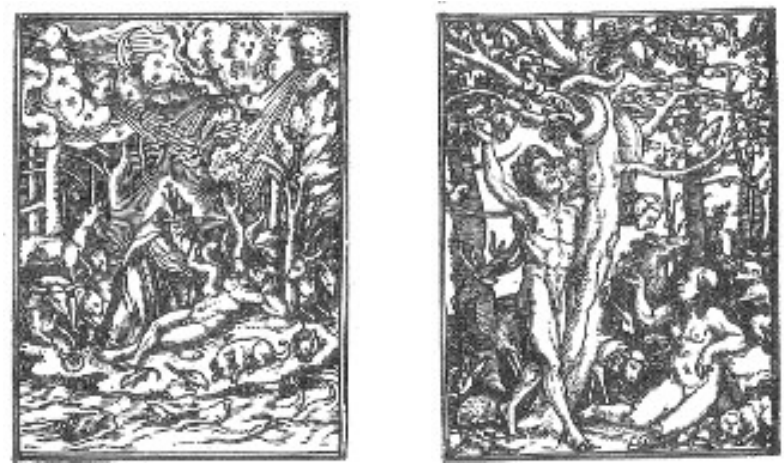

Resim 7. Adem'in Kaburga Kemiğinden Havva'nın Yaradılışı ve Yasak Meyve'yi Yemeleri (Sach, Badstübner ve Neumann, 1988: 19,55)

\footnotetext{
${ }^{12}$ Isis, Osiris ve Dionysos, İskender için bakınız; (Wilhelm-Red, 1994: 88,95).
} 
"Adem'den aldı̆̆ kaburga kemiğinden bir kadın yaratarak onu Adem'e getirdi (Yaradılış 2: 22). Adem, "İ̧̧̧e, bu benim kemiklerimden alınmış kemik, Etimden alınmış ettir” dedi, "Ona Kadın denilecek, Çünkü o adamdan alındl.” İbranice kadın (İş̧a) sözcüğü adam (Iş̧) sözcüğünden türemiştir" (Yaradılış, 2: 23) (Resim 7).

Adem ve Havva'nın yaradılışları dışında Dionysos'un doğumu ve ilk banyo tasvirlerinin İsa'nın doğumu ile benzer olduğu görülür. Yeni doğan bebeğin, kadınlar tarafından yıkanması Hıristiyanlık öncesinde görülen eserlerdeki doğum sahnelerinin kalıplaşmış bir parçasıdır. Bizans Sanatı'nda İsa'nın doğumunda, Antik Dönem eserlerinde oluşan kalıplaşmış şema tercih edilmiş gibi görülür. İsa'nın ilk banyosu, kompozisyonun genel düzenlemesi ve Meryem'in kompozisyondaki konumu, Dionysos'un doğumu sahnesinin işlendiği Roma Dönemi eserlerinden esinlenildiği görülür (Weitzmann, 1951: 37).

Dionysos'un doğumu İsa'nın doğumu ile çeşitli ölçülerde benzerdir. Antik dönem etkili birçok örnekte olduğu gibi Paris Louvre Museum'da bulunan örnek bunun göstergesidir. Misır Antinoe dokumasındaki Dionysos'un Doğumu (M.Ö. 4.-5. yüzyıllar) tasviri, İsa'nın ilk banyosundaki figürlerin duruşu, banyonun konumu, ebelerin isimleri gibi birçok açıdan benzer (Kitzinger, 1963: 100). Örnekleri çoğaltılabilen kompozisyon, Antik Dönem, Hellenistik ve Roma Dönemi etkilerinin İsa'nın doğumu ve ilk banyosu konulu kompozisyona etkisini gösterir. Özellikle ebelerden birinin oturup bebek Dionysos'u tutması, diğerinin banyoya su başalttığ1 sarkofag (2.yüzyıl) ve Roma Domus Aurea'nın duvar resimlerindeki Semele'nin konumu İsa'nın ilk banyosuna örnek gösterilebilir (Weitzmann, 1951: P1.23, 47-48). Dionysos, tıpkı isa gibi Tanrı'nın (Zeus) oğludur (Akalın, 2014: 130) (Resim 8).

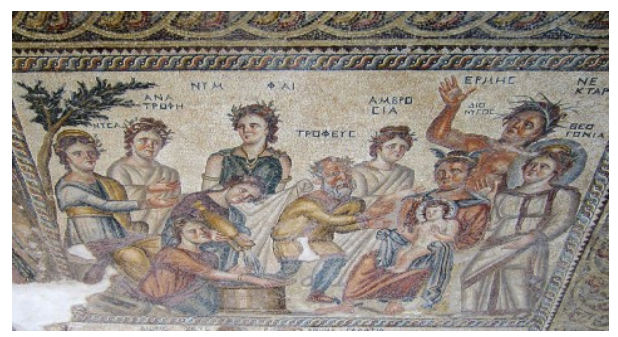

Resim 8. Dionysos'un Doğumu, Kıbrıs, Aion Evi, 4. Yüzyıl (Olszewski,2013: LXXIV Fig. 1, LXXVIII Fig. 7)

Yeni doğan bebeğin ebeler tarafından yıkanması Hıristiyanlık öncesi eserlerdeki doğum sahnelerinin kalıplaşmış bir uygulamasıdır. İsa'nın ilk banyosu, kompozisyonun genel düzenlemesi ve Meryem'in eliyle uzanabileceği bir mesafede bulunması, Dionysos'un doğumu kompozisyonlarından etkilendiğini gösterir 
(Weitzmann, 1951: 37). Dionysos'un doğumu konulu Kıbrıs, Aion Evi'nin salon mozaiği 4. yüzyıla tarihlendirilmektedir. Birbirinden bağımsız sekiz panelin sağ üst köşesinde Dionysos'un doğumu yer alır. Dionysos ve Semele'nin konumları İsa ile Meryem'in konumlarını hatırlatır. Ayrıca figürlerin duruş ve kompozisyonları, İsa'nın doğumu kompozisyonları benzemektedir. Ayrıca ebelerden birinin elindeki kaptan banyoya su boşaltması, diğerinin ise suyu ayarlaması gibi ayrıntılar İsa'nın ilk banyosu üzerinde büyük etkiye sahiptir (Olszewski, 2013: LXXVIII, Fig. 7). Ebelerden birinin oturup yıkamak üzere bebek Dionysos'u ellerinde tutması diğerinin ise banyo havuzuna su döktüğü diğer bir örnek ise 2.yüzyıla tarihlendirilen sarkofag ve Semele'nin yatağında uzandığı Roma Domus Aurea'nın duvar resimleri, İsa'nın ilk banyo uygulamasına model olduğu düşünülür (Weitzmann, 1951: 207-239, P1.23, 47-48).

Sidharta Guatama'nın doğumunun İsa'nın doğumu ile benzer olduğu görülür. Buda'nın doğum tarihi tartışmalıdır ve olasılıkla M.Ö. 563'te doğduğu ve seksen yaşında M.Ö. 483 yılında öldüğü düşünülür ${ }^{13}$ (Coomarasamy, 1916: 9). Guatama Buda'nın kişisel öyküsüyse bundan çağlarca önce yaşamış olan Sumedha'nın Buda olmaya karar vermesiyle başlar. Sumedha daha sonraki dünyaya gelişlerinde Budalığın gerektirdiği olgunluğa yetkinliğe giderek daha yaklaşmış, en son prens Vessantra adında bir ermiş kişi olarak yaşamını tamamladıktan sonra Buda olma zamanı geldiğini düşünerek Şakya Kralı Suddhodana'nın karısı Mahamaya'nın dölyatağına yerleşmiştir. Mahamaya'nın çocuğa gebe kalışı kocasıyla olan bir cinsel ilişki sonucu olmamıştır. Buda, anne karnına girmek için bir beyaz fil biçimine sahip olmuştur (Ruben, 2000: 7, 44). Krişna ve Rama destanlarını hatırlatan bir destan motifiyle karşılaşmış oluyoruz. Krişna ve Rama'nın doğumu cinsel bir ilişki sonucu olmamıştır. Adem ve Havva'nın yaradılışında olduğu gibi Meryem'in İsa'ya hamile kalmasında herhangi bir ilişki ihtiyaç duyulmaması Krişna ve Rama ile benzemektedir (Ruben, 2000: 44-59, 82).

Buda'nın annesi Mahamaya, Buda'nın doğumunun müjdelendiği bir rüya görmüştür. Gördüğü düşü şöyle ifade etmek gerekirse;

"Buda'nın annesi sarayında uyurken bir rüya görmüş. Rüyasında
çevresine nurlar saçarak gökten bir beyaz fil yanına inmiş ve sağ
bögründen karnının içine girmiş" (Ruben, 2000: 82).

${ }^{13}$ Kennett, Coomarasamy'nin aksine Buda'nın doğum yılı olarak M.Ö. 623'ü kabul etmektedir (Kennett, 1972: 3). Sıdharta Guatama'nın Buda adlı lakabı aslında aydınlanmış, uyanmış en yüce bilgeliğe ulaşmış kişi anlamlarına gelmektedir (Coomarasamy, 1916: 9). Buda'nın asıl adı Sidhatta Gotama ya da Sidharta Gautama'dır. Sidharta adı aslen amacına ulaşmış anlamlarında kullanılır. Bu ifadelere bakılarak Sidartha'nın lakap ya da unvan olduğu düşünülür. Bazı araştırmacıların savına göre Gotama adıysa Buda'nın soyadı olduğu düşünülmektedir (Coomarasamy,1916:9). Buda, Oudh yakınlarında Nepal'deki Kapilavastu yakınında Lumbini'de doğduğu ifade edilir. Buda'nın Şakya Kralı Suddhodana'nın oğlu olduğu düşünülür (Oldenberg, 2006: 16). Şakya Krallığı'nın güneybatısında daha büyük ve daha güçlü bir ülke olan Koşala Krallığı bulunmaktadır (Oldenberg, 2006: 16-17). Şakyalar'ın kökenleri tartışmalıdır. Şakyalar'ın, Pencap Bölgesi'nde, Arya kültürünün etkisi altında kaldıktan sonra Doğu'ya göçen Hindistan'ın yerli halklarından biri olduğu sanılmaktadır (Ongun, 1941: 5; Ruben, 2000: 7, 126). 


\section{Sacit Pekak-Durmuş Gür}

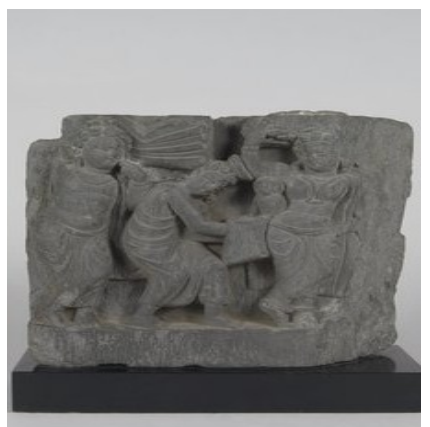

Mahamaya uyandığında rüyasını Suddhodana'ya anlatmıştır. Suddhodana eşinin rüyasını Brahmanlar'a danışarak onlardan edindiği bilgiler şöyle anlatılır; "Mahamaya'nın bir erkek çocuk doğuracă̆l ve bu çocuğun bütün dünyaya egemen bir kral olacă̆ ya da dinsel yaşamı seçerse dünyayı bilgisizlikten, yanılgıdan, cahillikten kurtaracak bir Buda olacak" (Ruben, 2000: 83) (Resim 9).

Resim 9. Buda'nın Doğumu, 3.-4. Yüzyıl, Brooklyn Museum $^{14}$

Mahamaya gördüğü rüyadan on ay sonra babasının ülkesi Devadahaya giderken Lumbini civarında ağaçlardan birinin dalına uzanırken hiç doğum ağrısı çekmeden ayakta Buda'yı doğurur (Ruben, 2000: 83). Doğum esnasında körlerin gözleri açılmış, dilsizlerin dilleri çözülmüş, topallar yürümeye başlamış, bütün ağaçlar çiçek açmış, çocuğu tanrılar yıkamış (Coomarasamy, 1916: 28).

“Maya'nın (Buda'nın annesinin) ebeliğini yapmak için gökteki Tanrılar yeryüzüne inmişler. Tanrllar Buda'yl doğurtmuşlar ve yine Tanrlar Buda'yı yıkamışlar. Buda doğar doğmaz yürümeye başlamış ve dört bir yöne yedişer adım atmış. Dört bir yöne, kendisinin insanlarl act ve ıstıraptan kurtarmak için geldiğini müjdelemiş" (Ruben, 2000: 83-84).

Doğumundan yedi gün sonra annesi Mahamaya'nın ölmesiyle babası Suddhodana, Mahamaya'nın kardeşi Mahapacapati'yle evlenerek çocuğu büyütmüştür (Coomarasamy, 1916: 28). İsa'nın doğumu Buda'nın doğumuna benzer bazı niteliklere sahiptir. Buda'nın doğumunun benzerlerine birçok Brahman Destanı'nda rastlamak mümkündür. Mahamaya'nın hamile kalarak doğum yapması Tanrılar'ın yeryüzünde doğuşu olarak kabul edilir. Krişna, Tanrı Vişnu'nun bir kılından, Rama'nın annesi ise Tanrı Vişnu'nun verdiği içkiden gebe kalmıştır. Bu destanlardaki gebe kalma şekilleri mitolojilerde sıkça görülen bir uygulamadır (Ruben, 2000: 82-83).

Hint mitolojisinde Tanrılar'ın doğuşu Buda'nın doğuşunda olduğu yaygın ve köklü bir uygulamadır. Şaman kültüründe yeni doğan bir çocuğun ruhu cennette bulunan bir ağaçtan gelerek çocuğun bedenine girer. Tek tanrılı dinlerde, insanın yaratılmasına kaynak olan Cennet Ağacı ve Şaman kültüründeki Cennet Ağacı ile Buda'nın altında doğduğu ağaç arasında benzerlik görülür. Havva'nın, Adem'in kaburga kemiğinden yaratılması da böyle bir cennet ağacı altında olmuştur (Ruben, 2000: 83-84). Kısaca, uzun yıllar çeşitli medeniyetlerin Tanrı ve Tanrıçalar'Inın doğum şekilleri İsa'nın doğumuna etki etmiştir.

\footnotetext{
${ }^{14}$ https://www.brooklynmuseum.org/opencollection/objects/93120/Fragment_of_a_Relief_Depicti ng_the_Birth_of_the_Buddha 26.11.2015-23:53 24.11.2015-04:14)
} 


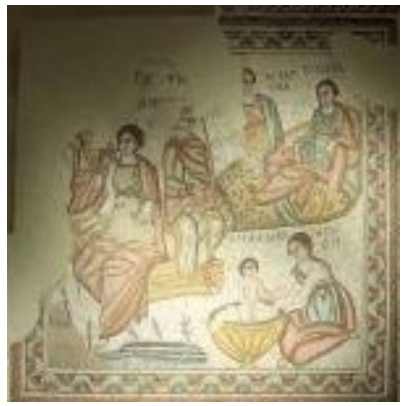

Resim 10. İskender'in

Doğumu, Lübnan,

Beyrut National Museum,

Mozaik (Kouymjian, 2012:

Fig. 62)

Yeni doğan bebeğin ebeler tarafından yıkanması

Huristiyanlık öncesi eserlerdeki doğum sahnelerinin kalıplaşmış bir uygulamasıdır (Weitzmann, 1951: 37). İskender'in doğumu tasvirleri de İsa'nın ilk banyo kompozisyonu ile benzerlik gösterir.

Lübnan, Beyrut Baalbek Müzesi'nde İskender'in Doğumu'nun betimlendiği 4.-5. yüzyıllara tarihlendirilen mozaik pano yer alır (Resim 10). Soueidié'de bir villada bulunduğu ifade edilir (Kouymjian, 2012: Fig. 62). İskender'in doğumu mozaiğinde kalabalık üslup görülür. Çoğu örnekte bir ya da iki ebe görülür. Burada kompozisyonun sağ altında bir ebenin İskender'i banyo yaptırması İsa'nın ilk banyosunu hatırlatır.

Akhilleus'un doğumu da tıpkı Dionysos ve İskender'in doğumlarında olduğu gibi İsa'nın Doğumu ile benzer üslup ve kompozisyon anlayışı içinde mozaik panolar yerini almıştır. Kıbrıs, Kato Paphos'ta Theseus Evi'nin salon mozaiğinde Akhilleus'un Doğumu betimlenmiştir (Resim 11). Günümüze sağlam ulaşan zemin mozaiğinde kalabalık bir kompozisyon görülür. Çoğu örnekte bir ya da iki ebe görülürken burada sol altta bir ebenin Akhilleus'u kucağına almış banyo yaptırırken tasvir edilmiştir. Banyo yaptıran ebenin arkasında arkasındaki diğer ebe ise banyo suyunu taşırken betimlenmiştir. Bu kompozisyon, İsa'nın ilk banyosuna üslup ve ikonografi açısından benzer niteliktedir (Bell, 1979: 237-239).

Resim 11. Theseus Evi (Salon Mozaiği) Akhilleus'un Doğumu, Kıbrıs, Kato Paphos, 5.yüzyı1 (Bell, 1979: 238)

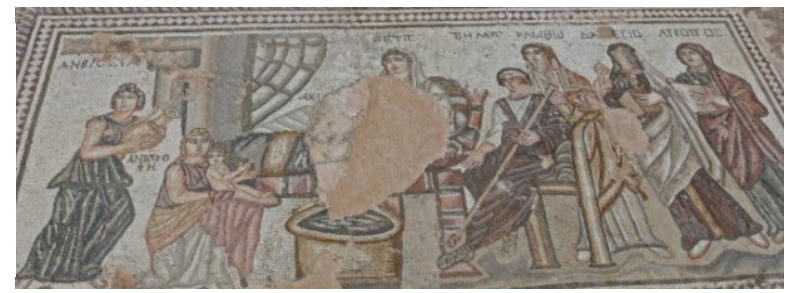

Mısır tanrısı Horus'un yaşamın ve doğumundaki bazı kesitlerin İsa'nın hayatı ve doğumu ile benzer özellikler taşıdığı görülür. Acharya ve Murdock, gerçekleştirdikleri incelemelerinde İsa'nın 25 Aralık'ta bir mağarada doğduğunu belirtmektedir. İsa'nın Tanrı-insan bir yaşam düzenine sahip olduğunu inceleyen araştırmacılar, Horus'un da tıpkı İsa gibi bakireden (İsis) doğduğu, mezara gömüldüğü ve öldürüldükten sonra tekrar dirildiğini yazar (Acharya ve Murdock, 2011: 12). Tasvirlerde bakire İsis ile oğlu Horus ve bakire Meryem ile İsa etkileşimin kanıtıdır. İkisinin de bakire olması kültürel etkileşimdir (Acharya ve Murdock, 2011: 13).

Pers-Roma tanrısı Mithra'nın bakire doğumu Hıristiyanlığı etkileyen önemli diğer doğum örneğidir. Araştırmacılar Mithra'nın bekareti üzerine çok fazla tartışmış 


\section{Sacit Pekak-Durmuş Gür}

fakat onu kutsal ve bakir bir anne olarak kabul etmiştir. Mithra'nın kayalık bir alanda bakire olarak doğum yaptığını modern Hıristiyanlık savunucularının reddetmektedir. Badiozamani, Mithra'nın tertemiz anlamına geldiğini ve Ahameniş Dönemi'nde (M.Ö. 558-330) Nahid Anahita adlı bir bakireden doğduğunu yazar (Acharya ve Murdock, 2011: 14). Her ne kadar farklı bir kültürü temsil etseler de Mithra'nın bekaret, kutsallık ve kayalık alandaki doğumu ile Meryem'in bakireliği ve İsa'nın doğumu üzerinde büyük etkiye sahip olduğu düşünülür.

Krishna'nın annesinin bakire olması ve yedi çocuk doğurması tartışılan bir konudur. Aslında bu uygulamalarla bakirelik vurgulanarak bedenin fiziki koşulları arka plana atılmış, kutsallık öne alınmıştır. Krishna'nın annesi hamile olduktan sonra bir bakire olarak Krishna'yı doğurur (Hint geleneği). Bu iki özelliği (Tanrı-İnsan), Meryem'in bekareti ve İsa'nın doğumu ile benzemektedir (Acharya ve Murdock, 2011: 17).

\section{ISA'NIN DOĞUMUNDA EPISODLAR}

Ortodoks ayinlerinde İsa'nın doğumu, halkın kurtuluşu olarak kabul edilir. Doğum gününde ekmekler pişirilir, tatlılar hazırlanır, çeşitli yemekler hazırlanır, evlerin önlerine küçük masalar konulur, buhurlar hazırlanır. Bu hazırlıkların anlamlı bir ifadesi imanın güçlendirilmesidir (Spitzing, 1989: 125). 1-6 Ocak arasında evlere gençler davet edilir ve onlara ikramlarda bulunulur. Bu uygulama Roma'da yılın ilk haftasıdır. Ev hanımları, bisküvi, fındık ve kuru meyvelerle oluşturdukları bir karışım hazırlarlar. Ayrıca soba üzerinde şarap ve yağlarla haçlar hazırlanır. İnsanlar mum 1şı̆̆ı ve şöminelerle kendilerini aydınlatır (Spitzing, 1989: 125). Noel kutlamalarından önce yeryüzünde herhangi bir ağacın kalmadığı, İsa'nın doğumu ile ağaçların tekrardan yükseldiği ifade edilir, bu doğrultuda noel ağaçları dikilir, süslenir ve İsa ile etrafın aydınlandığına inanılır. Böylece dünyanın her yıla yeniden doğduğuna inanılır (Spitzing, 1989: 125).

İsa'nın doğumunda çoğunlukla sekiz episod görülmektedir; 1.İsa'nın Doğumu, 2.Çobanlara Müjde, 3.Müneccim Kırallar, 4.Meleğin Müneccim Kırallar'a Yol Göstermesi, 5.Müneccim Kırallar Hirodes Önünde, 6.Müneccim Kırallar'ın Hediyelerini Sunmalarl, 7.Meleğin Müneccim Kırallar'a Görünmesi, 8.Müneccim Kırallar'ın Geri Dönüş Yolculuğu.

\section{Kral Hirodes'in Düşü}

Kral Hirodes, İsa'nın doğumunu öğrendikten sonra tüm olanlar hakkında bilgi toplamak için ülkedeki bilginleri ve öğretmenleri çevresine toplayarak onlardan bilgi edinir. Bu olay Matta'da şöyle anlatılır;

"Ísa'nın Kral Hirodes devrinde Yahudiye'nin Beytlehem Kenti'nde doğmasından sonra bazı yıldızbilimciler Doğudan Yeruşalim'e gelip şöyle dediler: "Yahudiler'in Krall olarak doğan çocuk nerede? Doğuda O'nun yıldızını gördük ve O'na tapınmaya geldik." Kral Hirodes bunu duyunca kendisi de bütün Yeruşalim halkı da tedirgin oldu. Bütün başkâhinleri ve 
halkın din bilginlerini toplayarak onlara Mesih’in nerede doğacă̆ını sordu. "Yahudiye'nin Beytlehem Kenti'nde” dediler. "Çünkü peygamber aracılığıyla şöyle yazılmıştır: "Ey sen, Yahuda'daki Beytlehem, Yahuda önderleri arasında hiç de en önemsizi değilsin! Çünkü halkım İsrail’i güdecek önder Senden çıkacak.” Bunun üzerine Hirodes yıldızbilimcileri gizlice çağırıp onlardan yıldızın göründüğü anı tam olarak öğrendi. "Gidin, çocuğu dikkatle arayın, bulunca bana haber verin, ben de gelip O’na tapınayım” diyerek onları Beytlehem'e gönderdi.” (Matta, 2: 3-9; Pesudo-Matta, 16).

\section{Çobanların Tapınması}

Kanonik ve apokrif kaynaklarda anlatılan İsa'nın doğumundaki ortak episodlardan biri olarak çobanların tapınması gösterilmektedir. Doğum sırasında Luka ve Matta'da sürüleriyle birlikte geceyi kırda geçiren çobanlara Tanrı'nın meleğinin görünerek İsa'nın doğumu müjdelenmiştir. Doğum esnasında etrafı büyük bir 1şık kaplar ve görkemiyle çevreyi aydınlatır. Bu ışık çevredeki çobanları korkutur ve bunun üzerine çobanlara görünen Melek, onlara mutlu bir haber getirdiğini ve İsa'nın doğumunu müjdeler. Bu olay Luka'da şöyle anlatılır;

"Korkmayın çünkü işte ben size bütün kavme olacak büyük sevinci müjdeliyorum, çünkü bugün kavme Davud'un şehrinde size kurtarlcı doğdu, O da Rab, Mesih'tir. Yemlikte yatan, kundă̆a sarllmış bir bebek bulacaksınız; size alamet bu olsun" (Luka, 2: 8-17).

Meleğin duyurusu üzerine çobanlar, Tanrı'nın müjdelediği yeni doğan bebeği görmek için ahıra yönelmiştir. Ahıra gelen çobanlar burada, Meryem ve Yusuf'la birlikte yeni doğan bebek İsa'yı kundakta görür (Luka, 2: 8-17). Apokrif kaynaklarda çobanların bu olayı görmek için ahır yerine çobanların barınağı ile mağaraya yöneldikleri anlatılır. Iokabos'un Protoevangelionu'nda (12: 14), ve İsa'nın Çocukluk İncili'nde bir mağarada gerçekleşirken (1: 1-21) Barnabas İncili'nde çoban barınağında gerçekleştiği yazar (3-4). İsa'nın Çocukluk İncili'nde, gökyüzünde korkutucu derecede beliren 1şık şöyle anlatılmaktadır;

"Ve gördüler ki mă̆ara kandillerden, mumlardan, güneşin kendi ışı̆̆ından daha parlak bir ışıkla dolmuştu. Ve bebek kundaklanmış, annesi Azize Meryem 'in göğsünü emiyordu” (İsa'nın Çocukluk İncili, 1: 6-11).

İsa'nın doğumu tasvirlerinde çobanların tapınması episodu görülmektedir. Genellikle sahnenin sol ya da sağ alt bölümünde bir ya da birkaç çoban dağlık bir alanda resmedilmiştir.

\section{Müneccim Krallar'ın Tapınması}

Müneccim Krallar'ın tapınması, Apokrif ve kanonik kaynaklarda anlatılmaktadır. Matta'da bu olay Kral Hirodes zamanında İsa'nın Beytüllahim yakınlarında doğduğunda Yeruşalim'e gök bilimcilerin geldiği anlatılmaktadır. Kral 


\section{Sacit Pekak-Durmuş Gür}

Hirodes'e Matta'da yer verilirken Luka, Yuhanna ve Markos'ta değinilmemiştir. Luka'da bu olaya yer verilmemektedir. Kral Hirodes'in Müneccim Kralları göksel olay sonucunda yeni doğan bebek İsa'yı bulmaları için görevlendirilmiştir. Bunun üzerine yola çıkan müneccimler yola çıkar ve ellerinde çeşitli hediyelerle İsa'nın huzuruna gelerek ona secde ederler. Müneccim kralların isimleri resmedildikleri alanlara göre hemen üstlerinde yazar (adlarının yazılmadığı örnekler de mevcuttur). Müneccimlerin kıyafetleri ve yanlarında getirdikleri sunular uzun yıllar araştırma konusudur. Müneccim Krallar, İsa'nın huzuruna geldiklerinde O'na altın, buhur ve mür sunmuştur. Bu hediyeler apokrif ve kanonik kaynaklarda çeşitli şekillerde anlatılır.

"Yıldızbilimciler, kralı dinledikten sonra yola çıktılar. Doğuda görmüş olduklarl yıldız onlara yol gösteriyordu, çocuğun bulunduğu yerin üzerine varınca durdu (Matta 2: 9; Pesudo-Matta, 16). Yıldızı gördüklerinde olağanüstü bir sevinç duydular (Matta 2: 10). Eve girip çocuğu annesi Meryem 'le birlikte görünce yere kapanarak O'na tapındılar. Hazinelerini açıp O'na armağan olarak altın, günnük ve mür sundular” (Matta 2: 11).

Bu olay Iokabos'un Protoevangelionu'nda şöyle anlatılır;

"Yıldızbilimciler dışarı çıktılar. Şarkta gördükleri yıldızı, mağaraya gelene kadar takip ettiler, ve yıldız mağaranın üzerinde durdu. Ve yıldızbilimciler çocuğu annesiyle birlikte gördüler; çantalarından altın, tütsü ve mür çıkardılar" (Iokabos'un Protoevangelionu, 21).

Iokabos'un Protoevangelionu'nda Müneccim Krallar'ın yanlarında getirdikleri hediyeleri çantalarından çıkarttıkları yazar. Matta'da altın, günnük ve mür olarak adlandırılan hediyeler Iokabos'un Protoevangelionu'nda altın, tütsü ve mür olarak geçmektedir. Bu gibi farklılıkların çeviri kaynaklı olduğunu düşünülür. Çünkü günnük, tütsü ve baharat gibi ortak kavramlar aslında tek bir anlam ifade etmektedir ve üçü de hoş koku sağlayan çeşitli baharat ürünleridir. Araştırmacılar bu hediyelerin doğan bir çocuğa hediye olarak sunulmasından daha çok ölen birine götürülmesini daha uygun bulmaktadırlar. Raquel, altın mür ve günnük gibi hediyelerin daha çok mumyalamada kullanıldığ belirtir (Raquel, 2013: 121).

İsa'ya çeşitli hediyeler sunan Müneccim Krallar işleri bittiğinde bütün bu olanları Kral Hirodes'e bildirmek için dönüş yolculuğuna başlarlar. Geri dönecekleri zaman dinlenmek amacıyla uykuya dalan Müneccimler'e rüyalarında bir melek görünür ve onların güzergahlarını değiştirmeleri gerektiği söylenir. Bunun üzerine Müneccim Krallar da farklı bir güzergahtan yolculuklarına devam ederler. Bu olan Matta'da şöyle anlatılır;

"Sonra gördükleri bir düşte Hirodes'in yanına dönmemeleri için uyarllınca ülkelerine başka yoldan döndüler" (Matta 2: 12; PesudoMatta, 16).

Tasvirlerdeki Müneccim Krallar'ın tapınması episodu, Matta ve Iokabos'un Protoevangelionu'na dayandırılmaktadır. İsa'nın doğumu konulu tasvirlerde bu episod Müneccim Krallara kutsal yıldızın görünmesi, Müneccimler'in Kral Hirodes huzuruna 
çıkmaları, Kral Hirodes huzurundan çıkan Müneccim Krallar'ın İsa'yı Bulmak için yola koyulmaları, Meleğin ya da yıldızın Müneccim Krallar'a yol göstermesi, Müneccim Krallar'ın İsa'ye hediyeler sunmaları, Müneccim Krallar'ın dönüş yolculukları, Meleğin Müneccim Krallar'a rüyalarında görünmesi, Müneccim Krallar'ın ülkelerine farklı yoldan dönmeleri olarak özetlenebilir. Müneccim Krallar'ın İsa'ya tapınmaları Matta'da şöyle anlatılmaktadır;

"ve işte, şarkta gördükleri yıldız önlerinde gidiyordu; ta çocuğun bulunduğu yere kadar gelerek üzerinde durdu. Onlarda yıldızı gördükleri zaman, taşkın sevinçle sevindiler. Eve girip anası Meryem ile çocuğu gördüler; ve yere kapanıp ona secde klldılar; hazinelerini açarak ona hediyeler, altın, günnük ve mür takdim ettiler" (Matta, 2: 9-13).

Yıldızı takip ederek İsa'yı bulan Müneccim Krallar'ın İsa'ya secdeleri Barnabas İncili'nde şöyle anlatılır;

"çocuğu ve annesini buldular, eğilerek ona secde ettiler. Ve baharat gümüs ve altın hediye ettiler" (Barnabas İncili, 6-7) (Resim 12).

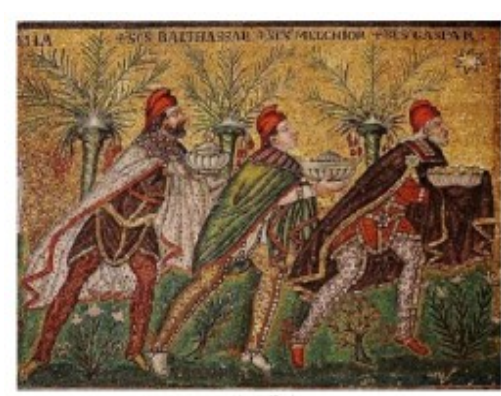

Resim 12. Ravenna, San Apollinare in Nuovo, Müneccim Krallar'ın İsa'ya Hediyeler Sunmas1 (Raquel, 2013: 121, Fig. 12)
Pesudo-Matta'da gerçekleşmesi üzerine Doğu'dan Kudüs'e Müneccim Krallar gelerek hediyeler sunduğu yazmaktadır (Pesudo-Matta, 15-16). Çeşitli kaynaklarda farklı şekillerde adlandırılan Müneccim Krallar'ın sayı ve karakteristik özellikleri hakkında herhangi bir özellik belirtilmemiştir. Kısaca altın, günnük ve mür olarak ifade edilen hediyelere bakılarak üç kişi

oldukları tahmin edilir. Tasvirlerde üç kişi olarak ifade edilen figürler bazen farklı kıyafetlerle birbirinden ayrılmaktadır. Jerphanion, kilise duvar resimleri ve küçük el sanatları dahil olmak üzere tüm tasvirlerde görülen üç Müneccim Kralı, sayı ve hediye açısından değerlendirmek yerine insan yaşamının üç evresini sembolize ettiğini düşünmek daha doğrudur (Jerphanion, 1925: 78). MacDonald, Müneccim Krallar'ın İsa'ya sundukları altının tanrısallığ ve yüceliğini; tütsünün günahsız ve mükemmel yaşamı; mürün ise İsa'nın çektiği acıları ve ölümünü sembolize ettiğini belirtir (MacDonald, 2000: 32).

Kaynaklarda, Müneccim Krallar'ın yolculukları “Doğu'dan Geldiler” şeklindedir. Epiphanios, Müneccim Krallar'ın Arabistan'dan geldiklerini; Tarsus'lu Diodoros ve İskenderiye'li Kyrillos ise Persli olduklarını yazar. Ankyra'lı Theodoros ise Müneccim Krallar'ın Khalkedealı olduklarını belirtir (Carr ve Kazdhan, 1991: 22). Tasvirlerde Müneccim Krallar çoğunlukla sivri başlıklı ve dar pantolon giyimlidir. 
Bütün bunlara bakılarak Müneccim Krallar'ın İskit, Pers ya da Firig halkına mensup olduğu düşünülür.

Müneccim Krallar, 3. yüzyıldan itibaren Roma katakompları ile 4. yüzyıldan itibaren Roma sarkofaglarında görülmektedir (Schiller, 1971: 100). Ravenna San Apollinare in Nouvo ve Santa Maria Maggiore'de ise erken örnekleri görülür (Schiller, 1971: 101). Kappadokia Kiliseleri’nde İsa'nın doğumu kompozisyonlarında yaygın bir şekilde tasvir edilen Müneccim Krallar, kiliselerde tahtta Meryem'in kucağındaki İsa'ya secde eden ve hediyeler sunarken betimlenmiştir. Hediyeler sunan bir diğer uygulamanın benzerine, I. Theodosius Dönemi'nde 390 yılında Misır'dan getirilerek İstanbul'daki Hipodroma yerleştirilen Dikilitaş'ın mermer kaidesinde, ellerindeki çeşitli hediyeleri sunan Pers ya da Firig asıllı figürlerin kıyafetleri, başlıkları ve kompozisyon anlayışı ile benzemektedir. Bardill, buradaki figürleri imparatorluk ailesine hediyeler sunan Barbarlar olarak tanımlamıştır (Bardill, 2010: 162) (Resim 13).

Ayvalı Kilise (913-920) (Coşkuner, 2009: 84), Eski Tokalı Kilise (10. yüzyıl sonu) (Restle, 1967: I, 23-26), Hagios Theodoros Kilise (11. yüzy1l) (Hild ve Restle, 1981: 290) ve El Nazar Kilise (10. yüzyıl)'de (Coşkuner, 2009: 144) Müneccim Krallar'ın tapınması tasvir edilmiştir (Önen-Alev, 2014: 42-45). Kaynaklarda adları geçmemesine rağmen tasvir edilen Müneccim Krallar'ın Secdesi'nde zamanla Meryem'in nişanlısı Yusuf'da görülmeye başlar. 3.-4. yüzyıldan itibaren sarkofaglarda tek bir kompozisyon ya da altlı üstlü yatay şeritler ile birbirinden ayrılmış kompozisyonlar şeklinde betimlenmiştir. 4. yüzyıl Aurelius Sarkofagı'ndaki kabartma kompozisyonda sahne yatay şekilde ikiye bölünmüştür. Üstte merkezde kundakta yatan İsa'nın başucunda Meryem, ayakucunda ise elinde meşale tutan Yusuf betimlenmiştir. Kompozisyonun altında ise Üç Müneccim Kral betimlenmiştir. Müneccimler elleriyle sol üstteki yıldızı işaret ederlerken betimlenmiştir. Burada dikkati çeken bir diğer husus ise aynı zamanda Müneccim Krallar'ın üstteki yıldız ile aynı esnada kundaktaki bebek İsa'yı da işaret ettikleridir. 3. yüzyıla tarihlendirilen Vatikan Museum'daki sarkofagta

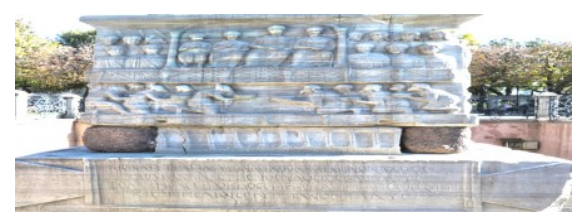

Resim 13. Dikilitaşın Mermer Kaidesi

(Bardill, 2010: 161, Fig. 9.12) da Meryem'in kucağında İsa ve O'na çeşitli hediyeler sunan Müneccim Krallar tasvir edilmiştir. Kısacası 3.-4. yüzyıldan itibaren Müneccim Krallar'ın tapınması, İsa'nın doğumunda yerini almaya başlamıştır.

Birbirlerinin kopyaları gibi tasvir edilen Müneccimlerin kıyafet farklılıklarının yanında yaş ve ten renkleri ile de birbirlerinden ayrıldığı görülür. Kappadokia Bölgesi Ihlara Vadisi'ndeki Ağaçaltı Kilise'nin güney haç kolunda yer alan Müneccim Krallar örnek gösterilebilir. Ayrıca burada olduğu gibi birçok tasvirde de figürlerin isimleri (Gaspar, Balthasar ve Melkhior) başlarının üst ya da yan bölümlerinde yazmaktadır (Thierry, 1963: 78, Fig. 18). 6. yüzyıla tarihlenen Ravenna'daki Maksimianus Katedrası'nda Müneccim

\section{Sanat Tarihi Dergisi}


Krallar'ın tasvirlerindeki yaş farklılıkları dikkat çeker. 6. yüzyıldan sonra isimleriyle anılan Müneccim Krallardan Gaspar tütsü sunan sakalsız genç; Balthasar mür sunan sakallı orta yaşlı; Melkhior altın sunan beyaz saç ve sakallı, yaşlı kral olarak tasvir edilir (Schiller, 1971: 101). Schiller'in bu tanımlarına bakılarak genç, olgun ve yaşlı olarak betimlenen Müneccim Krallar, Jerphanion'un da vurguladığı gibi insan yaşamının üç evresini sembolize ettiği düşünülür (Jerphanion, 1925: 78).

\section{İsa'nın Doğumu Tasvirlerinde Görülen Çeşitli Uygulamalar}

İsa'nın doğumu tasvirlerinde mekan ve zaman karmaşası uzun yıllar tartışılmıştır. J.R. Martin (1955), N. Thierry, (1963), M. Restle (1967), C. D. Kalokyris (1969), H. Maguire (1977: 123-174), H. L. Kessler, (1979: 449-456), S. Y. Ötüken (1984), H. Sach ve E. Badstübner ve H. Neumann (1988), G. Spitzing (1989), A. W. Carr (1991: 2174-2175), A. Karpozilos ve A. Kazhdan ve A. Cutler (1991: 290-291), R. F. Taft ve A. W. Carr (1991: 651-653), E.P.Sanders (1995), G. Jazsai (1994: 120-125), P.Wilhelm-Red (1994: 86-122), H. Maguire (1996: 1-25), M.Brog (1999: 179-186), W. Macdonald (2000), L. Arad (2003), G. Vikan (2003), I. Kalavrezou (2005: 103-117), G. Vermes (2006: 64), M.D. Roberts (2007: 102), H. Blank (2008), P. Tritsaroli, ve F. Valentin (2008: 83-113), B. Coşkuner (2009), S. Acharya ve D.M. Murdock (2011), ve A. Önen-Alev (2014) başta olmak üzere birçok araştırmacı, İsa'nın doğumuyla ilgili çeşitli görüşler sunar. Bunları alt başlıklar halinde incelemek doğru olur.

\section{Mekan}

Çocukluk döneminden itibaren yortu olarak kabul edilen İsa'nın doğumu, Kanonik (Matta, 1:18-25) ve (Luka, 2: 6-7) ile (Apokrif Barnabas İncili, 3-4), (İsa'nın Çocukluk İncili, 1: 1-21), (Pseudo-Matta,13-14) ve (Iokabos'un Protoevangelionu, 1721)'de anlatılmaktadır. Çalışmalarda İsa'nın doğduğu mekanın ahır, han, ev, çoban barınağı ya da mağara olduğu şeklinde çeşitli görüşler bulunmaktadır (Resim 14-15). Matta ve Luka'da İsa'nın Bethlehem'e nüfus sayımı için gittiklerinde handa yer olmadığı için yemlikte doğum yaptığı ifade edilir. Apokrif İnciller'de çoğunlukla mağara, Matta ve Luka'da ise ahır İsa'nın doğumunun gerçekleştiği mekan olarak ifade edilir. Çeşitli tasvirlerde ise bir han (daha çok saray odası) ya da ev olarak tasvir edilmiştir.

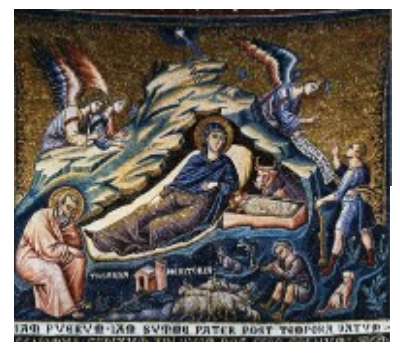

Resim 14. Trestevere, Roma Santa Maria Kilisesi, Apsis Kemeri, 1296-1300 (SalvadorGonzalez, 2012: 8)

Resim 15. Giotto, Nativity Fresko, 1305, Scrovegni Chapel, Padua (Wilhelm-Red, 1994: 97-98, Fig. 5)

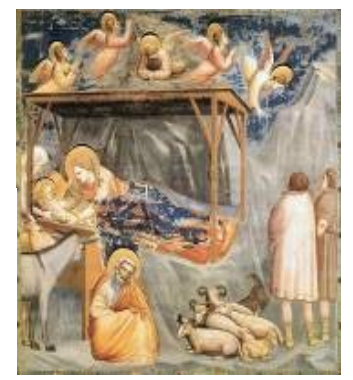


Kappadokia kiliselerinde İsa'nın doğumu apokrif kaynaklı olarak mağara içinde tasvir edilmiştir. Lafontaine-Dosogne, tasvirlerdeki mağara ve ebe figürlerinin Filistin kökenli olduğu ifade eder (Lafontaine-Dosogne, 1975: 212). Raquel, kundaktaki bebek İsa'nın sadece yüzünün açık olmasının Filistin geleneği olduğunu yazar (Raquel, 2013: 110) (Resim 16-17).

Çeşitli kiliselerde ve litürjik eserlerde doğumun gerçekleştiği mekanın yarı mağara yarı ahır benzeri bir mekanda gerçekleşmiş olabileceği gibi bir mekan anlayışı görülür.
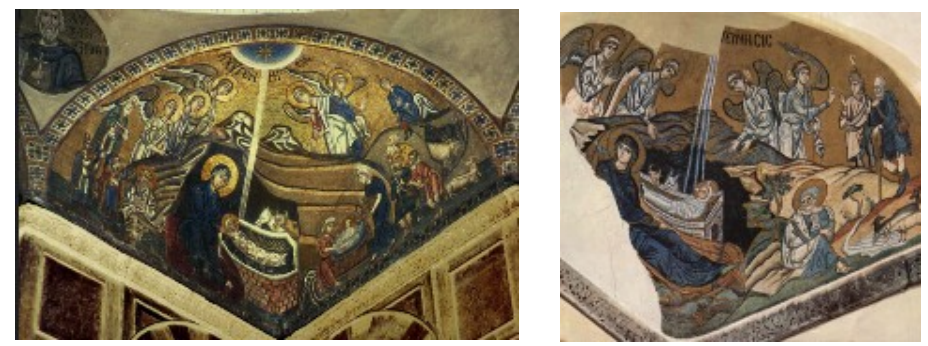

Resim 16. Yunanistan, Hosios Lukas Kilisesi 1050, İsa'nın Doğumu (Lazarides, 1987: 44,Fig.25)

Resim 17. Yunanistan, Daphni Kilisesi, Tromp, İsa'nın Doğumu (Sağ) ${ }^{15}$

\section{İSA'NIN DOĞUMUNUN BİZANS SANATINDA TASVİR EDİLIŞi}

Enkarnasyon, karanlığın derinliklerinden Tanrı'nın yeryüzüne inişi anlamına gelir ve insanlık için ilahi ışığın İsa'nın doğumuyla parladığına inanılır. Bizans sanatında resimler anlamlı imge ve sembollerle doludur. Litürji, Eski Ahit ve Yeni Ahit metinleri doğrultusunda oluşturulan ritüeller ve sembolleri içerir (Palli, 1994: 103-106). Müjde ve İsa'nın doğumu ile tasarlanan ritüeller çeşitli tasvirlerle zenginlik kazanmıştır. Ayrıca Ökaristi Ayini eşliğinde kiliselerde İsa'nın doğumu kutlanmıştır (Spitzing, 1989: 124-125). 4. yüzyıla tarihlendirilen sarkofaglarda İsa'nın doğumunun tasvir edildiği

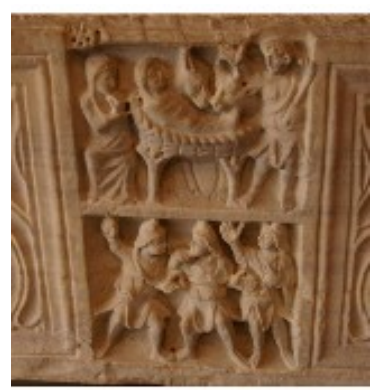
görülür (Sach, Badstübner ve Neumann, 1988: 141). Erken tarihli örneklerin sarkofaglarda işlenmesinin, ölüm öncesi yaşamların ölüm sonrasına etki edeceğine inanımaktadır (Spitzing, 1989: 126). Ayrıca erken tarihli lahitlerin sipariş üzerine oluşturulması, üzerlerindeki doğum kompozisyonları ile açıklanabilir (Sach, Badstübner ve Neumann, 1988: 141). 5. yüzy1ldan itibaren Filistin'deki ampullalarda İsa'nın doğumunun (mağara ve yemlik tasvirli örnekler) tasvir edildiği görülür (Spitzing, 1989:

Resim 18. İsa'nın doğumu ve Üç Müneccimler, 4. Yüzyıl, Sarkofag, Arles Museum

\footnotetext{
${ }^{15}$ (https://www.youtube.com/watch?v=JVP3D9Q0QF0 20.11.2015-20:48)
} 
127; Wilhelm-Red, 1994: 95). Filistin tasvirlerinde mağaralar kadar ahırlar da doğum konulu tasvirlerde görülmektedir. Mağara tasvirleri efsanevi uygulamalardır. Örneğin Girit Kaz Dağları'nda bir mağaradaki Demeter-Persephone ile Dionysos-Zeus tasvirlerini hatırlatır. Tanrılar'ın mağaralardaki doğum işlemleri Hıristiyanlık öncesinde Yunanlar'ın mitolojilerinde görülmektedir. Mağaraların karanlık ortamları Ortodoks Kilisesi'nin teolojik düşüncesini yansıtmaktadır (Spitzing, 1989: 127-128).

Kilise doktrinlerine göre temsili olarak İsa bir mağarada evrene 1şık olarak doğmuştur. Dünyanın karanlığı mağara, İsa'nın doğumu ise insanlığın karanlığını aydınlatan 1şık olarak kabul edilir (Spitzing, 1989: 128). İsa'nın doğum öncesi anne karnındaki konumu ile mağaranın karanlığı ve evrenin karanlığ 1 sembolik açılardan eşdeğer görülür (Spitzing, 1989: 128). Erken örneklerden itibaren İsa'nın kundaklanmış beşiğinin başında O'nun bedenini isıtan öküz ve eşeğin tasvirlerde görülmeye başladr (Sach, Badstübner ve Neumann, 1988: 141). 4. yüzyıl örneklerinde İsa bir sepet ya da gıda kasesi formundaki beşik/yemlik içinde, çevresinde ise öküz ve eşek yer alır (Spitzing, 1989: 127). Bu gibi tasarımlar Roma ve Galya sarkofaglarında görülmektedir (Schiller, 1971, 59). Taft ve Carr, tasvirlerde İsa, yemlik, eşek ve öküzün, 6. yüzyıldan sonra işlendiğini belirtmektedir (Taft ve Carr, 1991: 1440). Schiller, burada Taft ve Carr'ın yanıldığını belirterek 4. yüzyıla tarihlenen Milano San Ambrogio'daki lahit kapağında öküz ve eşeğin İsa'nın kundağı başında yer aldığını belirtmektedir (Schiller, 1971, 59). Sach, Badstübner ve Neumann çalışmalarında 3. yüzyılda öküz ve eşek gibi çeşitli hayvanların Yahudi ve Putperestleri temsil eden hayvanlar olduğunu belirtir ve 4. yüzyıl sonuna tarihlendirilen Milan, S. Ambrogio'da Stilicho Lahiti'ndeki tasvirlerin buna örnek olduğunu belirtir. 320-325 arasına tarihlendirilen Roma'daki lahit buna örnektir (Sach, Badstübner ve Neumann, 1988: 141). Schiller, İsa'nın doğumundaki hayvanların Antik Dönem mitolojik unsurlarla açıklanacağını belirtir (Schiller, 1971: 60). Kilise babalarından Ambrosios (339-397) ve Augustinus (354-430)'a göre öküz, seçilmiş Yahudi halkını, eşek ise kafirleri sembolize eder. Nazianzoslu Gregorios, öküzün kanunun boyunduruğu altındaki insanları; eşeğin putperesliğin günahlarıyla dolu ve Tanrı'nın oğlunu yalanlayan insanları temsil ettiğini yazar. Schiller ise öküzü günahsız insanlar, eşeği günahkarlar olarak yorumlayarak savını Eski Ahit'e dayandırır (Schiller, 1971, 60) (Resim 19).

Resim 19. İsa'nın Doğumu, Stilicone Sarkofag1, Sant Ambrogio, Milan, 4. Yüzyıl

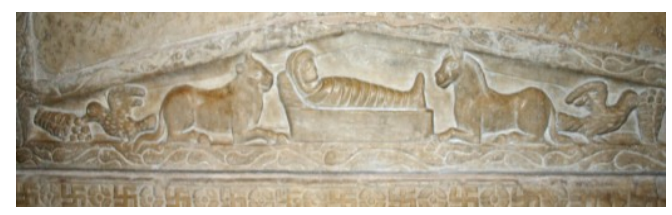

4. yüzyıla tarihlendirilen Arles Museum'daki sarkofagda, üst solda Meryem oturmakta, önünde kundakta İsa (başında hale yok), kundağın arkasında eşek ve öküz, 


\section{Sacit Pekak-Durmuş Gür}

kundağın ayakucunda ise Yusuf yer alır ${ }^{16}$ (Spitzing, 1989: 127). Yusuf, sol elinde meşale tutar sağ eliyle Meryem'in başı üzerindeki yıldızı işaret eder. Üstteki bu kompozisyonun hemen altında (üst ve alt kompozisyon yatay bir şeritle birbirinden ayrılmış) Müneccimlerin secdesi tasvir edilmiştir. Müneccimlerden sol ve sağdakiler elleriyle üstteki yıldızı işaret eder, ortadaki işe olayın şaşkınlığıyla sağ elini ağzına getirmiştir (Resim 18).

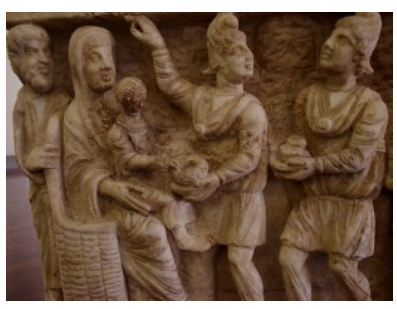

Resim 20. Müneccimlerin İsa'ya Hediyeler Sunması, Roma, Vatikan Museum, 320-350, Trinity Sarkofag1, Ayrınt1 (Anna Lumaca Arşivi, Pinterest)

Spitzing, Sach, Badstübner ve Neumann, erken tarihli İsa'nın doğumu tasvirlerinde Meryem ve Yusuf'un yer almadığını yazar. 4. yüzyıla tarihlendirilen Roma, Marcus Klaudianus'un lahitinde Meryem ve Yusuf yer alırken Stilicone ve Sant Ambrogio örneklerinde Meryem ve Yusuf tasvir edilmemişir (Sach, Badstübner ve Neumann, 1988: 141; Spitzing, 1989: 127; Spitzing, 1989: 127).

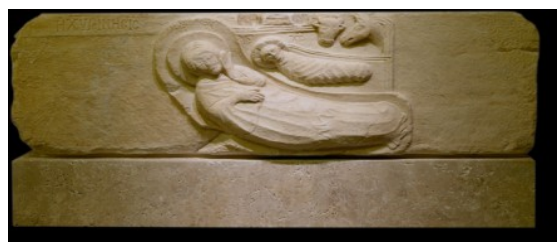

Resim 21. Mermer Rölyef, İsa'nın Doğumu, Yunanistan, Byzantine \& Christian Museum Arşivi, 4.-5. Yüzyıl

Birçok araştırmacı tarafından erken tarihli İsa'nın doğumu tasvirlerinde Meryem ve Yusuf'un yer almadı̆̆ 1 ifade edilse de 330'a tarihlendirilen Marcus Klaudianus'un lahitindeki İsa'nın doğumu tasviri bu ifadeleri reddetmektedir (Sach, Badstübner ve Neumann, 1988: 141; Spitzing, 1989: 127).

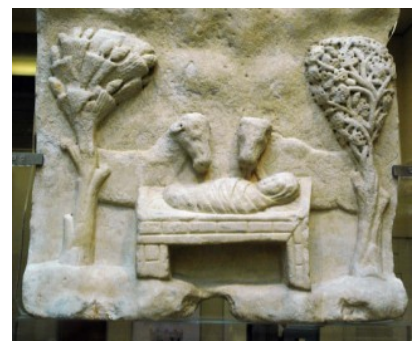

Resim 22. Mermer Rölyef, İsa'nın Doğumu, Yunanistan, Byzantine \& Christian Museum, 4.-5. Yüzyıl (Coşkuner, 2009: 72, Resim 2)

Vatikan Museum'da yer alan mermer sarkofagta tasvir edilen Müneccim Krallar'ın İsa'ya hediyeler sunması, 4. yüzyıla tarihlendirilen örneklerde de İsa'nın dışında Meryem ve Yusuf'un yer aldığını gösterir (Spitzing, 1989: 127). Sach, Badstübner ve Neumann, 431 Efes Konsili ile Meryem'in Tanrı anası olduğunun kabul edilmesiyle Meryem tasvirlerde resmedilmeye başlar. Sach, Badstübner ve Neumann da erken

16 Erken Bizans Dönemi tasvirlerinde hale kullanımında net bir uygulamanın olmadığı görülür (Carr ve Kazhdan, 1991a: 1487). Bizans sanatında hale kullanımları için bakınız; (Carr ve Kazhdan, 1991a:1487; Sunay, 2012: 197-213). 
tarihli örneklerde Meryem, Yusuf ve çobanların resmedilmediğini yazar (Sach, Badstübner ve Neumann, 1988: 141) (Resim 20-23).

Erken tarihli bazı örneklerde temsili bir çoban görülür. Yahudiliğin temsili öküz, Putperestliğin simgesi olarak da eşek tasvir edildiği düşünülür ve 5. yüzyıla tarihlendirilen sarkofag, fildişi levhalar ve ampullalarda görülür (Spitzing, 1989: 127).
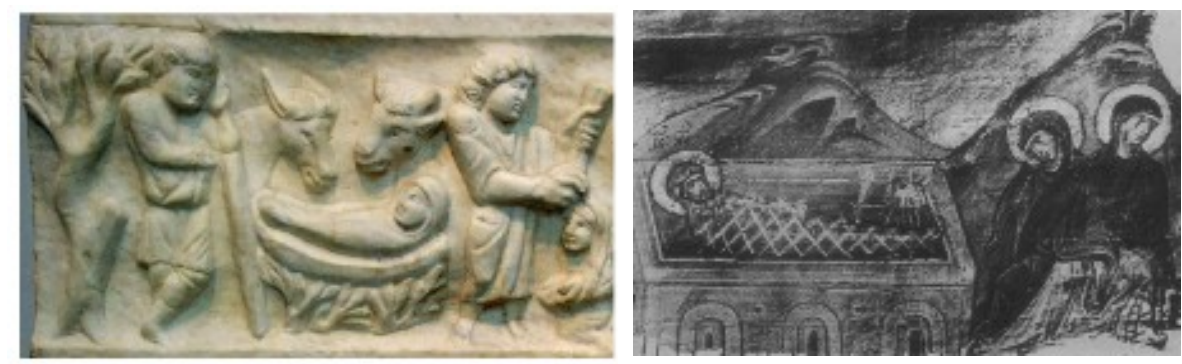

Resim 23. İsa'nın Doğumu, Marcus Klaudianus Lahiti, Roma Palazzo Museum Arşivi, 330 (Sol), Resim 24. Meryemler İsa'nın Mezarı Başında, Berlin, Staatsbibliothek, gr. qu. 66, fol. 96r (Sağ) (Maguire, 1977: Fig. 19)

Maguire, yemlik-sarkofag; kefen-kundak gibi eşleştirmelerin iki sahnenin tematik bütünlük oluşturmasıyla ilgili olduğunu açıklamaktadır (Maguire, 1977: 138). Sarkofaglardaki Müneccim Krallar tasvirlerin vazgeçilmezi olmuştur. 4. yüzyılın ortalarından itibaren tasvirlerde Müneccim Krallar ve çobanlar görülür (Spitzing, 1989: 127). Çoban ve büyücüler artık görüntüde aynı anda görünür ve temsili öküz ve eşek gibi resmedilirler. Bunlar aslında Yahudi-Hıristiyan ve Pagan-Hıristiyan uygulamasının bir parçasıdır. Tanrı'nın nurunun gök parçası gibi parlar. 5.yüzyılın ikinci yarısından itibaren göktaşı-yıldız uygulamaları tasvirlerde yerini alır. Dünyanın karanlığı (Yuhanna, 1: 1-8) olarak ifade edilen sembolik uygulama aslında İsa'nın doğduğu mağaradır olarak kabul edilir (Spitzing, 1989: 127).

Apokrif kaynaklara göre Yusuf, doğum esnasında bir mağara tespit ederek Meryem'i ve kendi çocuklarını (?) mağaraya yerleştirir. Yusuf, daha sonra çocuklarıyla birlikte Bethlehem çevresinde ebe aramaya gider (Iokabosun Protevangeliumu, 18: 1). 5. yüzyıldan itibaren, Kanonik kaynaklı tasvirlerde İsa'nın doğum yeri olarak ahır ya da han gibi işlendiği görülmektedir. 6. yüzyıldan itibaren Filistin örneklerindeki İsa'nın doğum yeri olarak mağara tasvir edilmiştir. 6. yüzyıldan itibaren Meryem, doğum sonrasında bitkin bir halde bir şilte üzerinde, İsa ise daha çok altar benzeri bir mekan üzerinde yer alır. 6. yüzyıldan itibaren kompoisyon kalabalıklaşır, Meryem ve Yusuf'un yanında ebeler, çobanlar ve Müneccim Krallar hemen tüm tasvirlerde yer alır (Sach, Badstübner ve Neumann, 1988: 142). Ötüken, İsa'nın doğumu tasvirlerinde 7. yüzyıldan itibaren İsa'nın İlk banyosunun görülmeye başladığını yazmaktadır. Diğer araştırmacılardan farklı bir tarihlendirme sunan Ötüken, 10. yüzyıldan itibaren de Müneccim Krallar'ın tasvirlerde yer aldığını belirtir (Ötüken, 1984: 131). 


\section{Sacit Pekak-Durmuş Gür}

İtalya Ravenna'daki Maksimianus'un fildişi tahtınının (545-553) arkalık bölümündeki İsa'nın doğumu tasvirinde Salome, Meryem'e doğum işlemleri sırasında yardım etmektedir (Kessler, 1979: 452, Fig. 65; Sach, Badstübner ve Neumann, 1988: 142; Wilhelm-Red, 1994: 98-99) (Resim 25). 726 öncesine tarihlendirilen eserlerde İsa'nın doğumu, İsa'nın ilk banyosu, çobanların secdesi ve Müneccim Krallar'ın secdesi gibi konular birbirinden bağımsız kompozisyonlar şeklinde tasvir edilirken 726$842 / 3$ sonrasında bütünü oluşturan episodların tek bir sahne içinde yer aldıkları görülür. 6. yüzyıldan sonra doğum ve ilk banyo birlikte tasvir edilir (Spitzing, 1987: 128).

Resim 25. İsa'nın Doğumu, Ravenna Başpiskoposu

Maksimianus'un Fildişi Taht1,550 (Kessler, 1979: 454, Fig 65)

Kompozisyonun merkezinde kundaklanmış Isa, sol

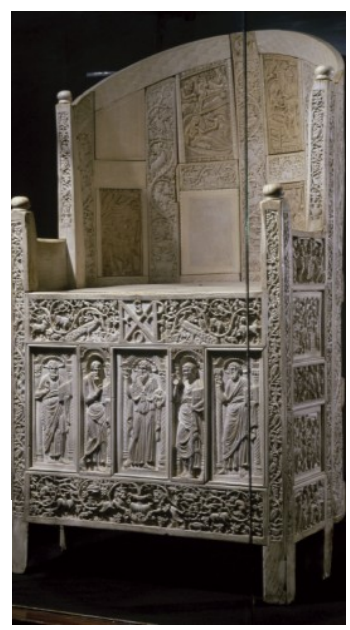

altta şilte üzerinde Meryem sol eliyle Salome'nin uzattığı bezi almaktadır. İsa'nın ayakucunda ise Yusuf ayakta ve İsa'yı sağ eliyle işaret eder. İsa'nın beşiği başında eksende yıldız, yıldızın solunda öküz sağında ise eşek görülür.

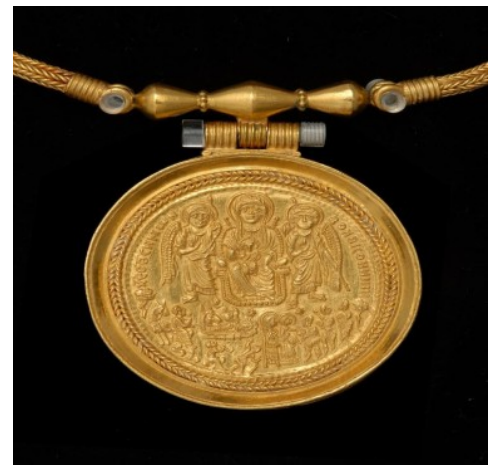

Resim 26. İsa'nın Doğumu, Altın Enkolpion, 584, Konstantinopolis, Dumbarton Oaks Museum (Brown, 1979: 313)

Dumbarton Oaks Museum'da 6. yüzyıla tarihlendirilen altın Enkolpion üzerinde, üçlü sahne düzenlemesi görülür (Brown, 1979: 3012313) (Resim 26). Kompozisyonda episodalar birbirinden herhangi bir konturla ayrılmamıştır. Üstte tahtta Meryem ve kucağında İsa, tahtın iki yanında ayakta baş melekler görülür. Sol altta kundakta İsa ve hayvanlar, olaya tanık olan çobanlar tasvir edilmiştir. İsa'nın sağında, Müneccim Krallar'ın secdesi episodu görülür. Burada, İsa üç, Meryem ve yıldızlar ise iki defa resmedilmiştir.

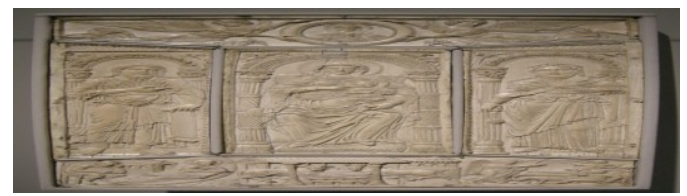

Resim 27. İsa'nın Doğumu, Lorsch İncili, Fildişi Arka Kapak, Londra Victoria and Albert Museum, 800 Civarı

Kappadokia kiliselerinde olduğu gibi birçok yerde, İsa'nın doğumu mağara içinde tasvir edilmiştir. Mağaradaki yemlik içinde kundaklanmış İsa ve üzerinde yıldız, hemen yanında Meryem ile ebeler görülmektedir. 8. yüzyıldan itibaren Salome, İsa'nın 
ilk banyosunda vazgeçilmez figürlerden sadece biridir. 9. yüzyıldan itibaren melekler korosu kompozisyonun vazgeçilmez diğer unsurlarıdır (Taft ve Carr, 1991: 1440).

Victoria and Albert Museum'da yer alan Lorsch İncili'nin fildişi örneğinde İsa'nın doğumu tasvir edilmiştir. Merkezde ahır ya da han benzeri bir mimari altında İsa, başında ise öküz ve eşek görülür. Eksenin solunda Meryem ve hemen solunda sandalye üzerinde düşünen (sol elini yüzüne yaslamış) Yusuf dikkat çeker. Merkezdeki mimarinin sağında ise bir melek çobanlara olayı müjdelemektedir. Bu durum Luka'da anlatılmaktadır (Luka, 2: 8-9). Melekler çobanlara bu olayı müjdelerken korkmamaları gerektiğini belirtmiştir (Spitzing, 1989: 129) (Resim 27).
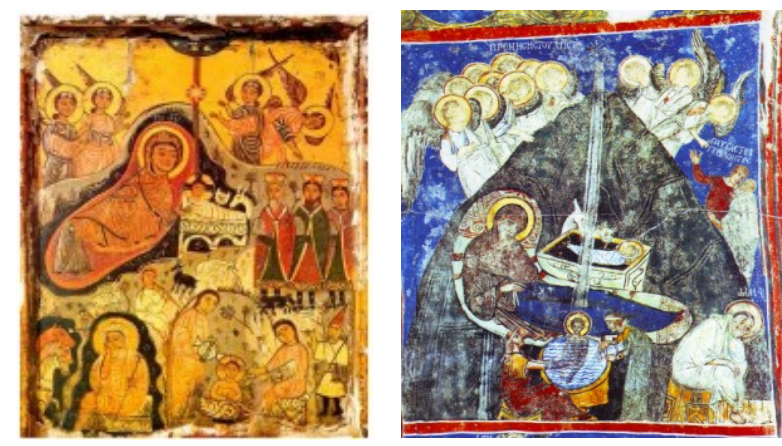

Resim 28. İsa'nın Doğumu, Kıpti ya da Ermeni İkonası, 7. Yüzyıl (sol)

Resim 29. İsa'nın Doğumu, Göreme Tokalı Kilise, 10. Yüzyıl (Pekak Arşivi, 2012) (sağ)

Yunan, Roma ve Erken Hıristiyan Dönemi eserlerinde yeni doğan bebeklerin fiziki ve dini açıdan kirli olduklarına inanılarak banyo yaptırılmaları gerektiğine inanılır (Resim 28). Sembolik bu uygulamalar deniz ve irmak sembolleri ile de temsil edilir (Spitzing, 1989: 128).

İsa'nın doğumu ve banyosunun resmedildiği sahnelerde kutsal yıldız İsa'nın üzerine inmektedir. Tanrı'nın nuru olarak kabul edilen yıldızdan doğan ışık (1şık yolu) tasvirlerde iki defa resmedilen İsa'nın (kundakta yatan İsa ve banyo yaptırılan İsa)
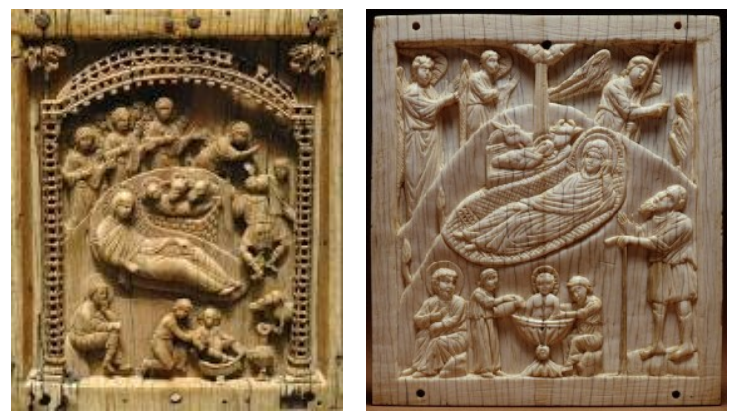
ikisinin üstünden geçer (Spitzing, 1989: 128) (Resim 29).

Resim 30. İsa'nın Doğumu, 10. Yüzyıl, Paris Louvre Museum, Fildişi Tripticon (sol)

Resim 31. İsa'nın Doğumu, 10. Yüzyıl, Baltimore Museum, Fildişi Levha (sağ)

10.-11. yüzy1la tarihlendirilen Paris Louvre ve Baltimore'da yer alan fildişi örneklerde bu uygulama açıkça görülmektedir. 10.-11. yüzyıla tarihlendirilen örneklerde 
gökyüzünden inen yıldız, üstte kundakta yatan İsa'nın üzerine indiği altta banyo yapan İsa'nın üzerine uzanmadığı görülür (Resim 30-31). Bazı örneklerde (örneğin Vatican Museum'daki Fildişi Levha'da olduğu gibi) altta banyo yaptırılan İsa'nın Meryem tarafından eliyle işaret edilerek gösterilmesi kutsallığın işareti olarak ifade edilir. 10. yüzyıldan itibaren İsa'nın doğumunda, Meryem'in İsa'ya fiziksel yakınlığı görülür. Örneğin, Hosios Loukas'taki İsa'nın doğumunda Meryem, yemliğin başına oturmuş, bir eli İsa'nın başında diğeri ise omzunda yer alır (Lazarides, 1987: 44, Fig. 25). Bizanslı sanatçılar doğum ve ölüm arasında tematik bütünlük kurmak için ikonografik verileri kullanmıştır. İsa'nın doğumu ve ölümü temalı tasvirlerde doğum mağarası-kaya mezarlık; yemlik-sarkofag; kefen-kundak gibi eşleştirmelerle sembolik bütünlük sağlanmış olur (Maguire 1977:138).

Matta ile Luka, Meryem ve Yusuf'un Beytüllahim'e geldiklerinde doğumun gerçekleştiğini yazar. Batı sanatında İsa'nın doğumunun tasvir edildiği örneklerde Matta ve Luka'dan esinlenilmiş olabileceği düşünülür. Iokabos'un Protoevangelion'u (18) ve Pseudo-Matta'da (13) İsa'nın doğumunun mağarada gerçekleştiği yazar. Bizans Sanatı ve Kapadokya duvar resimlerinde her zaman apokrif kaynaklarda anlatıldığı gibi mağara, ahır ve ev uygulamaları görülür (Jerphanion, 1925: I. 76 ).
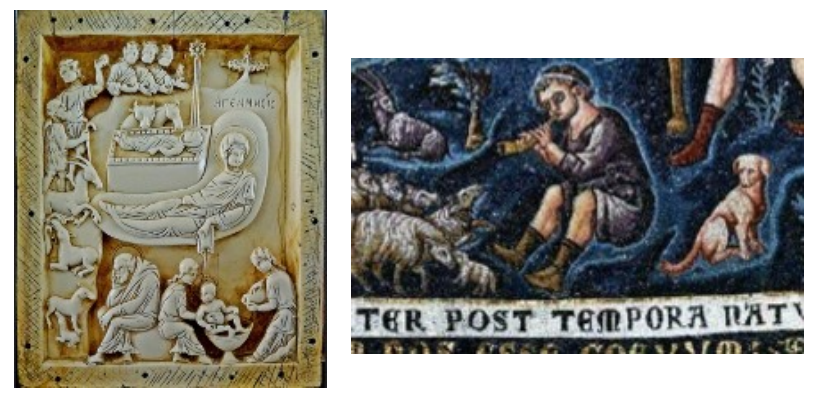

Resim 32. İsa'nın doğumu, 10.

Yüzyıl, Fildişi Levha,

Metropolitan Museum (sol)

Resim 33. Trestevere, Roma

Santa Maria Kilisesi, Apsis

Kemeri 1296-1300 (sağ)

(Salvador-Gonzalez, 2012: 8)

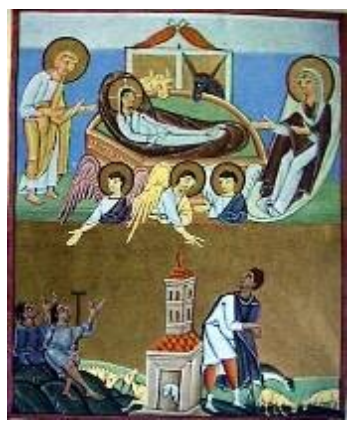

Resim 34. İsa'nın doğumu, Çobanlara Müjde,

Bamberg Apocalypse Yazması (Bamberg

Devlet Kütüphanesi, Msc.Bibl.140),

1000-1020, Otto Dönemi

Vatikan, Metropolitan ve Baltimore örneklerinde olduğu gibi Meryem, Yusuf ve İsa dişındaki figürlerin başında hale olmadığı görülür. Salome, Meryem tarafindan işaret edilir. 10. yüzyıldan itibaren İsa'nın doğumundaki çobanlar episodunda, flüt çalan genç bir çoban dikkat çeker.

Roma Santa Maria Kilisesi'nin (1296-1300) apsis kemerindeki figür buna örnektir. Kappadokia kiliselerindeki İsa'nın doğumu tasvirlerinde çobanların sürülerindeki 


\section{İsa'nın Doğumu}

hayvanların sırtında kırmızı lekeler görülür. Bu lekeler İç Anadolu etkisi olarak kabul edilir (Spitzing, 1989: 128-129) (Resim 32-34).
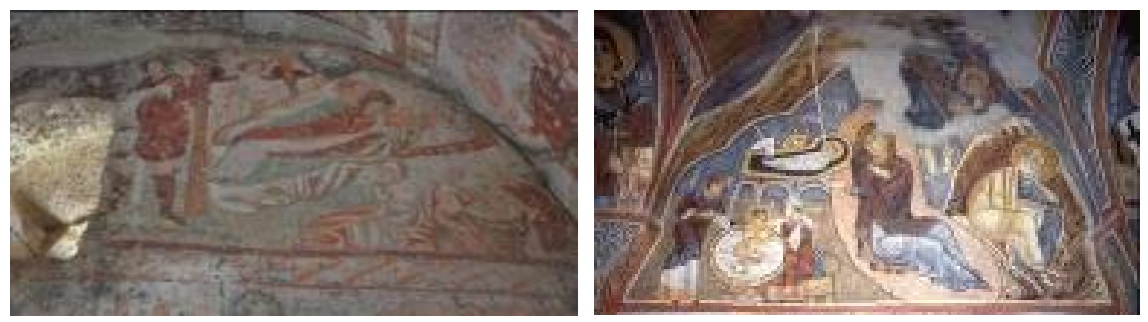

Resim 35. İsa'nın Doğumu, Çavuşin Ioannes Prodromos Kilisesi, 10.Yüzyıl (sol),

Resim 36. Karanlık Kilise, 11. Yüzyıl (Pekak Arşivi-2013)

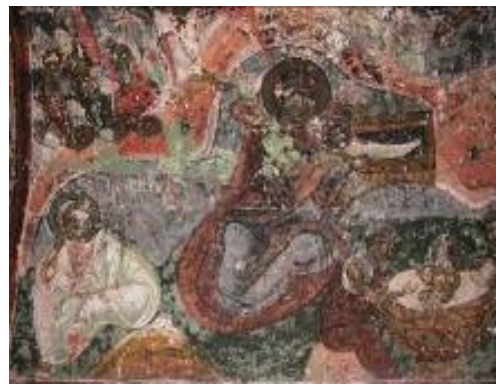

Resim 37. İsa'nın Doğumu, Karabaş Kilise 1060-1061 (Ataç Arşivi -2013)

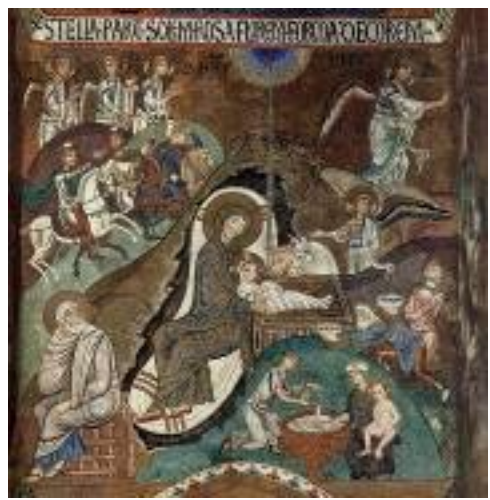

Resim 38. İtalya Palermo, Cappella Palatina, Güney Haç Kolu, Doğu Duvar, 1140-1170, Mozaik $^{17}$
Kompozisyonlarda Yusuf düşünceli şekilde otururur ve bir elini yüzüne dayamış derin düşünceler içinde (çoğunlukla sahnenin alt köşesinde) görülür (Resim 35-39). S1klıkla Yusuf'un karşısında bir figür görülür ve figür Matta'da Yusuf'un aklını çelmeye çalışan bir şeytan olarak yorumlanır ve Matta'da (1-19) Yusuf'un kafasındaki çelişkili sorular hakkında ayrıntılı bilgiler sunulur (Spitzing, 1989: 129).

\footnotetext{
${ }^{17}$ (http://www.thewestologist.com/arts/the-story-of-christ-s-birth-in-art 21.11.2015 - 23:59)
} 


\section{Sacit Pekak-Durmuş Gür}

726-842/3 İkonoklazm öncesi ve sonrasına tarihlendirilen kompozisyonlarda farklılık görülür. İkonoklazm sonrasında, kompozisyonlarda yoğunluk görülür ve episodlar arasında kontur yer alır. Konturlarda kırmızı ve beyaz tonlar hakimdir (Spitzing, 1989: 129). 1000 yılı sonrasında İsa'nın doğumu tasvirlerinde festival döngüsü görülür (Resim 40). Bu dönemden itibaren İsa'nın kutsallığı Meryem'in yerini alır. Kalabalık kompozisyonlarda bu uygulama çok net seçilir (Spitzing, 1989: 129). Batı sanatında ebelerin İsa'nın doğumunda tasvir edilmesi çeşitli zorlamalarla olmuştur. 1020 civarında Hildesheim'in bronz kapısı nispeten nadir uygulamalardandır. Tasvirde Meryem ve ayakta figürler görülmektedir (Sach, Badstübner ve Neumann, 1988: 142).

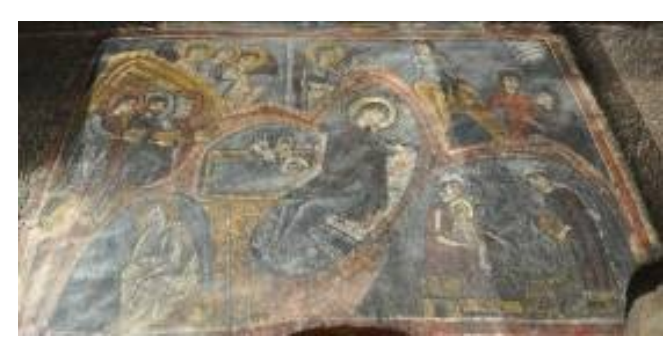

Resim 40. İsa'nın Doğumu, Niğde Eski Gümüş Manastırı, 12.-13.Yüzyıl (Pekak Arşivi-2013)

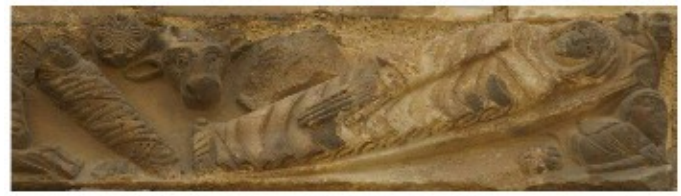

Resim 41. İsa'nın Doğumu, Le Bouleu Kilisei, Lento, 1160

İsa’nın doğumu ve ölümü günahkarları kurtarıcılığı doğrultusunda, çalıșmalarını simgeler. Bundan dolayı bazı kiliselerde yer ve gök arasındaki bağlantıyla ilişkilendirilerek tonozlara resmedilmiştir. Geç Bizans Dönemi kiliselerde tromplarda İsa'nın doğumu yer alır. Güneydoğu trompunda İsa'nın doğumunun tasvir edildiği kiliseler; Yunanistan Hosios Lukas (erken 11. yüzyıl), Yunanistan Daphni Kilisesi (11. yüzyıl sonu) ve Yunanistan Nea Moni Kilisesi'dir (11. yüzyıl) (Spitzing, 1989: 126).

Güney Fransa'da Perpignan civarında Le Boulou'daki kilisenin lentosunda İsa'nın doğumu (kabartma) tasvir edilmiştir. Merkezde öküz ve eşek, sağında Meryem solunda ise Meryem'le (V) oluşturacak şekilde kundaklanmış İsa tasvir edilmiştir. Yerel bir uygulama olan bu örnekte İsa'nın başında haçlı hale görülür. İsa'nın başı üzerinde yedi kollu yıldız betimlenmiştir. Meryem'in sol kolu bedeninin altında, kompozisyonun sağında ise Yusuf yer alır (Resim 41).

13.-14. yüzyıl sonrasındaki Batı Avrupa sanatında İsa'nın doğumu tasvirlerinde sembolik birçok unsur görülür. Meryem ve İsa arasında duygusal bağ öne çıkartılarak sembollerle sunulmuştur (Sach, Badstübner ve Neumann, 1988: 142). 

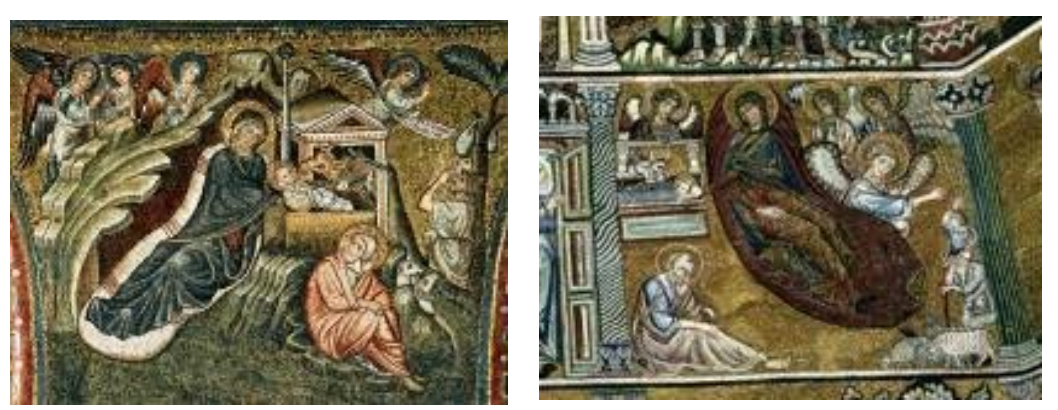

Resim 42. Roma Santa Maria Maggiore Kilisesi, Apsis Mozaik, 1296 (sol) ${ }^{18}$

Resim 43. Floransa, Battistero di San Giovanni Vaftizhane, Kuzey Duvar, İsa'nın Doğumu 1240-1300, Mozaik (sağ) ${ }^{19}$

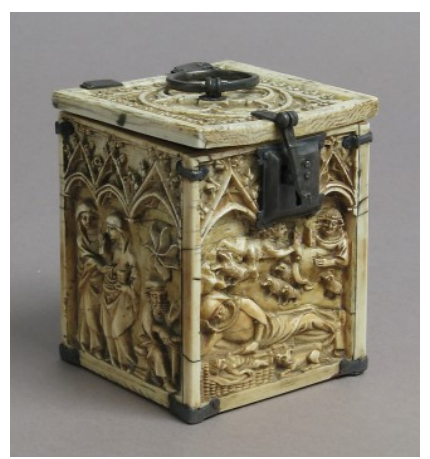

Resim 44. İsa'nın Doğumu, Fildişi Mahfaza Kutusu, 14. Yüzyıl, The Metropolitan Museum of Art

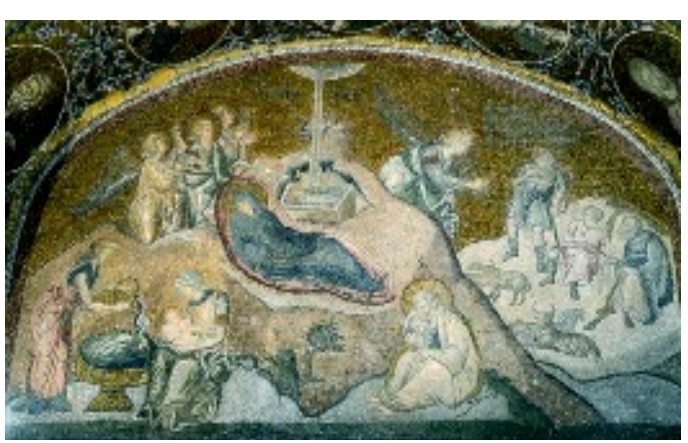

Resim 45. İsa'nın Doğumu, İstanbul Khora Kilisesi, Mozaik, 14. Yüzyıl (Pekak Arşivi-2010)

Batı sanatında doğum konulu tasvirlerde meleklerin İsa ve Meryem'in çevresinde neşeyle dans ederken görülür. İsa'nın yeryüzüne ilk gelişi sembolik unsurlarla ifade edilir, örneğin İsa'nın ilk doğuşu ile güneşin doğuşu özdeşleştirilir. Rönesans ve Barok dönemleriyle birlikte İsa'nın doğum tasvirleri daha gerçekçi resmedilmeye başlanır. Resimlerde daha çok karanlık ortamları aydınlatan 1şık ile İsa özdeşleştirilmiştir (Sach, Badstübner ve Neumann, 1988: 142).

Khora Kilisesi, İsa'nın doğumunda altın yaldız fon üzerine, mağaranın altında ebeler İsa'nın ilk bakımını yaparken tasvir edilmiştir. Mağaranın içinin karanlık bölümü çok ince biir hatla gösterilmiştir. Ioannes'in Protoevangelion'unda görülen mağara ve

\footnotetext{
${ }^{18}$ (http://www.wga.hu/html_m/t/torriti/mosaic/index.html 21.11.2015 - 23:49)

${ }^{19} \mathrm{http}: / /$ www.wga.hu/support/viewer_m/z.html 21.11.2015 - 23:59)
} 


\section{Sacit Pekak-Durmuş Gür}

meşale gibi sembolik unsurlar tasvirlerde sıkça işlenmiştir. Yunan mitolojisinde Doğum Tanrıçası Eileithia'nın meşaleyi taşıdığı sırada Thanatos'un (ölüm) tasvir edildiği görülür. Buradaki meşalenin de köken açısından benzerlik gösterdiği düşünülür (Spitzing, 1989: 130).

Yunanlar, yeni doğan bebeklerin yatırıldıkları minderlerin arasına sarımsak koyarak bu keskin kokuların iblisleri ve kötü kokuları dağıttıklarına inanmaktadır. Bu uygulamalar sadece Post-Bizans'ta zamanla uygulanmaya başlanmıştır. Geç Bizans Dönemi'nde parlak kırmızı maphorionuyla Meryem, tasvirlerde dikkat çeker (Spitzing, 1989: 130).

13.-14. yüzyıldan itibaren İsa'nın doğumu konulu sahnelerde realistik uygulamalar tercih edilmiştir. Buradaki örnek de gündelik yaşam mücadelesi içindeki bu olayın her türlü ayrıntısının yansıtılmaya çalışıldığı önemli örneklerden biridir.16. yüzyıldan itibaren sahnelerde çok fazla yoğunluk görülür bu da her dönem kompozisyonlara eklenen sembolik figürlerle açıklanabilir (Resim 42-46).

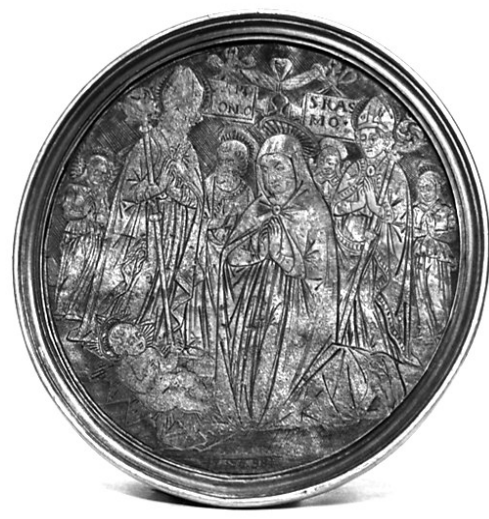

Resim 46. İsa'nın Doğumu, Gümüş Paten, 15. Yüzyılın İkinci Yarısı, Metropolitan Museum of Art

\section{DEĞERLENDİRME VE SONUÇ}

Yeni Ahit'e göre İsa'nın bu evrendeki yaşamı, günahkar insanlara ve iman edenlere Tanrı'nın Enkarnasyonunu hatırlatmak için önemli bir amaçtır. Meryem'in doğumu ile İsa'nın doğumuna altyapısal bir düzen oluşturulduğu düşünülmektedir. İsa'nın doğumuyla günahların ortadan kalktığı, hatta Hıristiyanların günahlarını yok etmek için Tanrı'ya kurban edildiğini inanılır. Ayrıca İsa'nın çarmıha gerilerek göğe yükselişi O’nun fiziki-ruhani durumuyla açıklanmaktadır. İsa'nın Meryem gibi et ve kandan insan bedeninde (ölümlü) şekillenmesi, Tanrı'nın ruhani doğasının yansıması olarak açıklanabilir. Ortodoks Hıristiyan inancına göre Tanrı'nın suretinde yaratılan insan (Tanrı tarafından yaratıldığı düşünülen Buda ve Tanrı'nın balçıktan şekillendirerek et ve kemiğe büründürdüğü Adem ve Havva) ilk günah ile kötülüğe 
sapar. Habil ve Kabil kardeşlerin arasında çıkan çekememezlik, sonuçta Kabil'in kardeşi Habil'i öldürmesiyle sonuçlanmış ve tüm dünyaya yayılmıştır (Vikan 2003: 235; Kalavrezou 2005:108; Coşkuner, 2009: 53).

Martin'den doğrudan aktaran Coşkuner, İsa'nın doğasını tüm çıplaklığıyla ortaya serer;

"Insanoğluna duyduğu sevgi ve sonsuz merhametinden, Rab ölüme mahkum olan doğayı çürümekten kurtarıp, asıl mutlu durumuna getirmek istedi... Bu yüzden bedensel ölüme teslim oldu... çünkü belki, o zaman Adem "in günahını kendi içinde eritebilirdi" (Martin, 1955: 194; Coşkuner, 2009: 54).

Tüm bu kötülüklerin sürüp gitmesiyle Tanrı, insanoğlunu kurtarmak için İsa'nın bedeninde et ve kemiğe bürünerek saf ve temiz ruhlu Meryem'in bedeninden lekesiz bir şekilde dünyaya gelir. Tanrı, doğum sürecinde özüyle ilahi yansıması olan insani doğasını birleştirmiştir. Yaşam sürdükten sonra ölümü ve tekrardan dirilişiyle yeryüzündeki uyarıcı ve öğretici Hıristiyanlık düşüncesini evrende sürekli kılmıştır (Vikan, 2003: 235).

Acara, Bizans Dönemi’nde doğumların Meryem, Vaftizci Yahya'nın İsa'nın doğumuyla ifade edildiğini yazar. Ayrıca tasvirlerde bu kutsal üç doğumun ikonografik ayrıntıları üzerinde durulmaktadır. Halk arasında uygulanan doğum litürjisi hakkında bilinenler sınırlıdır. Bizans Dönemi’nde doğum işlemlerinin çoğunlukla evde hizmetçi kadınlar yardımıyla gerçekleştirildiği bilinir. Bunların dışında doğumların gerçekleştirildiği özel mekanlar ve hastaneler de vardır (Acara, 1998: 186).

Karpozilos, Kazhdan ve Cutler, Ioannes Eleemon'un Vitası'na dayanarak İskenderiye'de doğum işlemlerinin gerçekleştirildiği tıbbi yapıların varlığı bilinir (Karpozilos, Kazhdan, Cutler, 1991: 290). Araştırmacılar doğum sonrasında (tıpk1 günümüzdeki gibi) bebeklerin yıkanarak kundaklandığını belirtir. Doğum yapanın temiz olmadığını kabul eden araştırmacılar kadının, doğumun üzerinden 40 gün geçtikten sonra Ökaristi'ye katılabildiğini belirtmektedir (Karpozilos, Kazhdan, Cutler, 1991: 290).

Maguire, İsa'nın Adem ile dünyaya günahın tanıtıldığını, İsa ile evrenin günah ve kötülüklerinden arındırıldığını yazar (Maguire 1996: 20). 726-842/3 İkonoklazm sonrasına tarihlendirilen İsa'nın doğumu tasvirleri İsa'nın fiziki yapısının ispatıdır. $\mathrm{Bu}$ görüşü savunanların başında Konstantinopolis Patriği Nikephoros (758-828/806-815), Konstantinopolis Studios Manastırı Hygomeni Theodoros (759-826), Nikomedialı Georgios (9.yüzyıl), Symeon Metaphrastes (10. yüzyıl) gibi ikonodüllerin yazdıkları litürjik metinlerde ikonoklastlara karşı çıkılır (Sinkevic, 2000: 51).

İsa'nın yaşamının doğum, ölüm gibi evrelerini sembolize eden litürjik eserler Bizans sanatında büyük öneme sahiptir (Acara, 1998: 196). Londra British Museum'daki Fildişi Kutu, Monza Amullası (Frazer, 1979: 565-566, Fig. 79), Bobbio Ampullası, Sancta Sanctorum ahşap paneli, Rabbula İncili fol.13r'deki gibi 5.6.yüzyıllara tarihlendirilen Erken Bizans Dönemi'nden sonra İsa'nın doğumu ve çarmıhta İsa tasvirleri bir arada görülür. Orta Bizans Dönemi’nde, çarmıh ile İsa'nın 
doğumu birbirlerini tamamlayan sahneler olarak resim programlarında yerini alır (Weitzmann, 1974: 33; Kartsonis, 1986: 31-33) (Resim 47).

\section{Ebeler (Salome, Zelomi ve Mea)}

İsa'nın doğumu ve ilk banyosu, bazı kompozisyonlarda bir arada bazılarında ise ayrı tasvir edilmiştir. İsa'nın doğumunda görülen ebeler bazı değişikliklerle birlikte Akhilleus, Dionysos, İskender'in doğumu kompozisyonlarındaki ebelerle benzemektedir. Ortak tasvir anlayışı ya da etkileşimin sonucu olduğunu gösterir. İsa'nın ilk banyosunda görülen kompozisyon, figür ve üslup anlayışı Yunan, Roma, Bizans ve Avrupa örnekleri incelendiğinde büyük bir etkileşimin olduğunu göstermektedir. Bunlardan öne çıkan Salome'nin elindeki kaptan (testi-ibrik-sürahi) banyo havuzuna sürekli su boşaltması ve su haznesi gibi birçok ayrıntının benzerlik gösterdiği görülür.

İsa'nın ilk banyosu tasvirlerinde, kompozisyonun sağında ve ayakta betimlenen Salome, elinde testi-ibrik ile İsa'nın banyo havuzuna ya da üstüne su boşaltırken betimlenmiştir (Resim 48-49). Diğer ebe ise İsa'yı ya kucağında tutmakta ya da su havuzunun içinde onu yıkarken tasvir edilmiştir. Bu ebenin adı apokrif kaynaklara göre resmedildiği bilinen Kappadokia kiliselerinde Mea olarak tanımlanır. Mağaranın dışında sağ üstte ise elini çobanlara uzatan melek görülür (Önen-Alev, 2014: 3742).

Tritsaroli ve Valentin Bizans Dönemi’ndeki doğum, vaftiz, ölüm ve gömü işlemleri üzerinde imcelemeler gerçekleştirmiştir. Huristiyanlar'ın bu işlemlerin sosyal ve dini uygulamalarla ilişkili olduğu düşünülmektedir. Bizans Dönemi’nde doğum işlemlerinin çoğunlukla evde birkaç ebe, akraba ya da arkadaş yardımıyla gerçekleştirilmektedir. Koukoules,

Tritsaroli ve Valentin Bizans Dönemi'nde yeni doğan bebeklerin doğum sonrasında yıkanarak temizlendiğini (Tritsaroli ve Valentin, 2008: 94, Koukoules, 1951: 29) (Resim 50) ayrıca doğum sonrasında yıkanan bebeklerin bedenlerinin düzgün

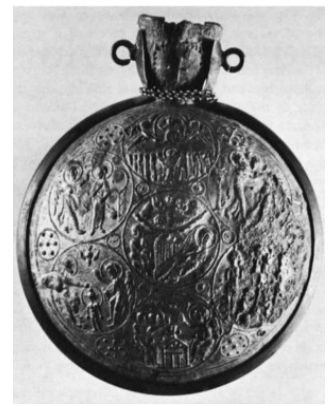

Resim 47. İsa'nın

Doğumu, Monza

Ampullasi, Monza, Kathedral Treasury, 603613 (Frazer,1979: 566, Fig. 79)

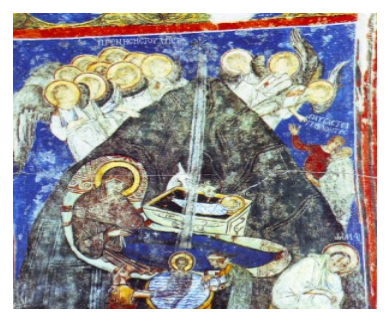

Resim 48. İsa'nın Doğumu,

Göreme Tokalı Kilise, 10. Yüzyıl (Pekak Arşivi)

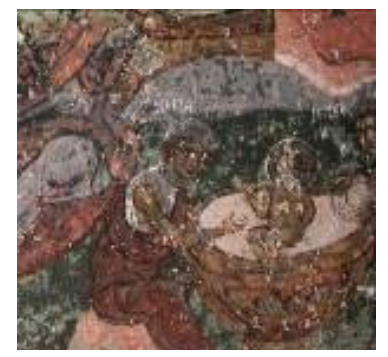

Resim 49. İsa'nın Doğumu, Karabaş Kilise 1060-1061 (Pekak Arşivi-2012) 
ve güzel kılınması için 7 gün boyunca yün sargı ile sarmalandığını (kundaklandığını) belirmektedir (Tritsaroli ve Valentin, 2008: 94). Ayrıca doğum sonrasındaki 40 günlük süreçte bebek ve annesi kirli kabul edilir ve litürjiye dahil edilmezler, kötü ruhlara sahip olduklarına inanılarak rahipler tarafından çeşitli işlemlere tabi tutulur (Koukoules, 1951: 33-34; Tritsaroli ve Valentin, 2008: 94). Yeni doğan bebeklerin hemen vaftiz edilmesi durumunda ölüm riski taşıdığını belirten araştırmacıların 40 gün durumunun litürjik olmasının yanında çeşitli fiziki amaçlarının da olduğunu savunur (Tritsaroli ve Valentin, 2008: 95).

Bizans Dönemi'nde her kadın evinde doğum yapacak diye bir zorunluluk yoktur çünkü İsa'nın doğum işlemini gerçekleştiren bakire Meryem bunun güzel bir örneğidir. Zorunlu doğum işlemleri ve bebek bakımları için Bizans Dönemi'nde yetimhaneler (orphanotropheion) ve doğumhaneler (brephotrofeion) bulunmaktadır. Bu uygulamalar ilk defa 5. yüzyılda Theodosius Kodeksi'nde daha sonra 6. yüzyılda Iustinianus Kodeks'inde belirtilmiştir. Doğum sonrasında bebekler, anneleri ya da bebek bakıcıları tarafından büyütülmektedir. İlk altı ay anne sütü ile beslenen bebeklerin şarap, bal, su, keçi sütü gibi çeşitli karışımlardan elde edilen ürünlerle beslendikleri bilinmektedir. Doğum sonrasından iki ya da üç yıl kadar çocukların hastalık durumlarına göre sütten kesildikleri bilinir. Ayrıca emzirme uygulamasının da ailelerin sosyo-ekonomik durumu ile ilişkili olduğu görülür. Aristokrat kadınlar bu tarz durumlar için bir ya da daha fazla yardımıı kadın çalıştırmıştır (Tritsaroli, Valentin, 2008: 94-95).

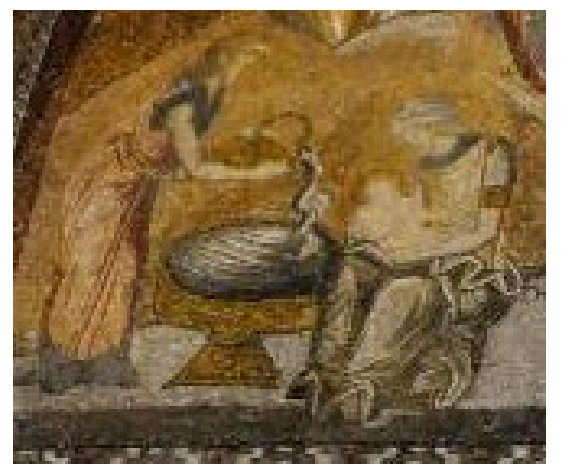

Resim 50. İstanbul, Khora Manastırı Kilisesi, 14. Yüzyıl, İsa'nın Doğumu (Pekak Arşivi-2010)

Doğum sonrasındaki ilk banyo ile vaftiz arasındaki lituriyi inceleyen Arad, İsa'nın ilk banyosunun Bizans sanatında 6 . yüzyılda ortaya çıktığını ifade eder. $\mathrm{Bu}$ uygulama Apokrif ve Kanonik kaynaklarda geçmemektedir. İlk banyonun kaynağının Helenistik ve Roma sanatındaki bir bebeğin yaşam döngüsü içinde incelenmesi gerekebilir. İlk banyo Akhilleus, Dionysos ve İskender'in tasvirlerinde görülmektedir. İlk banyo uygulamalarında zamanla birçok ayrıntı görülür, suyun sıcaklığını test eden ve bebeğin k1yafetlerini elinde tutan ebeler buna örnektir (Arad, 2003: 22). İsa'nın ilk banyosu kanonik kaynaklarda geçmemesine rağmen tasvirlerde görülür. İsa'nın vaftizi kanonik kaynaklarda geçmektedir (Matta, 3: 13-17; Markos, 1: 911; Luka, 3: 21-22; Yuhanna, 1: 29-34). Doğumdaki Emmanuel İsa tanımlaması vaftizle ilişkilendirilir. Vaftiz ve ilk banyo Tanrı'nın varlığına işaret eden sembolik ayrıntılardır (Matta, 3: 17; Markos, 1:11; Luka, 3:22, Arad, 2003: 24). Vatiz sahnelerindeki banyo motiflerini inceleyen Arad, Salome'nin kompozisyonlarda Doğu'da 6. yüzyıl, Batı'da 


\section{Sacit Pekak-Durmuş Gür}

ise 7. yüzyıldan itibaren yer almaya başladığı belirtir (Arad, 2003: 29).

İsa'nın ilk banyosuyla vaftizi arasında ilişkiyi inceleyen Arad, bunun duvar resimleri ve küçük el sanatlarında görüldüğünü ifade eder. Bu ilişkinin yazılı kaynaklarda anlatıldığı gibi olmadığını belirten araştırmacı, Ortaçağ sanatında belirgin olduğunu yazar. 12. yüzyıla tarihlendirilen Katalonya, Aragon, Roussillon, Provence ve Languedoc örneklerini inceleyen araştırmac1, bu dönemde Kuzey İspanya ve Güney Fransa arasındaki kültürel etkileşimi vurgular (Arad, 2003: 33-34).

Bologna'da 7. ve 8. yüzyıla tarihlendirilen fildişi örnekteki İsa'nın ilk banyosundaki ebe, hazırlık işlemleri için beklemektedir. Roma San Valentino Katakombu'nun 7. ve 8. yüzyıla tarihlendirilen duvar resimlerinde, Sina'da 8. ve 9. yüzyıla tarihlendirilen resimlerde İsa'nın ilk banyosu görülmektedir. Burada diğerlerinden farklı olarak Salome kompozisyona dahil edilmiş ve yazıyla açıklanmıştır. Bu yazıt aynı zamanda doğuş ikonografisi'ndeki Salome ile İsa'nın ilk banyosunun meşrulaştırılmasıdır. 9. yüzyıldan itibaren artan Salome tasvirleri 11. yüzyıldan itibaren yaygın bir şekilde kullanılmıştır (Arad, 2003: 29).

\section{Yusuf}

Yusuf, İsa'nın doğumu tasvirlerinde 5. yüzyıldan itibaren görülmektedir. Doğum sonrasında Yusuf, Meryem'in bakire olduğunu vurgulamak için Meryem'in bitişiğinde ya da mağaranın içinde değil genellikle mağaranın dışında ve düşünceli bir şekilde tasvir edilmiştir. Bu uygulama İtalyan resimlerinde çok fazla görülmektedir (Salvador-Gonzalez, 2012: 28).

İsa'nın doğumu tasvirlerinde merkezde İsa, yakınında Meryem ve Yusuf yer alır. Meryem tasvirlerde şilte üzerinde uzanır ve bu uygulama İskender ve Dionysos gibi antik doğum tasvilerinde de görülür (Wilhelm-Red, 1994: 95), Yusuf, çoğunlukla İsa'nın yakınında, kompozisyonda Meryem'i dengelemektedir. Meryem, genellikle başını bir eli ile destekler, gözü ya da eliyle İsa'yı işaret eder ya da O'na sarılır. Böylece O’na yakınlığını vurgular. Yusuf tasvirlerde çoğunlukla elinde meşaleyle ayakta, bir eliyle ya da gözüyle İsa'ya yönelirken görülür. Kompozisyonun merkezindeki İsa, Meryem ve Yusuf üçlüsünden, Yusuf'un duruş ve konumunda bazı değişiklikler görülür (İsa’ya bazen arkasını döner bazen de sadece başı ile yönelir).

Yusuf ile söylenebilecek önemli bir husus ise sahnenin betimlenmesinde kullanılan kaynaktır. Çünkü anlatılanlara göre Yusuf (bazen de Yusuf'un çocukları) doğum sırasında Meryem'in yanında yer almaz. Doğum sırasında ebe aramak için Meryem'in yanında ayrılır. Bundan dolayı da erken örneklerde Yusuf'un kompozisyonda yer almamış olabileceği düşünülür. Yusuf çoğunlukla tasvirin alt köşesinde, olayın şaşkınlığını ve aldatılma düşüncesini içinden atamadığının göstergesi olarak düşünceli şekilde otururken ya da ayakta betimlenmiştir. İsa'nın ilk banyosu tasvirlerinde Yusuf, çoğunlukla İsa'ya arkası dönmüş bir şekildedir. Bazen arkasına dönerek İsa'ya bakmakta bazen de kafasını önüne eğerek olayın derin düşüncesini yaşamaktadır. Bazı örneklerde de Yusuf'un, banyo yaptırılan İsa'yı izlediği görülür (Salvador-Gonzalez, 2012: 28).

\section{Sanat Tarihi Dergisi}




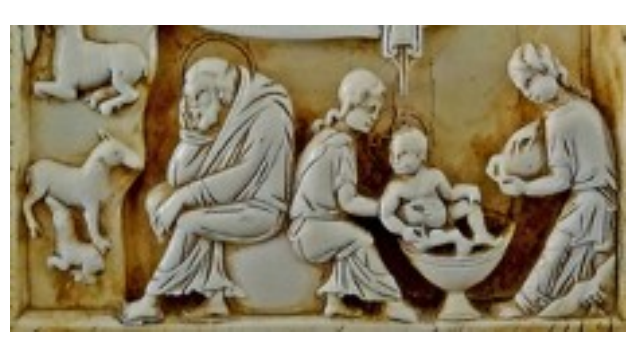

Resim 51. İsa'nın Doğumu, 10. Yüzyı1,

Fildişi Levha, Metropolitan Museum of Art

10. yüzy1la tarihlendirilen Metropolitan Museum'daki fildişi levhada, ebeler tarafından banyo yaptırılan İsa'nın, hemen üstündeki Meryem, kompozisyonun altındaki banyo yaptırılan İsa'yı sol eliyle işaret etmektedir. Meryem tarafindan gösterilen İsa, arkasını dönerek Yusuf'a bakar. Bu uygulama, tasvirdeki sürekliliği gösterir. $\mathrm{Bu}$ kompozisyon anlayışı, sinematografik uygulamayı düşündürür. Dönem, bölge ve sanatçıya göre farklılık gösteren bu gibi uygulamar episod düzenini güçlü kılar (Resim 51).

\section{Kutsal Hayvanlar (Öküz ve Eşek)}

İsa'nın doğumu tasvirlerinde öküz ve eşek gibi kutsal hayvanların Erken Dönem'den itibaren tasvir edildiği görülür. Sembolik iki hayvan çoğunlukla İsa'nın başucunda ya da ayakucunda yer almaktadır. Hayvanlar İsa'nın doğduğu alanın ahır olduğunu vurgulanmak için kullanılmış olabilir. Ayrıca doğumun gerçekleştiği soğuk ortamda bebek İsa'nın öküz ve eşeğin nefesleriyle 1sıtılmış olabileceğini düşünülür (Spitzing, 1989: 127; Sach, Badstübner ve Neumann, 1988: 141).

Öküz ve eşeğin resimlerde kullanılmasının Yahudi-Hıristiyan ve PaganHıristiyan uygulamasının bir parçası olduğunu düşünülür (Spitzing, 1989: 127). İsa'nın doğumunda zamanla (daha çok Avrupa resminde) koyun, kuzu ve köpek gibi çeşitli hayvanlar da görülür. Avrupa resmindeki kalabalık kompozisyonlardaki hayvanların Erken Bizans Dönemi örneklerinde işlenmediği bilinir. Ayrıca doğumundaki çobanlar meşrulaştırılmak için çevresindeki hayvanların sayılarında artış olmuştur (SalvadorGonzalez, 2012: 31-32).

Öküz ve eşek tasvirlerine Iokabos'un Protoevangelion'u, Pseudo-Matta ve Eski Ahit Peygamberleri'nin söyledikleri kaynaktır. Iokabos'un Protoevangelionu'nda, İsa'nın Çocukluk İncili'nde ve Pseudo-Matta'da doğumun bir mağarada gerçekleştiği, üç gün sonra ahırdaki öküz ve eşeğin arasında bir yemliğe yatırılarak Meryem ve Yusuf'la burada üç gün kaldığı anlatılır. Ayrıca doğumun Barnabas İncili'nde çoban barınağında gerçekleştiği yazmaktadır.

Schiller, doğum ikonografisindeki eşek ve öküzün, Antik Dönem tasvirlerindeki mitolojik hayvan bakıcılarıyla ilişkilendirmektedir. Kilise babalarından Ambrosios (339-397) ve Augustinus (354-430)'a göre öküz seçilmiş Yahudi halkını, eşek ise kafirleri sembolize etmektedir. Gregorios, öküzün, kanunların uygulamaları altındaki insanları, eşeğin ise putperesliğin günahlarıyla dolu Tanrı'nın oğlunu yalanlayan insanları temsil ettiğini yazmaktadır. Schiller öküzün günahsız insanları, eşeğin ise günahkarları temsil ettiğini ifade etmektedir (Schiller, 1971: 60). 


\section{Sacit Pekak-Durmuş Gür}

\section{Bakireliğin Önemi ve Meryem'in Bekareti}

Evadne, Leda ve Meryem gibi bakire kadınların Tanrı çocuklarını doğurmak için seçildiklerini belirten Blank, Apokrif kaynaklarda Salome'yi Meryem'in bekaretinden şüphe duyarak bekaret testi uygulamaya çalıştığında Salome'nin elinin kuruduğu anlatılır. Bakirelerin sihirli ve kutsal varlıklar olduğu kabul edilir (Blank, 2008: 143). İsa'nın, Meryem'in rahmine düştüğü anda görülen uysal itaakarlık, cennetin cinsel içgüdüden yoksun ve Meryem'e karşı duyulan bekaret saygısının bedenden çok zihinde yer aldığını kanıtlamaktadır (Blank, 2008: 224).

Büyük Perhiz olarak tanımlanan kefaret döneminde Hamsin yortusunda ve Noel'den önceki dört hafta boyunca ve Çarşamba günleri (İsa'nın yakalanması), Cuma günleri (İsa'nın ölümü) ve Cumartesi günleri (Meryem anısına) da çiftlerin cinsel ilişkiden kaçınması manastır içinde olduğu kadar halk için de geçerlidir (Blank, 2008: 235).

Ortaçağ'ın vazgeçilmezi kabul edilen Meryem hakkında bilinenler apokrif ve kanonik kaynaklara dayanır. Luka'da az da olsa Meryem'e yer verilmiştir. Markos'ta Meryem adına sadece iki defa yer verilmiștir. Yuhanna'da ise, Meryem'in adından bahselmemektedir. Roma Katolik Kilisesi'nin en ünlü kadın şahsiyetine (ve İsa'dan sonra önemli insan şahsiyeti) ilişkin ifade ettiği dört dogma maddesinden sadece birisi (İsa'yı doğurması) kutsal kitapla doğrulanabilir. Lekesiz bekaret (4. yüzyıl), hamilelik (1854) ve cennete yükselmesi (1950)'de Papalık kararıyla kabul edilir. Luka ve Matta'da Meryem'in bekaretine ilişsin kesin ifadeler bulunur. Luka ve Matta karşılaştırıldığında Luka'nın Meryem hakkındaki ifadeleri daha üstün kabul edilir (Blank, 2008: 247-248).

Luka'da, müjde için gelen Gabriel'e Meryem şunları söyler;

“Ama bu nasil olabilir, bana tek bir erkek eli değmedi ki?".

Meryem'in bekareti Hıristiyanlık'taki karşıt görüşü yok edebilecek masum ve saf bir ifadedir. Ayrıca Matta'da Meryem ile Yusuf'un evlenmedikleri, ilişki yaşamadıkları şöyle anlatılır;

"bir araya gelmesinden önce Kutsal Ruh tarafindan hamile kaldı $\breve{l} l "$ (Blank, 2008: 248). Wamer'in de ifade ettiği gibi İsa'nın doğumuyla Yunan-Pagan geleneği olan Parthenios (büyüdüğünde yüce, hatta mucizeler yaratan Tanrı ve yarı insanoğlu) arasındaki benzerlikler, Erken Hıristiyanlık Dönemi’nde tartışmalara sebep olur (Blank, 2008: 249-250). 4. yüzyılın sonunda İsa'nın “Bakire Meryem aracılı̆̆ıyla Kutsal Ruh tarafindan yaratıldığını” düşüncesi Hıristiyanlığın ortak görüşüdür. 390'da Papa Siricius, Meryem'in bekaretinin hamilelik ve doğum sirasında (in partu) bozulmadığını ilan etmiştir. Origenes ve İskenderiyeli Klement, Meryem'in bekaretini Iokabos'un Protoevangelionu'na dayandırır ${ }^{20}$. 8.-9. yüzyılda Latince olarak yayınlanan

${ }^{20}$ Origenes ve Klement için bakınız; (Osborn, 1957; Chadwick, 1980; Cosaert, 2008; Yılmaz, 2015: 98-108).

\section{Sanat Tarihi Dergisi}


Pseudo-Matta ve Meryem'in Doğumu İncili, Meryem'in kutsallığına büyük etki etmiştir (Blank, 2008: 250-251).

Iokabos'un Protoevangelion'u, Meryem'in doğumu ile başlamaktadır. Bu uygulama daha sonra birçok doğum örneğinde görülen birçok kutsallığ 1 da beraberinde getirmiştir. $\mathrm{Bu}$ doğum uygulaması daha önce Sara ve İbrahim'in doğumunda görülmektedir. Anna çocuğu olması için Tanrı'ya dua eder ve bunun üzerine Tanrı tarafından gönderilen melek, Anna ve Joachim'e bir çocukları olacağını bildirir. Büyük sevinç yaşayan Anna ve Joachim birbirlerine sımsıkı sarılır ve Anna hamile kalır. Bu sarılma anı Ortaçağ resimlerinde sıkça görülür. Meryem'in bu şekilde cinsel birleşme olmaksızın hayata gelmesi İsa'nın doğumuna hazırlıktır (Blank, 2008: 251).

Bakire Meryem kavramı Ortaçağ'dan kalma büyük ve karmaşık bir mirastır. Bekareti ve anneliğine bağlı onuruyla Tanrı katında kutsal kabul edilerek tasvir edilir. Bekaret kavramı Meryem'in ruhani mükemmelliğinin yansımasıdır(Blank, 2008: 258).

\section{Yıldız}

İsa'nın doğumu ikonografisinde zamanı gösteren iki ayrıntı bulunur. Bunlardan biri, Pseudo-Matta ve Iokabos'un Protoevangeliumu'nda doğumun öğleden sonra gerçekleştiği ifade eden zaman kavramıdır. Diğeri ise tasvirlerde görülen ve apokrif kaynaklarda ifade edilen gökteki kutsal yıldızdır. İsa'nın doğumu tasvirlerinde 3.-4. yüzyıldan itibaren yıldız, O’nun kundağı üzerinde yerini almıştır.

Tasvir edilen mekana göre kompozisyonda yıldızın konumu değişmektedir. 4. yüzyıl örneklerinde kundaklanmış İsa üzerinde yıldız ve kutsal hayvanlar görülür. Mağara içindeki doğum tasvirlerinde, yıldız mağara üzerinde ya da karanlık mağara içinde tasvir edilir. Kompozisyondaki tasvir düzenine göre yıldızı işaret eden sembolik figürlerden çobanlar, Müneccim Krallar, Meryem ile Yusuf çeşitli duruş ve şekillerde bir eliyle yıldızı işaret etmektedir. Müneccim Krallar'ın yeni doğmuş bebek İsa'yı bulmaları için gökyüzünde beliren ve yolculukları sırasında onlara eşlik eden yıldız, Müneccim Krallar'ın tapınmasında ya da doğumun gerçekleştiği kompozisyonlarda sembolik unsur olarak görülür.

Müneccim Krallar siklusunun parçası olan yıldız, doğum tasvirlerinde krallar olmadan da betimlenmiştir. Matta'da $(2,9)$ yıldız bir evin üzerinde parlarken Protoevangelion'da (21) mağaranın üzerinde yer alır. Müneccim Krallar siklusunun bir parçası olmasına karşın 5. yüzyıla tarihlenen Ravenna Başpiskoposu Maksimianus'un fildişi katedrası gibi erken örneklerden itibaren yıldızın tek başına görülmesi Eski Ahit, Yeni Ahit, Yuhanna'nın Vahyi ve litürjik metinlerde İsa'nın doğum sembolü olarak kabul edilir (Kalokyris, 1969: 88-89).

İsa'nın doğumu sırasında yıldızın parladığı ve doğum için gelen ebelerin korkarak mağara önünde bekledikleri Matta, Pseudo-Matta ve Iokabos'un Protoevangeliumu'nda vurgulanmıştır. Çalışma kapsamında incelenen ve İsa'nın doğumu tasvirlerinin vazgeçilmez unsuru olarak tüm betimlerde yerini alan yıldız, duvar resimleri, mozaik ve Ortaçağ resimlerinde, çoğunlukla beyaz, şeffaf ve parlak bir 1şık şeklinde görülür. Litürjik metinlerde ayrıntılı bir şekilde incelenen yıldız, zamanla 


\section{Sacit Pekak-Durmuş Gür}

tasvirlerde iki defa betimlenen İsa'nın vurgulanmasında (kundakta İsa ve ilk banyo uygulamalarında) kullanılmıştır.

İsa'nın doğumu ikonografik, tarihsel ve üslup açısından birçok anlam taşır. İsa'nın Meryem tarafından doğrulması onun insan-beşeri bir bedene sahip olduğunu gösterirken herhangi bir ilişkiye girilmeden, bakire Meryem tarafindan doğumunun gerçekleşmesi O’nun Tanrısallığının göstergesidir. Ayrıca bu yönüyle İsa; Asur (Adad), Yunanistan (Adonis, Apollon ve Zeus), Hindistan (Agni), Thebes (Alcides/Hercules), Frigya (Attis), Finike (Baal), Afganistan (Bali), Hindistan, Çin ve Japonya (Buda/Beddhu), Siam Deva Tat (Buda), Druidler (Hesus), Misır (Horus, Osiris ve Serapis), Tibet/Hindistan (Indra), Nepal (Jao/Iao), Hindistan (Krishna), Shintos (Mikado), Pers (Mithra), İskandinav (Odin), Kafkasya/Yunanistan (Prometheus), Meksika (Quetzalcoatl), Burma (Salivahana), Suriye (Tammuz), Galyalılar (Thor), Sibyls (Evrensel Monarch), Bilingonese (Wittoba), Trakya (Zamolxis/Zamolxis), Pers (Zerdüşt/Zerdüşt) gibi çeşitli kültür ve inanış biçimleriyle etkileşimini gösterir (Acharya ve Murdock, 2011: 8-9).

Bütün bu etkileşim ve doğum örnekleri onun fiziki yapısının yanında Tanrı olduğunun da göstergesidir. İsa'nın Tanrı yapısı Yeni Ahit’teki şu sözlerle anlatılır;;

“Iman ediyorum ki, İsa Mesih Tanrı'nın Oğlu'dur” (Elçilerin İşleri, 8: 36-37). Baba'nın yüceliği sayesinde Mesih nasıl ölümden dirildiyse biz de yeni bir yaşam sürmek üzere vaftiz yoluyla O'nunla birlikte ölüme gömüldük” (Pavlus'tan Romalılar'a Mektup, 6: 4).

Mezheplerin çeşitli görüşlerine karşılık, İsa'nın doğumu, insan doğasıyla açıklanır (Spitzing, 1989: 124). Doğumun gerçekleştiği mekan aslında İsa ve Meryem'in sosyal ve ekonomik durumları hakkında bilgiler sunar. Her ne kadar çelişkili olsa da yemlik, mağara, ahır, ev ve han, İsa'nın doğumunun gerçekleştiği mekanlar olarak karşımıza çıkar. Avrupa resminde, doğum ev ve han gibi alanlarda gerçekleşir, apokrif kaynaklarda ise daha çok mağara ve çoban barınağı görülür.

Antik Dönem, Roma ve Bizans'ta çoğunlukla ev, ahır, mağara ve handa gerçekleşen doğum uygulamalarında ebelerin yer aldıkları görülür. Doğum kompozisyonlarının kalabalıklaşmasıyla tasvirlere eşek ve öküz gibi kutsal hayvanların yanında çobanlar, Melek (ler) ve Müneccim Krallar'ın eklenir ve böylelikle doğum ile episodlar meşrulaştırılmaya çalışılır. Ayrıca İsa'nın doğumunun Eski Ahit’te şöyle müedelendiği ifade edilir;

"Rabbin kendisi size bir belirti verecek: işte klz gebe kalıp bir oğul doğuracak; adını Immanuel koyacak" (Eski Ahit, 7: 14).

İşaya peygamberin dışında Hoşea Peygamber de İsa'nın doğumunu Eski Ahit'te şöyle müjdelemektedir;

“İki hayvanın ortasında kendini göstereceksin" (Eski Ahit, 11: 1).

Maguire, İsa'nın Adem ile birlikte dünyaya günahın tanıtıldığını, İsa'nın yaşamı ve ölümü ile birlikte de günahtan ve kötülüklerden arındırıldığını yazar (Maguire, 1996: 20).

\section{Sanat Tarihi Dergisi}


İsa'nın doğumu ve günahın ölümü eşdeğer kabul edilir. Bütün bunlar doğrultusunda, el sanatlarında ve kiliselerde İsa'nın doğumu ve çarmıhta İsa tasvirleri bir arada verilmeye çalışılmıştır. Kappadokia kiliselerinde bu iki tasvirin çoğunlukla karş1lıklı resmedildiği görülür ${ }^{21}$;

"Artık günaha kölelik etmeyelim diye, günahlı varlı̆ımızın ortadan kaldırılması için eski yaradılışımızın Mesih'le birlikte çarmı ha gerildiğini biliriz (Pavlus'tan Romalılar'a Mektup, 6: 6). Mesih'le birlikte ölmüsssek, O'nunla birlikte yaşayacağımıza da inaniyoruz" (Pavlus'tan Romalılar'a Mektup, 6: 8).

\section{Müneccim Krallar}

Doğum tasvirlerinin gelişmiş ikonografisinde görülen Müneccim Krallar (Kahin Krallar, Kahinler, Bilge Adamlar, Müneccimler, Müneccim Krallar, Doğu'dan Gelenler, Ü̧̧ Müneccim) Pseudo-Matta'da anlatıldı̆̆ı kadarıyla doğumdan iki yıl sonra tapınmaya gelmiştir. Kalokyris, Müneccim Krallar'ın tapınmasıyla 25 Aralık'ta İsa'nın doğumu yortusuyla litürjide kutlandığını yazmaktadır (Kalokyris, 1969: 85).

Kaynaklarda ayrıntılarıyla sunulan figürler zamanla Müneccim Krallar episodunun oluşmasına yardımcı olmuştur. Genel siklusa bakıldığında Müneccim Krallar'a yıldızın görünmesi, Müneccim Krallar'a meleğin yol göstermesi ve Müneccim Krallar Hirodes'in huzurunda, Müneccim Krallar'a meleğin görünmesi ve Müneccim Krallar'ın geri dönüşü tasvirlerde yerini alır. Ancak bu siklustan doğuma dahil edilen episodlar (tasvirlerde sıkça görülen) Müneccim Krallar'ın yıldızı takip etmesi veya Müneccim Krallar'ın İsa'ya hediyeler sunmasıdır.

Hıristiyan geleneğinde önemli bir yere sahip kompozisyonun kaynağında Müneccim Krallar'ın sayısı, sundukları altın, mür ve tütsü dikkate alınarak üç kişi olarak kabul edilmiştir. Jerphanion Müneccim Krallar'ın, insan yaşamının üç evresini sembolize ettiğini figürlerin yaş farklılıklarıyla açılamaktadır. Müneccimlerin sayısındaki üç kavramı, insan yaşamının üç evresini sembolize etmesinin yanında Baba, Oğul ve Kutsal Ruh olarak da kabul edilir (Jerphanion, 1925: I,78). Walker'n ifadelerini destekleyen Acharya ve Murdock, tarihsel İsa'yı bulmak için Yeni Ahit'ten Paganizm'i çıkartmak gerektiğini yazar (Acharya ve Murdock, 2011: 25).

\section{İsa'nın Doğumu Tasvirlerinde Episod Düzeni ${ }^{22}$}

Erken Dönem örnekleri üslup açısından değerlendirildiğinde figürlerin şematik ve geometrize oldukları görülür. Erken örneklerde yer alan figürlerin iri göz ve burunları, orantısız vücutları, yaş ile kimlik ayrımlarını sunan saç, sakal ve giysileri figürlerdeki üslupsal farklılıkları yansıtır. Duvar resimleri, mozaik, fildişi ve yazma

${ }^{21}$ Bu konu hakkında bakınız; (Çoşkuner,2009)

${ }^{22}$ Renklerin tanımlanması; 1.Kırmızl-Kundakta İsa, 2.Mor-Meryem, 3. Bordo-Yusuf, 4. MaviMelekler, 5. Siyah-Çobanlar, 6. Sarl-Öküz ve Eşek, 7.Krem-Müneccim Krallar, 8. BeyazBoş Sahne, 9. Kum-Ebeler, 10. Gri-Işılk Huzmesi ve Yıldız, 11. Açık Yeşil-Mimari. 


\section{Sacit Pekak-Durmuş Gür}

eserlerde 1şık-gölge, mekan, tonlama gibi kaygılardan çok ikonografik unsurlar ön plandadır.

Erken Bizans Dönemi'nde ikonografi kurallarının henüz kesinleşmediği görülür. Erken Bizans Dönemi İsa'nın doğumu tasvirleri daha çok sarkofaglar, katakomplar, enkolpionlar, ampullalar, fildişi örnekler ve madeni eserlerde görülür. Erken Dönem örneklerinde episodlar bağımsız ya da gruplar halindedir.

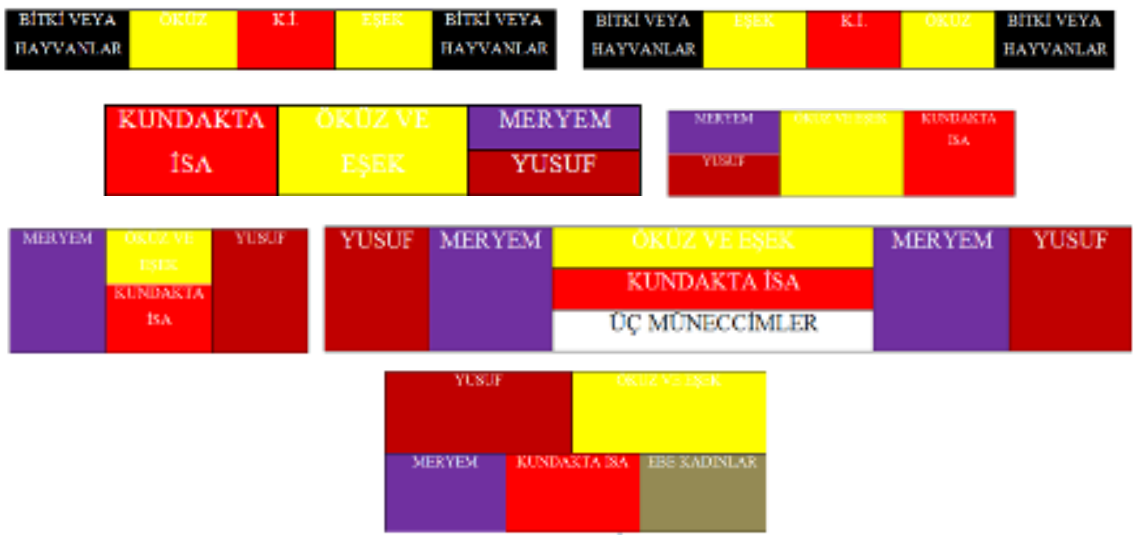

Tablo 1. 4.-6. Yüzyıl, İsa'nın Doğumu'nda Episod Düzeni

4. yüzyıl örneklerinde İsa'nın doğumu, öküz ile eşeğin tapınması episodunun işlendiği üç figürden oluşan, sade bir düzende başlayarak daha yoğun ve karmaşık bir kompozisyon halini almıştır. Atina Bizans Müzesi'ndeki kabartma ve Milano'daki Sant Amrogio Stilicon Sarkofağı buna örnektir. 4. yüzyıl örneklerinde yemlikteki kundaklanmış İsa'ya tapınan öküz ile eşek, bu tarihten itibaren kompozisyonlarda yerini almıştır (Schiller, 1971: 59) (Tablo 1).
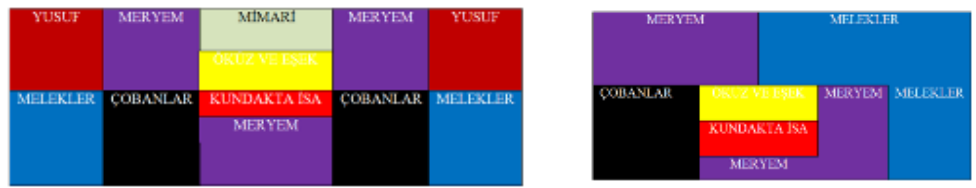

Tablo 2. 4.-7. Yüzyıl, İsa'nın Doğumu'nda Episod Düzeni

İsa'yı nefesleriyle 1sıtırken tasvir edilen hayvanlar aslında kaynaklarda doğuma şahitlik eden Melekler, Çobanlar ve Müneccim Krallar gibi tapınmanın sembolik ayrıntıları arasında kabul edilir. Ayrıca öküz ve eşek gibi kutsal hayvanlar Antik Dönem'deki mitolojik hayvan bakıcılarıyla ilişkilendirilmektedir (Schiller, 1971: 60). 3.-4. yüzyıl örneklerinde İsa yalnız başına kundakta yatarken ona sadece eşek ve öküz eşlik etmektedir. 6.yüzyılla birlikte örneklerde mağara ve Beytüllahim yıldızı, öküz ile 


\section{İsa'nın Doğumu}

eşeğin tapınması, Meryem ve Yusuf görülür. 6.yüzyılda İsa’nın ilk banyosu (ebe kadınlar tarafından banyo yaptırılması) tasvir edilmeye başladığı görülür (Tablo 2).
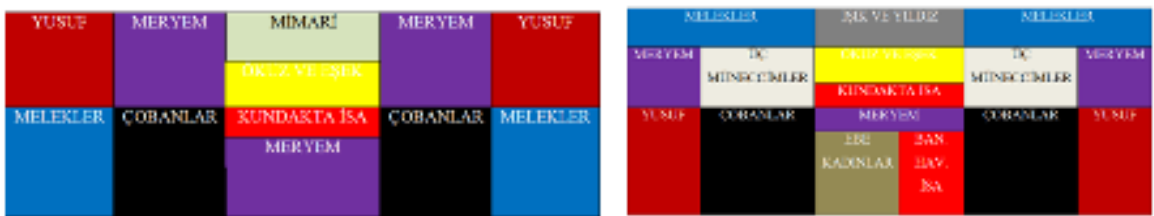

Tablo 3. 7.-10. Yüzyıl, İsa'nın Doğumu'nda Episod Düzeni

6. yüzyılla birlikte İsa'nın ilk banyosu, doğum kompozisyonlarında yerini almaya başlar. 8.yüzyıl sonrasında ise İsa'nın doğumu ya da ilk banyosu konularına ilave olarak bir meleğin çobanlara İsa'nın doğumunu müjdelediği görülür. Çobanlara meleğin müjdesi, doğum sahnesine sonradan giren episodlar arasındadır. Episodda anlatılan, Çobanlar, müjde veren melek ve yanında melekler ordusu Bizans sanatı için ikonografik veri oluşturur. Bununla birlikte çobanların sayısı, duruşları, yerleri ve sürüleri belirtilmez. Çobanlar Beytüllahim'e ulaştıklarında doğum gerçekleşmiş ve bebek İsa yemlikte yatmakta, çobanlara melek müjde vermektedir. Luka'da ayrıntılarıyla sunulan episodda çobanların sayısı belirtilmemektedir. Ayrıca, müjdenin bir melek aracılığıyla çevredeki çobanlara bildirildiği anlatılır (Tablo 3-4).
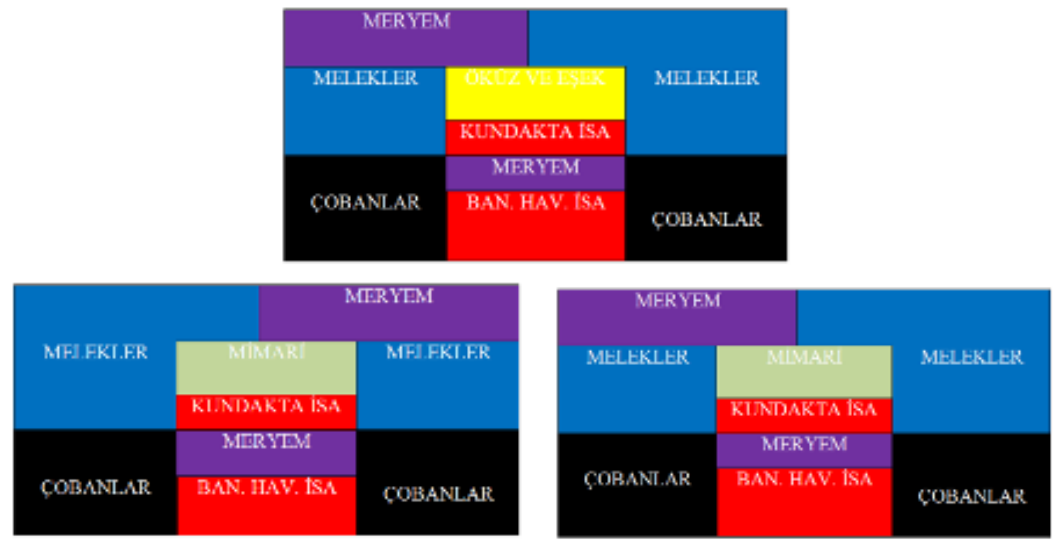

Tablo 4. 7.-10. Yüzy1l, İsa'nın Doğumu'nda Episod Düzeni ${ }^{23}$

\footnotetext{
${ }^{23}$ 6.yüzyıldan itibaren kompozisyonların sol ya da sağ bölümlerindeki boş olarak tanımlanan bölümlerde çoğunlukla Müneccim Krallar'ın isaya hediyeler sunmasi/secdesi görülür. Episod düzenlemelerinde yoğunluk olması sebebiyle sadece boş olarak ifade edilmiştir. Müneccim Krallar için bakınız: (Wilhelm-Red, 1994: 86-120).
} 


\section{Sacit Pekak-Durmuş Gür}

9. ve 10. yüzyılda, İsa'nın doğumu tasvirlerinde çeşitli değişimler görülür. Yıldız, mağara, yemlik, öküz, eşek, Meryem, Yusuf, ilk banyo ve ebe kadınlar, meleğin çobanlara müjdesi, çobanların doğuma şahitlik etmesi, Müneccim Krallar'a yıldızın yol göstermesi ve Müneccim Krallar'ın tapınması tasvirlerde bazen bir arada bazen ayrı ayrı görülmektedir.

9. ve 10. yüzyıl sonrasında kompozisyonlarda büyük değişim görülmez. Genellikle kompozisyonun merkezindeki Meryem ve İsa'nın çevresine farklı figürler eklenir-çıkartılır. 9.-10. yüzyıl Metropolitan Museum'da bulunan Fieschi-Morgan rölikeri ve Sofya Arkeoloji Müzesi'ndeki Pliska Enkolpionu'nda görülen kompozisyon, gelişen ikonografinin göstergesidir (Kartsonis, 1986: Res. 24,26a-b)(Tablo 5-6).
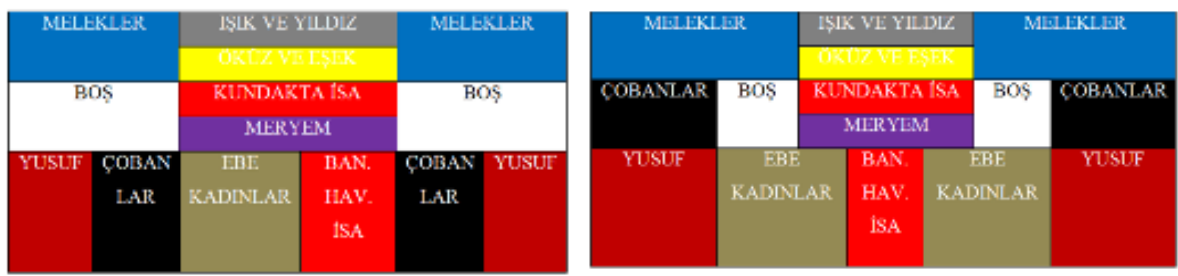

Tablo 5. 10.-13. Yüzy1l, İsa'nın Doğumu'nda Episod Düzeni
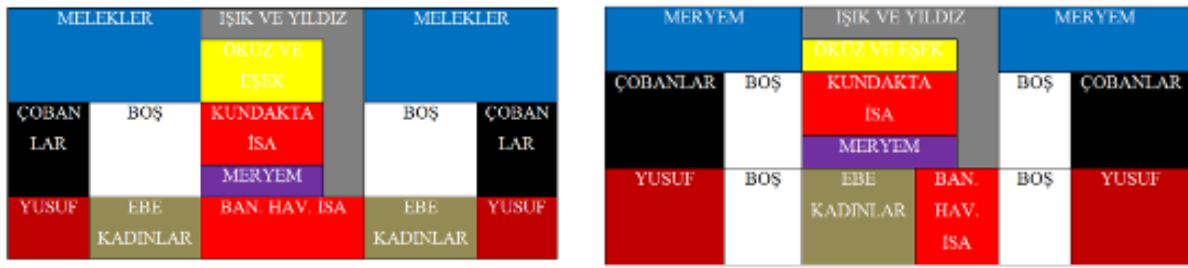

Tablo 6. 14.-20. Yüzyıl, İsa'nın Doğumu'nda Episod Düzeni

10. yüzyıl ve sonrasına tarihlendirilen İsa'nın doğumu tasvirlerinde, figürlerin Erken Dönem örneklerine oranla daha dengeli ve ölçülü oldukları görülür. 11. yüzyılın ortalarından itibaren tasvirlerde realist uygulamalar görülür. Farklı duygusal durum ve karakterler figürlerin fizyonomileriyle ifade edilir. Figürler bedensel ağırlık ve hareket katan duruşlar, derin bakışlarıyla akıcı hareketleri doğum kompozisyonlarının ortak özelliğidir. $\mathrm{Bu}$ uygulamalar 11. ve 17. yüzyıl arasına tarihlendirilen Avrupa örneklerinde daha belirgindir ${ }^{24}$.

Bizans Dönemi'nde çok sayıda tasvir edilen İsa'nın doğumu, Modern sanatta çeşitli resim ve heykellerde yerini alır. Kısaca açıklamak gerekirse, İsa'nın doğumu, günahların ölümü olarak kabul edilir. Tasvirlerde meşrulaştırılmaya çalışılan bu inanış, İsa'nın doğumu ve çarmıha gerilişi kompozisyonlarının bir arada kullanılmasıyla

${ }^{24}$ 13-18. yüzyıl Avrupa örnekleri için bakınız; (Wilhelm-Red, 1994: 107-118). 
açıklanabilir. Kiliselerde doğum ve çarmıh tasvirlerini yan yana ya da karşılıklı görmek mümkündür. Kappadokia kiliselerinde karşılıklı işlenmiş birçok yapı mevcuttur. Ayrıca müzelerdeki enkolpion, fildişi, atlar panoları, pyxis ve çeşitli metal örneklerde doğum ve çarmıh tasvirlerini bir arada görmek mümkündür.

\begin{tabular}{|c|c|c|c|c|c|c|c|c|c|}
\hline $\begin{array}{l}\text { İsa'nın } \\
\text { Doğumu }\end{array}$ & Çobanlar & Müneccimler & Mekan & Ebe/Ler & Yemlik & Yıldız/lşık & Zaman & Öküz & Eşek \\
\hline Matta & - & + & meryem'in evi & - & & (yıldız) & - & - & - \\
\hline Luka & + & - & han & - & + & (yıldız) & - & - & - \\
\hline $\begin{array}{l}\text { İokabos } \\
\text { İncili }\end{array}$ & - & + & mağara/ahır & $\begin{array}{c}+ \\
\text { (salome) }\end{array}$ & + & (yıldız) & - & + & + \\
\hline $\begin{array}{l}\text { Barnabas } \\
\text { İncili }\end{array}$ & - & + & mağara/han & - & + & (yıldız) & - & - & - \\
\hline $\begin{array}{l}\text { İsa'nın } \\
\text { Çocukluk } \\
\text { İncili }\end{array}$ & + & - & mağara & $\begin{array}{c}+ \\
\text { (salome) }\end{array}$ & - & (Işı) & $\begin{array}{l}\text { gün } \\
\text { batmak } \\
\text { üzereydi }\end{array}$ & - & - \\
\hline $\begin{array}{l}\text { Pseudo- } \\
\text { matta }\end{array}$ & - & bilge & mağara/ahır & $\begin{array}{c}+ \\
+ \\
\text { salome/ } \\
\text { zelami }\end{array}$ & + & (Ișık) & $\begin{array}{c}\text { gün } \\
\text { batmış̧ı }\end{array}$ & + & + \\
\hline
\end{tabular}

Tablo 7. Kanonik ve Apokrif Kaynaklarda İsa'nın Doğumu ve Episodlar

\section{KAYNAKLAR}

Acara, Meryem. (1998). "Bizans Ortodoks Kilisesinde Litürji ve Litürjik Eserler", Hacettepe Üniversitesi Edebiyat Fakültesi Dergisi, C.15, S.1, Ankara, 183201.

Acharya, S. ve Murdock, D.M. (2011). The Origins of Christianity and the Quest for the Historical Jesus Christ, www.StellarHousePublishing.com.

Akalın, Kürşat Haldun. (2014). "Yunan-Roma Uygarlığında İnsan-Tanrılara Tapınma Töreni Olarak: Kilise Ekmek-Şarap Ayini”, Atatürk Üniversitesi Ilahiyat Fakültesi Dergisi, S.41. 129-160.

And, Metin. (1998). Minyatürlerle Osmanl-İslam Mitologyast. İstanbul: Akbank Kültür ve Sanat Kitapları.

Anonim. (2002). Bilble Atlas Access Foundation (Edit.: Zaine Ridling). Part 3, Chapter 21. Bask1 Yeri Belirtilmemiştir.

Arad, Lily. (2003). " The Bathing of The Infant Jesus in The Jordan River And His

Baptism in a Font: A Mutual Iconographic Borrowing In Medieval Art”, Miscellània Litúrgica Catalana. 21-44.

Bardill, Jonathan. (2010). “IX. Konstantinopolis Hipodromu'nun Anitları ve Süslemeleri”, Hipodrom/Atmeydanı İstanbul'un Tarih Sahnesi. İstanbul: Pera Müzesi. 149-184. 
Bell, Malcolm. (1979). "Mosaic of The Birth of Achilles", Age of Spirituality Late Antique and Early Christian Art Third to Seventh Century (Edit.: Kurt Weitzmann). New York: Princeton University Press. 237-238.

Boormans. P. (2005). "İncilde Mesih İsa", Uluslararasl Müslüman-Hıristiyan Diyalog Sempozyumu II (İslam ve Hiristiyan Kaynaklarında Hz. İsa) (23-24 Eylül 2005). İstanbul. 40-68.

Brown, Katharine Reynolds. (1979). "Medallion With Virgin and Child enthroned", Age of Spirituality Late Antique and Early Christian Art Third to Seventh Century (Edit.: Kurt Weitzmann). New York: Princeton University Press. 312-313.

Blank, Hanne. (2008). Bekaretin El Değmemiş Tarihi, (Çev. Emek Ergün). İstanbul: İletişim Yayınları.

Carr, A. W. ve Kazhdan, A. (1991). "Nimbus", The Oxford Dictionary of Byzantium, 2. New York: Oxford University Press. 1487.

Carr, A. W. ve Kazdhan, A. (1991). "Protoevangelion in James" The Oxford Dictionary of Byzantium, 3. New York: Oxford University Press. 1744-1745.

Carr, A. W. (1991) "Representation in Art (Virgin Mary)", The Oxford Dictionary of Byzantium, Vol.3. New York: Oxford University Press, 2174-2175.

Cartlidge, D. R. ve Elliot, J. K. (2001). Art and the Christian Apocrypha. London: Routledge.

Chadwick, Henry. (1980). Origen Contra Celsum. London: Cambridge University Press.

Coomaraswamy, Ananda K. (1916). Buddha and the Gospel of Buddhism. New York: Harper and Row Publishers.

Cosaert, Carl. (2008). Cosaert the Text of the Gospels in Clement of Alexandria New Testament in the Greek Fathers. Atlanta: Society of Biblical Literature.

Coşkuner, Buket. (2009). 11. Yüzyılda Kappadokia Bölgesi'ndeki İsa'nın Doğumu ve İsa'nın Çarmıha Gerilmesi Sahneleri. Hacettepe Üniversitesi Sosyal Bilimler Enstitüsü Yayınlanmamış Doktora Tezi). Ankara: Hacettepe Üniversitesi.

Crowe J. A. ve Cavalcaselle G. B. (1914). A History of Painting in Italy. Vol. VI. Sienese and Florentine Masters of The Sixteenth Century. London John Murray Albemarle Street.

Doğan, Sema. (2010). “Antalya Arkeoloji Müzesi’nde Bir Levha ve Bizans Kiliselerinde Başmelek Gabriel İmgesi”, İslam ve Hıristiyan Sanatında Melekler, Peygamberler ve Azizler/Angels, Prophetsand Saints in Islamic and Christian Art (Edit.: S. Yandım Aydın). İstanbul. 171-184. 
Eski Ahit (2015). Kutsal Kitap (Eski Ahit, Zebur, Yeni Ahit), İstanbul: TKK.

Frazer, Margaret E. (1979). "Holy Sites Representations", Age of Spirituality Late Antique and Early Christian Art Third to Seventh Century (Edit.: Kurt Weitzmann). New York: Princeton University Press.564-568.

Gombrich, E.H. (1980). Sanatın Öyküsü (Çev. Bedrettin Cömert), İstanbul: Remzi Kitabevi.

Hild, F. ve Restle, M. (1981), Kappadokien (Kappadokia, Charsianon, Sebasteia und Lykandos), Tabula Imperii Byzantini I.-II. Wien: Verlag der Österreichischen Akademie der Wissenschaften.

Jaszai, G. (1994). "Geburt Mariens", Lexikon der Christlichen Ikonographie Algemenia Ikonographie F-K 2 (Herausgegeben von Engelbert Kirschbaum sc in Zusammenarbeit Mit Günter Bandmann, Wolfgang Braunfels, Johannes Kollwitz, Wilhelm Mrazek, Alfred A. Schmid, Hugo Schnell), Germany: Herder. 120-125.

Jerphanion, Guillame. (1925). Une Nouvelle Provence de l'art Byzantien: les Eglises Rupestres de Cappadoce I. Paris.

Kalavrezou, Ioli. (2005). "Exchanging Embrace. The Body of Salvation", Images of the Mother of God. Perceptions of the Theotokos in Byzantium. (Ed. M. Vassilaki) Ashgate. 103-117.

Kalokyris, Constantine D. (1969). The Star of Bethlehem in Byzantine Art (Iconographic Interpretation). Thessaloniki.

Karpozilos, A. ve Kazhdan, A. ve Cutler, A. (1991). "Birth", The Oxford Dictionary of Byzantium I. Oxford University Press. 290-291.

Kartsonis, Hanna. (1986). Anastasis, The Making of an Image, Princeton University Press.

Kazhdan, Alexander ve Sevcenko, Nancy Patterson. (1991). "Maphorion," Dictionary of Byzantium, Vol. 1. Oxford: Oxford University Press. 1294.

Kennett, Jiyu. (1972). Selling Water by the River: A Manuel of Zen Training. New York: Pantheon Books.

Kessler, Herbert L. (1979). "Narrative Representations", Age of Spirituality Late Antique and Early Christian Art Third to Seventh Century (Edit.: Kurt Weitzmann). New York: Princeton University Press. 449-456.

Kouymjian, Dickran. (2012). "Did Byzantine Iconography Influence the Large Cycle of the Life of Alexander the Great in Armenian Manuscripts?", Byzajhıum Renaissances Dialogue of Cultures, Heritage of Antiquity Tradition and Modernity, (Edit.: Michala Janochy, Aleksandry Sulikowskiej, Iriny Tatarovej oraz Zuzanny Flisowskiej, Karoliny Mroziewicz, Niny i Krzysztofa Smôlskich). Warsaw: University of Warsaw. 209-216, Fig. 61-70. 
Kitzinger, Ernst. (1963). "The Hellenistic Heritage in Byzantine Art", Dumbarton Oaks Papers, 17. 97-115.

Koukoules, P. (1948-1957), Byzantinôn bios kai politismos: Vie et Civilisation Byzantine, Vol. 6. Athènes: Institut Français d'Athènes.

Lafontaine-Dosogne, J. (1975). "Iconoraphy of the Cycle of the Infancy of Christ" The Kariye Djami, IV. (Edit.: P. Underwood). New-Jersey.

Lazarides, Paul. (1987). The Monastery of Hosios Lukas: Brief Illustrated Archaeological Guide. Athens: Hannibal Publishing.

Macdonald, W. (2000). Kutsal Kitap Yorumu. Yeni Antlaşma Serisi, I-II. İstanbul: Yeni Avrasya Yayınları.

Maguire, Henry. (1977). "The Depiction of Sorrow in the Middle Byzantine Art" Dumbarton Oaks Papers, 31, 123-174.

Maguire, Henry. (1996). "Image and imagination: the Byzantine epigram as evidence for viewer response". Toronto: Canadian Institute of Balkan Studies, 25. 1-25.

Borg, Marcus. (1999). "The Meaning of the Birth Stories" The Meaning of Jesus: Two Visions (Edit.: Marcus J. Borg, N.T. Wright) San Francisco: Harper. 179-186.

Martin, John R. (1955). "The Dead Christ on the Cross in Byzantine Art", Late Classical and Merdiaeval Studies in Honour of Albert Mathias Friend, Jr. (Edit.: Kurt Weitzmann). Princeton. 189-196.

Mark D. Roberts. (2007). Can We Trust the Gospels?. Printed in the United States of America.

Oldenberg, Hermann. (2006). Le Bouddha: sa vie, sa doctrine, sa communauté. Chicoutimi, Québec.

Olszewski, Marek T. (2013). "The iconographic programme of the Cyprus mosaic from the House of Aion reinterpreted as an anti-Christian polemic", Studia Memoriae. Warsaw: Institute of Archaeology, University of Warsaw. 207239, Pls. LXXIV-LXXXVI.

Ongun, Cemil Sena. (1941). Buda ve Konfüçyüs. İstanbul: Tefeyyüz Kitabevi.

Osborn, Eric. (1957). The Philosophy of Clement of Alexandria. London: Cambridge University Press.

Önen-Alev, Ayten. (2014). Kappadokia Göreme Vadisi’nde Meryem Siklusu, Hacettepe Üniversitesi Sosyal Bilimler Enstitüsü Sanat Tarihi Anabilim Dalı (Yayınlanmamış Yüksek Lisans Tezi). Ankara.

Ötüken, S. Yıldız. (1984). “Kapadokya Bölgesi'ndeki Kapalı Yunan Haçı Kiliselerde Resim Programı”, Arkeoloji ve Sanat Tarihi Dergisi 3. 143-167. 
Palli, Lucchesi E. (1994). "Liturgie, Hİmmlische", Lexikon der Christlichen Ikonographie Algemenia Ikonographie L-R 3 (Herausgegeben von Engelbert Kirschbaum sc in Zusammenarbeit Mit Günter Bandmann, Wolfgang Braunfels, Johannes Kollwitz, Wilhelm Mrazek, Alfred A. Schmid, Hugo Schnell), Germany: Herder. 103-106.

Raquel, Maria Isabel. (2013). “O Menino de Belém: Da Festa do Natal à Iconografia da Natividade e da Adoração”, Gaudium Sciendi, 5, Dezembro, 104-126.

Restle, M. (1967). Byzantine Wall Paintings in Asia Minor I-II-III. Irish University Press.

Ruben, Walter. (2000). Eski Metinlere Göre Budizm: Budacılı̆̆ın Diyalektik Yorumu (Haz. Lütfü Bozkurt). İstanbul: Okyanus Yayınları.

Sach, Hannelore ve Badstübner, Ernst ve Neumann, Helga. (1988). Christliche Ikonographie in Stichworten. Leipzig: Koehler \& Amelang.

Salvador-Gonzalez, Jose Maria. (2012). "Iconografía de La Adoración de los pastores en la pintura italianabajomedieval. Una mirada bucólica a la existencia del pobre", Eikon/İmago 1,1-38.

Sanders, E. P. (1995). The Historical Figure of Jesus. Penguin UK.

Schiller, Gertrud. (1972). Iconography of Christian Art, Volume 2. New York.

Sinkevic, Ida. (2000). The Church of St. Panteleimon at Nerezi, Architecture, Programme, Patronage, Reichert Verlag Wiesbaden.

Spitzing, Günter. (1989). Lexikon Byzantinisch-Christlicher Symbole. Köln: Eugen Diederichs.

Sunay, Serkan. (2012). "Erken Hristiyan ve Bizans Sanatında Hâle”, Ekev Akademi Dergisi, Y. 16/S. 50. 197-213.

Tanburoğlu, N. (2001). Kapadokya Bölgesi Göreme Vadisinde Bulunan Karanlık Kilise Duvar Resimleri, Hacettepe Üniversitesi Sosyal Bilimler Enstitüsü (Yayınlanmamış Yüksek Lisans Tezi), Ankara.

Taft, R. F.ve Carr, A. W. (1991a). "Announciation", The Oxford Dictionary of Byzantium I. New York: Oxford University Press. 106-107.

Taft, R. F.ve Carr, A. W. (1991b). "Dormition", The Oxford Dictionary of Byzantium I, New York: Oxford University Press, 651-653.

Tritsaroli, P. ve Valentin, F. (2008). "Byzantine Burials Practices for Children; Case Studies Based On A Bioarchaeological Approach To Cemeteries From Greece", Nasciturus, Infans, Puerulus Vobis Mater Terra: la Muerte en la Infancia, (Edit.: Gusi Jener, F., Muriel, S. and Oläria, C.). La Rioja: Diputacio de Castello. 83-113. 


\section{Sacit Pekak-Durmuş Gür}

Thierry, Nicole. (1963). The Rock Churches, Art of Cappadocia. Geneva: Negal Publishers.

Weitzmann, Kurt. (1951). The Fresco Cycle of S. Maria di Castelseprio, Princeton: Princeton Universty Press.

Weitzmann, Kurt. (1974). "Loca Sancta and the Arts of Palestine", Dumbarton Oaks Papers, 28. 32-55.

Vermes, Géza. (2006). The Nativity: History and Legend. Penguin Books.

Vikan, Gary (2003). Sacred Images and Sacred Power in Byzantium. Variorum Collected Studies, Hampshire.

Wilhelm-Red, P. (1994). "Geburt Christi”, Lexikon der Christlichen Ikonographie Algemenia Ikonographie F-K 2 (Herausgegeben von Engelbert Kirschbaum sc in Zusammenarbeit Mit Günter Bandmann, Wolfgang Braunfels, Johannes Kollwitz, Wilhelm Mrazek, Alfred A. Schmid, Hugo Schnell), Germany: Herder. 86-120.

Yeni Ahit. (2012). Yeni Ahit (Müjde Yeni Ahitin Çă̆daş Türkçe Çevirisi), İstanbul: TKK.

Yılmaz, Sinan. (2015). Paganizm'den Hıristiyanliğa Geçmiş Semboller (I. ve V. Yüzyıllar Arası), Cumhuriyet Üniversitesi Sosyal Bilimler Enstitüsü (Yayınlanmamış Yüksek Lisans Tezi). Sivas. 